Fall 1933

\title{
1933 Cedrus Yearbook
}

\section{Cedarville College}

Follow this and additional works at: https://digitalcommons.cedarville.edu/yearbooks

Part of the Higher Education Commons, Organizational Communication Commons, and the Public Relations and Advertising Commons

\section{Recommended Citation}

Cedarville College, "1933 Cedrus Yearbook" (1933). Yearbooks. 79.

https://digitalcommons.cedarville.edu/yearbooks/79

This Book is brought to you for free and open access by DigitalCommons@Cedarville, a service of the Centennial Library. It has been accepted for inclusion in Yearbooks by an authorized administrator of DigitalCommons@Cedarville. For more information, please contact digitalcommons@cedarville.edu. 
che cedrus 


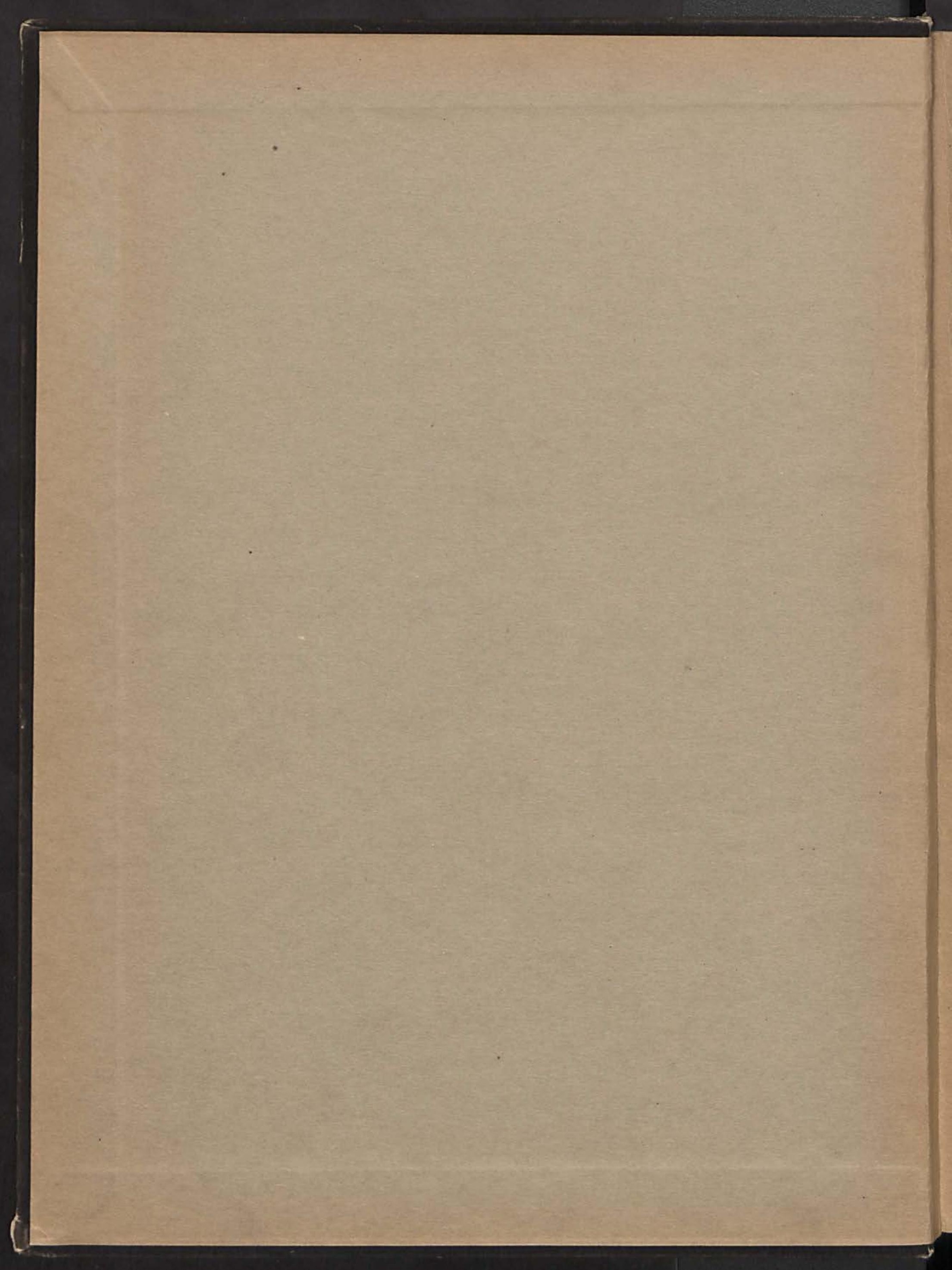





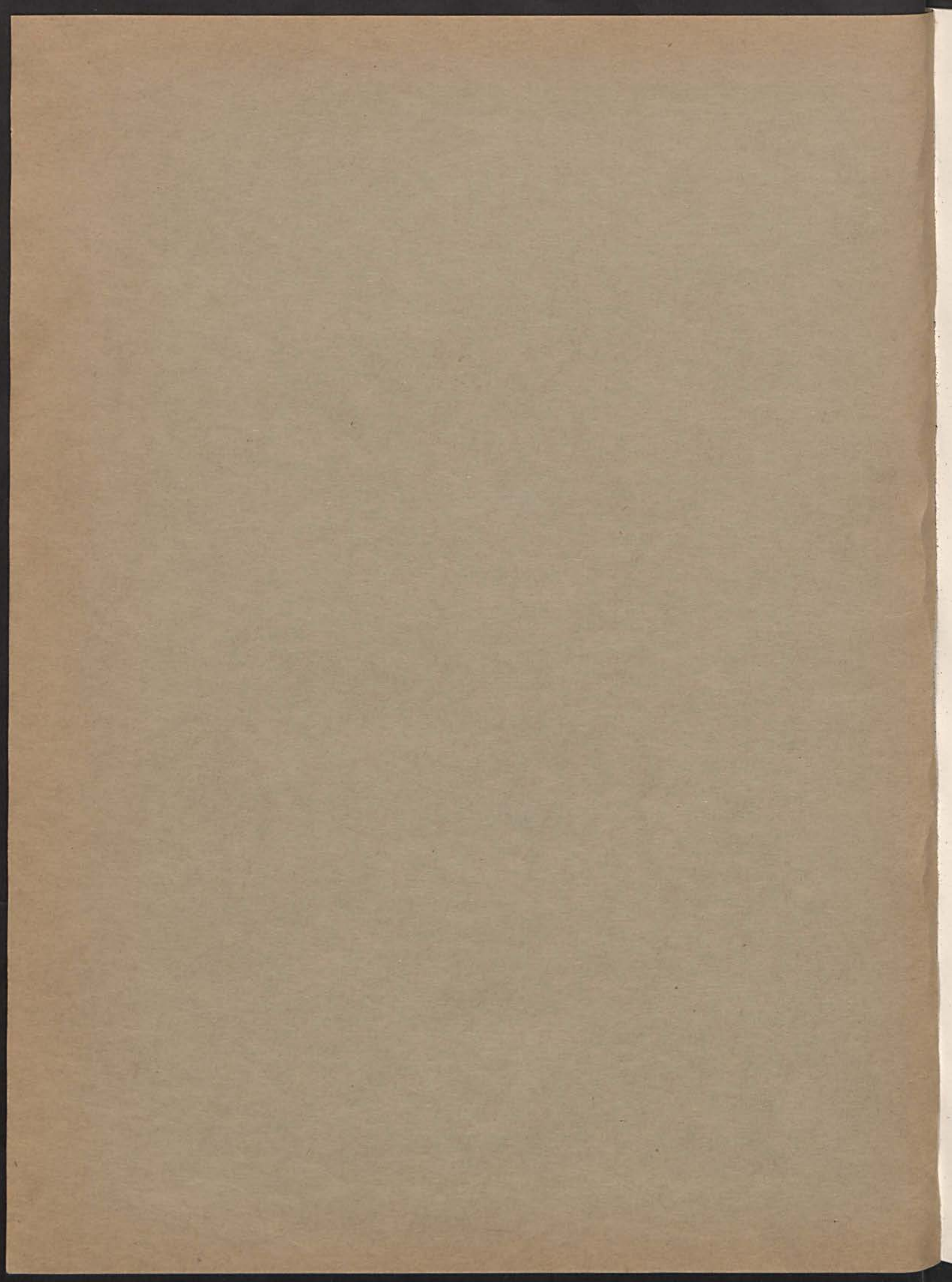




\title{
THE CEDRUS
}

EDITED BY STUDENTS OF

\section{CEDARVILLE COLLEGE}

\author{
$\checkmark$ \\ Nam et ipsa scientia potestas est. \\ Knowledge is power.
}




\title{
PREF A CE
}

\begin{abstract}
$T$
HERE lie at every man's disposal vast reservoirs of power, which he must needs convert to useful ends, if he wishes to attain some worthwhile goal, and truly to serve mankind to the best of his ability. These powers are manifold; they lie in the realms of the physical, mental, and spiritual.

Preeminent among these powers is knowledge, basic to the highest development of man's physical and spiritual natures. This source of power is placed within our reach in many forms, but perhaps it presents itself to all of us most often through the written experiences of others, as recorded in books.

We have endeavored this year to create a publication that can truly be called a book. To this purpose we have presented several essays and compositions, contributed by members of the student body, as well as portrayed the life of the school in a literary form.

We most sincerely appreciate the cooperation of all those who have helped us in the production of this book; especially those who have contributed articles and have aided in the compiling of the contents of this volume, and the ones who have assisted in the editing and typing of the manuscript.
\end{abstract}


THE CEDRUS 
MIAMI VALLEY PUBLISHING CO., Printers

PONTIAC ENGRAVING CO., Engravers

SCHREEL STUDIOS, Photographers 


\section{CONTENTS}

CHAPTER ONE

CHAPTER TWO

CHAPTER THREE

CHAPTER FOUR

CHAPTER FIVE
LAW AND GOVERNMENT

LITERATURE AND MUSIC

SCIENCE

VOCATIONS

CHARACTER 


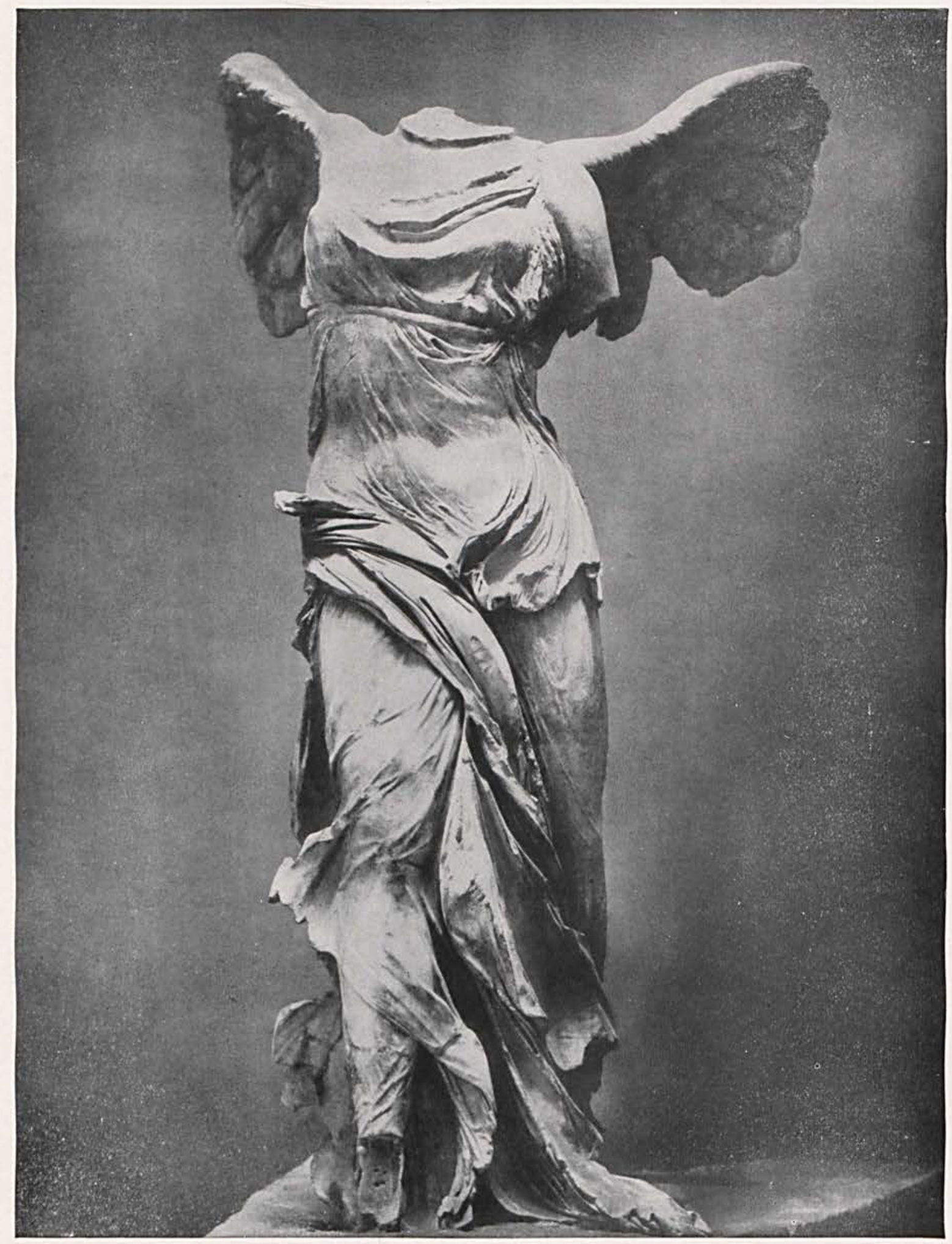




\title{
CHAPTER ONE
}

\section{Law and Government}

\begin{abstract}
VICTORY OF SAMOTHRACE
The Victory of Somothrace is one of the most sublime expressions of movement left to us by antique art. The irresistible energy, the victorious swing of the body, and the muscular strength and triumphant grace seem to animate the marble.

The Winged Victory was carved to commemorate a naval victory of the Greeks over the Egyptians in the fourth century B. C. The figure originally stood on the prow of a galley, blowing a trumpet. The statue now stands in the Louvre at Paris.
\end{abstract}

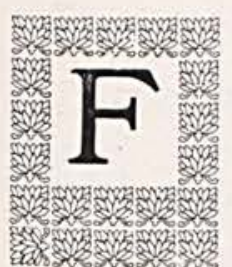

ROM time immemorial, the spirit of man, born free, has everywhere been in chains. Through these social institutions, as we call them, are conserved to future generations the contributions of bygone ages; without them, social life would be disintegrated and unstable. Social order is a sacred right which serves as a basis for all others.

This social order is maintained by laws, the arbitary rules established by governments. Again, law is "that portion of the established thought and habit which has gained distinct and formal recognition in the shape of unif orm rules backed by the authority and power of government." And government itself is, in its widest sense, the ruling power in a political society. It rests on the fundamental idea of control and obedience; it implies authority and a submission to that authority.

So far as we know, government, with its attendant laws of one form or another, has existed from the first population of the world. We are told in legendary tales that Sparta's government was devised by Lycurgas; that Moses, Numa, and Alfred the Great in like manner shaped the government of their respective nations. But from time to time throughout history's pages, we find men, who, dissatisfied with mere legend, have attempted to find a metaphysical basis for the right to establish governments and enact statutes.

First was the theological view, that power has been divinely delegated to the State. Next, the Church, objecting, set itself up as the only divinely ordained institution, and 


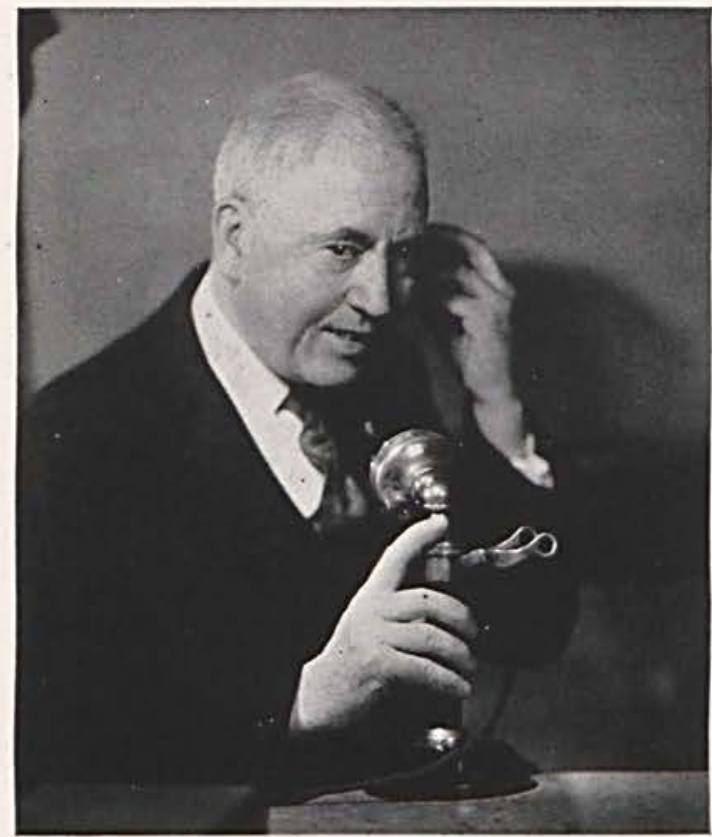

W. R. MeCHESNEY

President: Peter Gibson Professor of Philosophy and Greek: A. B. Franklin College: A. M. Franklin College Ph. D. Franklin College; D. D. Tarkio College.

therefore as superior to the State. Dante tried to coordinate the views; Macchiavelli insisted upon complete severence of State and Church. Spinoza said might makes right; not until 1918 was the world convinced of the falsity of this notion. The Analycists ascribed to the words of the legal statutes themselves a certain inherent right to rule-a certain "legal fibre." Rousseau's SocialContract theory, of French Revolutionary times regarded the individual as the possessor of certain inalienable rights which can be surrendered only upon the guaranty of other beneficial duties to be performed by the State. Today, we believe that the basis of soyereignty rests not upon any artificial compact, but upon the solidarity which characterizes the common consciousness of men. "This forms a natural foundation, and its expression in sovereign law is a natural manifestation."

Twenty-two centuries ago, the first great political scientist, Aristotle, classifed the forms of government by the numerical relation between those in power and their constituency. The government may be a monarchy, governed by one; an aristocracy governed by a very few in proportion to the whole population; or a democracy, governed by many. In general, this classifiction still holds good today.

Aristotle further divided governments according to an ethical concept, asking the question, does the governing power seek to its own advantage, or to the advantage of the whole people? The answer to this question gives us not three, but six varieties of government, for each perfect form has a corresponding depraved form.

The good government of one (Monarchy) is contrasted with the depraved form (Tyranny) ;

The good government of a few (Aristocracy) is contrasted with the depraved form (Oligarchy) ;

The good government of many (Democracy) is contrasted with the depraved form (Anarchy).

Human frailties have permitted the establishment of a veritable law concerning the recurrent cycle of changes through which a normal government passes. First, it is Monarchy, under a single strong man with sovereign power. Handed down to his children, it in time degenerates to Tyranny, as they forget his wise precepts. At some Runnymede, revolt occurs, and a princely few, public-spirited in their aims, set up an Aristrocracy. This early justness in an Aristrocracy always declines in the years of its dotage into selfish Oligarchy. Oligarchy, fatal to civil liberty, goads the people to revolution, with a Democracy as its almost inevitable result. Even Democracy has its old age of degeneracy-an old age in which it loses its early respect for law, and its first amiability of mutual concession. License and Anarchy break out, and only a Caesar can bring it back to reason and order. Thus the cycle is completed, and the state is once more back at the job of cutting its legislative teeth.

Our brief study here can only mention the problem that is perhaps the most fascinating of all: what shall be the sphere of government? To what limits shall the government's powers extend? 
This problem resolves itself into the relative advisability of a policy of laissezfaire or one of mercantilism. Shall the government keep out of business altogether, or shall it enter into the economic life whenever it deems it necessary? The former leads to an anarchical state; the latter, carried to its logical conclusion, ends in Socialism. Obviously, the trend in the United States is toward a modified Socialization of economics; the Interstate Commerce Commission, the present banking reforms, government subsidizing of marine and air transportation, government regulation of power, light, and gas rates, all point strongly to a decreased fear of executive and legislative powers. Whether this be good or bad, it is fully in accord with our previously-described cycle of government.

From this study, then, of the science of government-its origin, its forms, its rights and powers-we draw three conclusions. In the words of Woodrow Wilson,

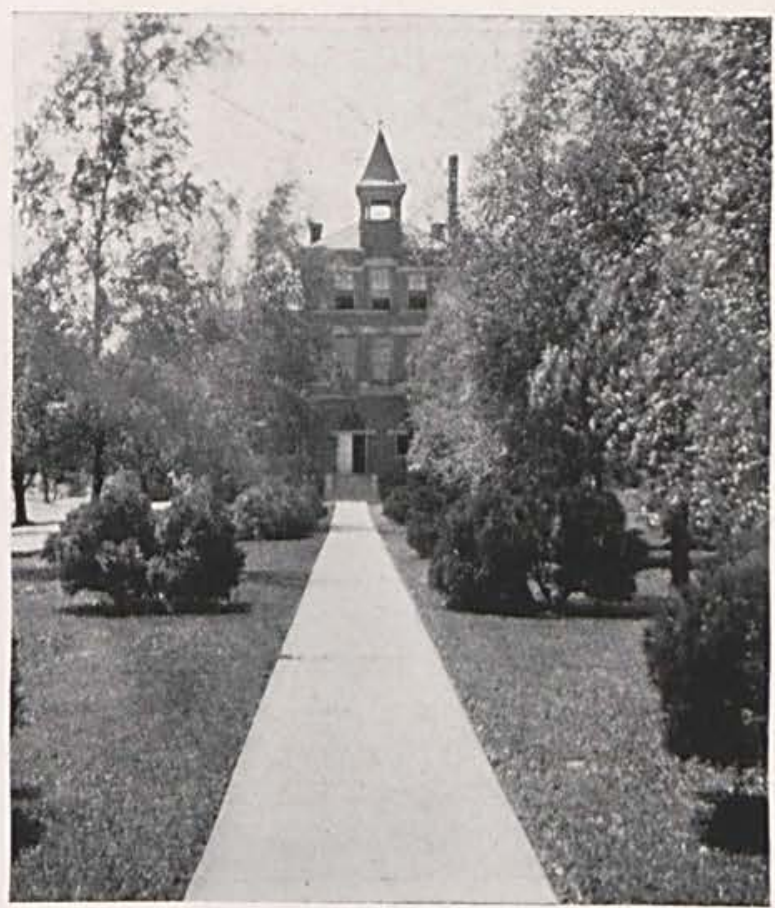

OLD MAIN "The end of government is the facilitation of the objects of society. The rule of governmental action is necessary cooperation. The method of political development is conservative adaptation, shaping old habits into new ones, modifying old means to accomplish new ends."

-Walter S. Kilpatrick.

\section{History}

Agitation for a Reformed Presbyterian College was inaugurated at the General Synod of the Church, May, 1879, by the Rev. J. F. Morton, D. D. Upon the acceptance of
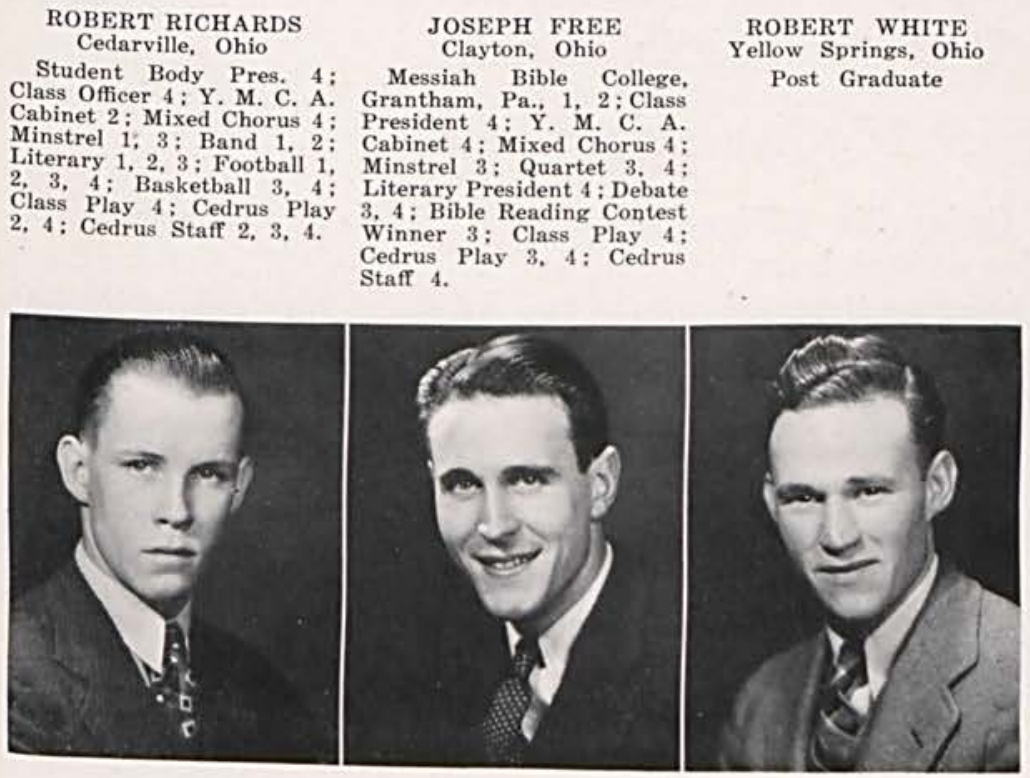

a motion to this effect, a committee, with Dr. Morton as chairman, was appointed to carry out the project. At various subsequent meetings of the General Synod, further action was taken, but the lack of funds prevented the immediate opening of such an institution. A committee was appointed in 1885 to secure a site for the college at or near Cedarville, Ohio. Seven years later, several large donations made possible further consideration of the project, and in September, 1894, Cedarville College was opened with a faculty of 6 and a student body of thirty-six. 


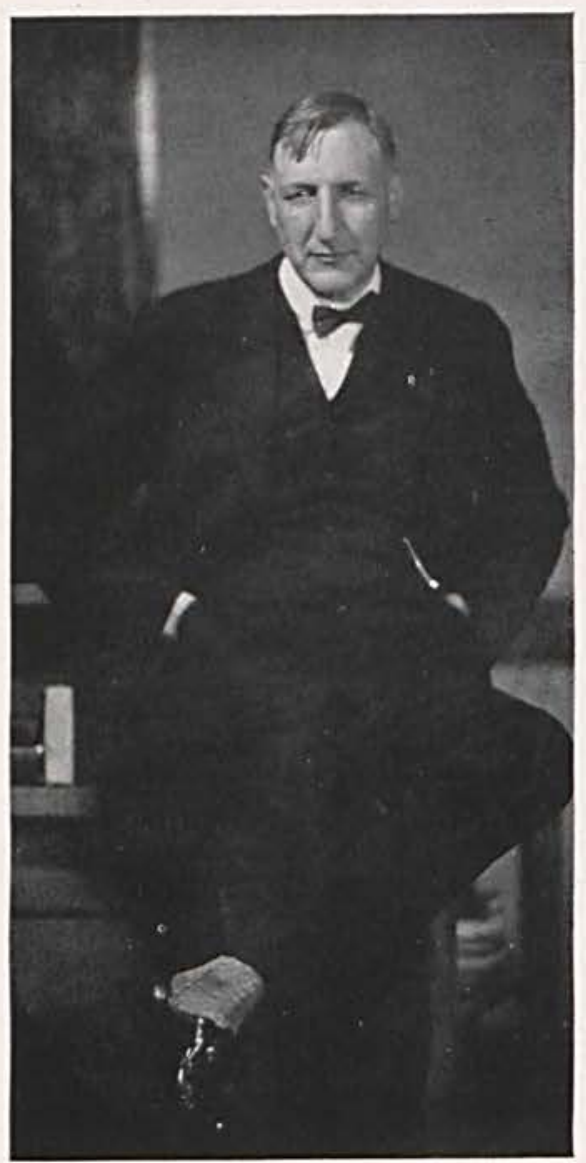

F. A. JURKAT

Treasurer; Professor of Languages and History, A. B. Franklin College: A. M. M. Wittenberg College; Ohio State University.

The college was first housed in the fine old mansion formerly belonging to Dr. Hugh McMillan, the first pastor of the Main Street Reformed Presbyterian congregation of Cedarville. Half a century earlier, Dr. McMillan had taught an academy in this same building. These quarters proving too limited, construction of the new building on the main campus was begun, and its dedication occurred during the meeting of Synod, 1896.

Rev. David McKinney, D. D., chosen as the first President, served in this capacity until 1915, a period of twenty-one years. Upon his resignation, Dr. McChesney was elected as his successor.

In 1913, the Theological Seminary of the Reformed Presbyterian Church was moved to Cedarville from Philadelphia. It is one of the oldest instiutions in the United States for the professional training of young men for the Gospel ministry. It has been in operation now for nearly a century and a quarter, with two brief intermissions.

In 1928, the General Synod by a unanimous vote gave full ownership and control of Cedarville College to the Board of Trustees of the College; however, the Seminary has been continued in affiliation with the Col. lege proper.

Five hundred graduates have passed from Cedarville's halls of learning and no more fitting testimonial to the value of the school could be imagined than their useful Christian lives in all parts of the United States and the world.

Cedarville College's supreme ideal is to guide its students into the truth in all matters; and with a goal like this, the institution promises an even more brilliant future than has been its past.

\section{Dr. McChesney}

For nearly two-score years, Cedarville College has been a living and growing monument to the sacrificing faithfulness of that $b$ and of men and women who have made it possible. Very, very close to the head of that list comes the name of the man who has been affiliated with the institution from its birth, whose life-work and hopes are so tied up in the work and hopes of the College that mention of the one automatically calls to mind the other-President W. R. McChesney.

Dr. McChesney is known throughout much of the United States as an inspirational teacher and minister and a wonderful orator. Every student in the College's history has come under his influence in such vital courses as psychology, philosophy, logic, ethics, and so forth. One desiring to pursue the study of Greek in another school could give no higher reference than a transcript of Greek credits under Dr. McChesney.

Dr. Mac's personality and prestige does much toward keeping the enrollment of the college up to its normal size-even to the extent of housing an annual collection of Illinois relatives in his home. 


\section{Dr. Jurkat}

Ever since the second year of the College's establishment, Dr. Jurkat has been an indispensable factor in Cedarville College life. A brilliant scholar, widely-read in many languages, he is the last resort to which we fall back whenever we want information in any field.

His teaching schedule reflects this mental versatility, for it is always crowded with many hours of classes, in several different fields. German, Latin, Hebrew, Greek, American History - or history of any sort_occasional sciences, advanced Bible courses-all these are included in his average schedule, and he teaches them all equally well, mixing in numerous anecdotes fitting to the given subject, and adding liberal portions of crackers and cheese to the college student's ever-hungry inner man.

Dr. Jurkat holds the purse-strings for the College, and in times like these, that alone qualifies him to be described as a financial genius.

\section{Dean Steele}

In a world of rapidly inceasing complexity, perhaps the most valuable subjects of all as a means of preparation for life are the social sciences. Economics, sociology, and various phases of world history fall within Professor Steele's province, and a survivor of one of his courses is well grounded in a knowledge of the subject.

However, Professor Steele does not confine himself to social sciences; he is also professor of Bible, and of public speech. The debate teams under his tutelage have built up an enviable record in the past two years.

As Dean of Men, and Faculty Advisor for the Y.M. C. A. for several years, he has endeared himself to the hearts of every C. C. man who has come under his regime.

Prof. and Mrs. Steele's home is a welcome gathering place for groups of Cedarville College's students, at parties nad Y. M. C. A. Cabinet meetings, or just for a touch of old-fashioned Hoosier hospitaity.

\section{The Campus}

The trees which beautify the College main campus are of great variety. Shrubbery is artistically arranged around the two buildings, and the long front walk is lined with shrubs and small evergreens.

The Cedar Day platform is the "concentration point" of the campus's beauty, for here a veritable grove of majestic evergreens forms a natural setting for an outside performance.

The baseball diamond to the rear of Old Main is one of the finest of which any college in Ohio can boast; and a practice gridiron is also found on the athletic field.

\section{W. STEELE}

Dean of Men: Professor of Social Sciences and Bible: A. B., Indiana State Normal; Northwestern University.

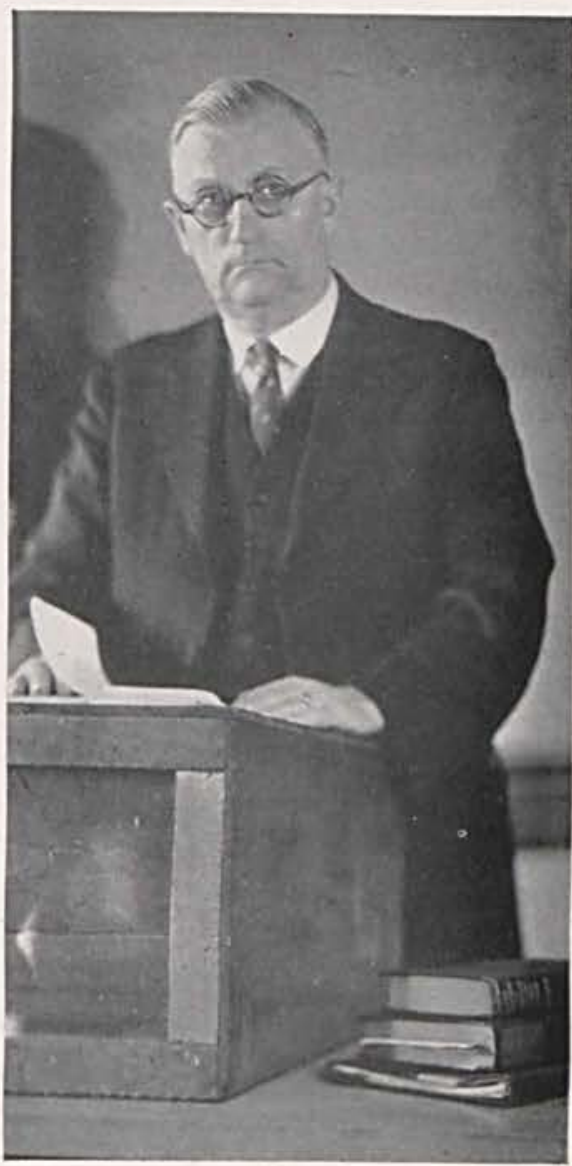


CLASS OFFICERS

Sophomores: Arthur Donaldson, Pres.: Mary Crawford: Paul Rife.
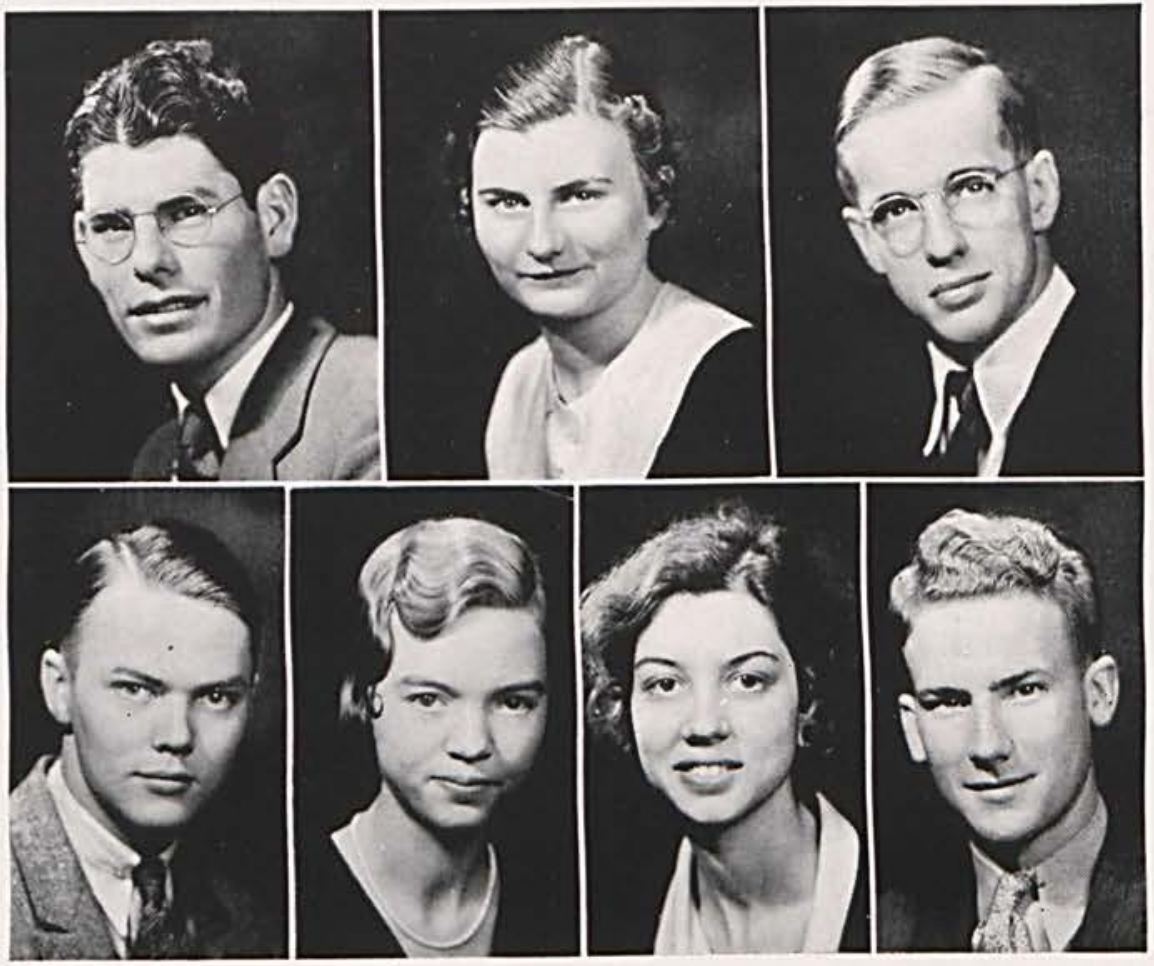

Freshmen: Robert Thompson: Carma Hostetler; Luella Robe; William Reid, Pres.

The college's tennis courts are back of the Alford Memorial Gymnasium; here every year intramural tournaments are played, and the teams from various colleges in the state are met.

Old Main, on the main campus, houses a chapel, the college offices, and a majority of the recitation rooms. Science Hall includes excellent laboratory facilities and science class-rooms in the basement and the first floor, while the Normal Department has its headquarters on the second. Alford Gym has a basketball court, tennis court, showerrooms and locker rooms for men and women students, and other equipment ordinarily found in similar buildings. The Carnegie Library has a capacity of seventeen thousand volumes, and keeps an excellent supply of magazines on file. 


\section{Cedrus Staff of 1933}

Editor-in-Chief

Clyde Hutchison Assistant Editor. Walter Kilpatrick

Business Manager Robert Richards

Assistant Business Manager. Charles Spencer Advertising Manager Charles Bost Music Editor Eleanor Bull Art Editor. Joseph Free

Assistant Art Editor Arthur Donaldson Snapshot Editor.

Snapshot Editor Marjorie Gordon

Diary Editor. Jane West

Athletic Editor. Nina Stevenson

Humor Editor Preston Garlough

Faculty Advisor Homer Murray Prof. Kuehrmann 


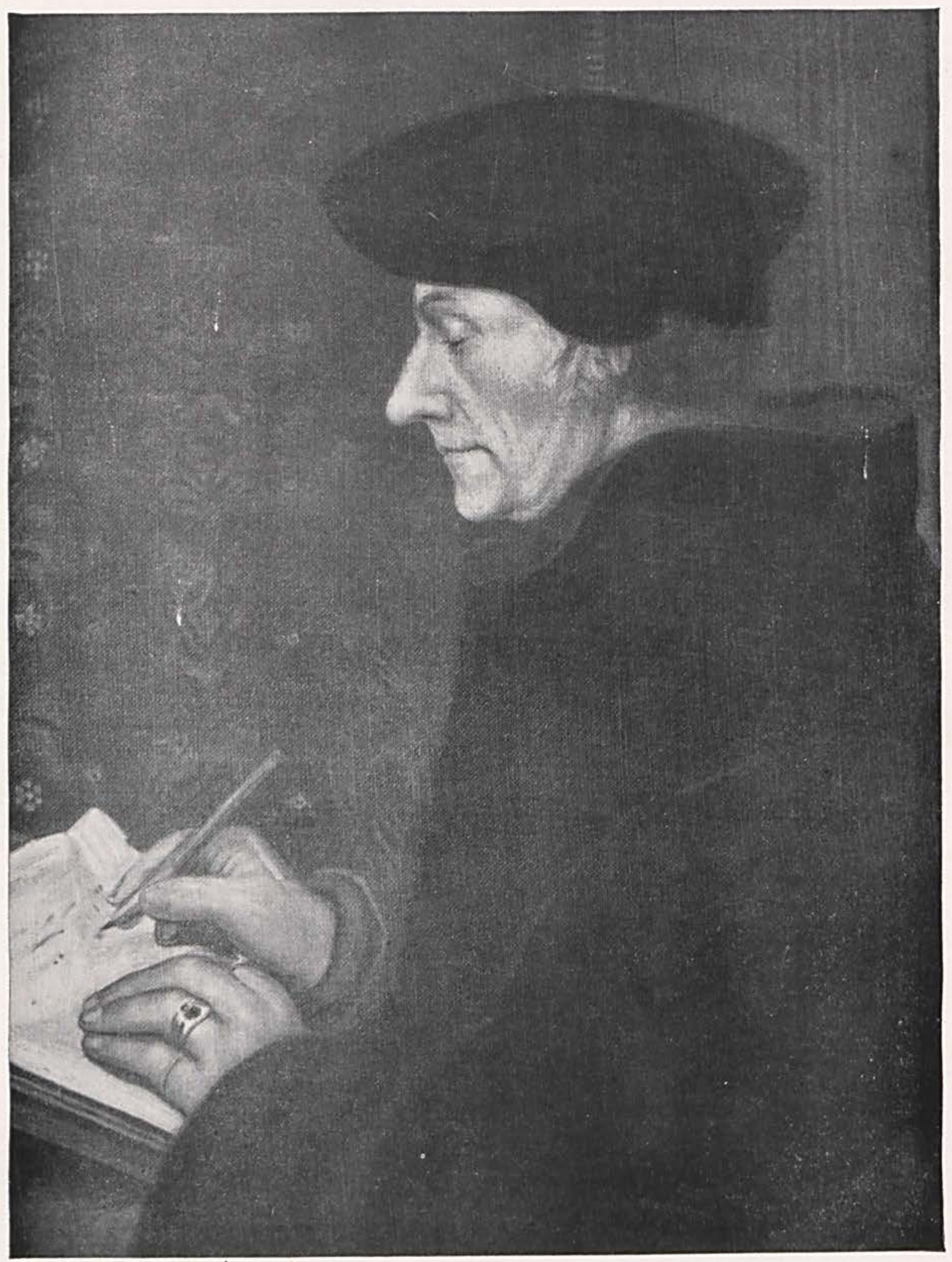




\title{
CHAPTER TWO
}

\section{Literature and Music}

\begin{abstract}
ERASMUS
Desiderius Erasmus, a Dutch scholar of the Renaissance, was one of the promoters of Humanism in Western Europe and England. The great service he rendered was in fighting the battle of sound learning and plain common sense against unenlightenment, and in emphasizing the sovereign place of reason as the ultimate guide in all questions, re ligious and political not excepted.

This portrait of Erasmus is by the famous German master of the early sixteenth century, Hans Hobein.
\end{abstract}

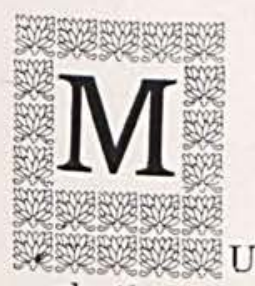

USIC, as we understand it, expresses itself in the inter-action of three elements -rhythm, melody and harmony. The first two are obviously as ancient as human conscousness itself. Without the third, a musical art of permanent value and intelligibility has not been known to attain independent existence. With harmony, music assumes the existence of a kind of space in three dimensions, none of which can subsist without at least implying the others. When we hear an unaccompanied melody we cannot heIp interpreting it in the light of its most probable harmonies. Thus, when it does not imply consistent harmonies it seems to us quaint and strange; because, unless it is very remote from our harmonic conception, it at least implies at any given moment some simple harmony which in the next moment it contradicts.

Music is a mode of motion and is usually thought of as a pleasure-evoking emotion, which has become aesthetic. It is purely human, hence, the cound once set in motion, we are at liberty to dream, to thrill, to weep, to sigh, with all the moods induced by the director.

Music is the youngest of the arts, but it has advanced into popularity far more rapidly than many of the older arts. Much of the musical development of the twelfth and thirteenth centuries was centered in Paris. The troubadours, the jongleurs, and the minnesingers, who cultivated poetry and music, played no small part in the advancement of the art.

Page Fifteen 
We are passing through a modern era of harmonious music. There are two distinct factors contributing to its establishment: first, the Church's need for intelligible chorus and choir music ; and second, the rise of the opera, which contains much solo wcrk, not complete without harmonic accompaniment. Music has advanved through the years from the monotonous chant of the ancient Greeks, through the raspy two-stringed musicbox, the soft tinkle of the harpsichord, the dreamy lull of the harp, to the glowing splendors of our symphonic orchestras, and our wonderful three and four-manual organs, found in our large cities of today.

Imagine, if you will, a week, or even a day, without music of any kind. No chapel songs, nothing but speeches and advertising over the radio, no tunes to hum as you go here and there with your work. You would find it a mighty monotonous world.

Because of this seemingly magic power and charm of music, which manifests itself in the human consciousness, it becomes one of the greatest sustaining forces in mortal existence. Its amelioration of those oppressing influences in our environment, which would otherwise become unendurable, places it high in the scale of aesthetic value, and gives it its indispensible position in the full, wellrounded life. -Eleanor Bull.

\section{Literature}

Literature in its various forms portrays the results of race peculiarities, or of diverse individual temperaments when put into story and verse form. Since man feels before he reasons, poetry generally precedes prose. Hence sacred books and war songs are everywhere the earliest literary monuments, and both are essentially poteic compositions which have received religious sanction. All literature, generally speaking, is imitative. To illustrate this, we know of no earlier beginnings of literary art than in Greece in the days of Plato. From this time on, literature has survived war, pestilence, and even the "dark ages" when it was thought that all in the literary field was doomed, and we have imitated the writings of Greece, Rome, France, Spain, and finally. of the great playwright, William Shakespeare.

Unfortunately for literature, the rhetorical expression of feeling is rarely on a level with its emotional intensity. This accounts for the inferiority of national hymns, which, as a rule, are not of

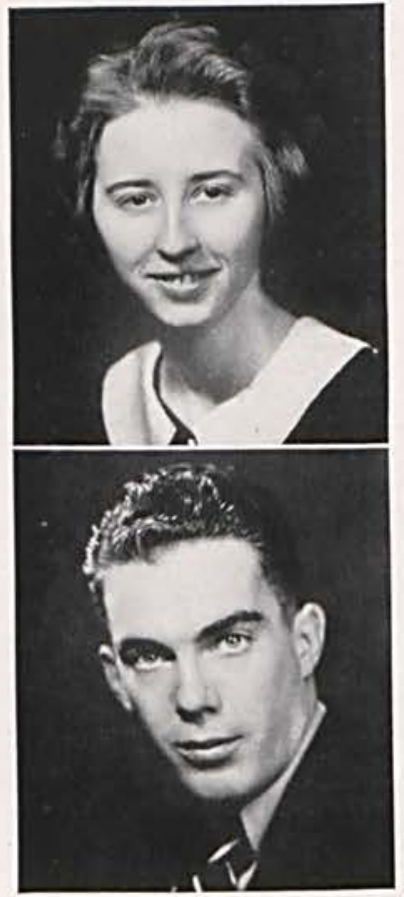

VIOLA HARBAUGH Tippecanoe City, Ohio Student Body Officer 4; Class Officer 3,$4 ;$ Y. W. C. A. President 4: Glee Club 1, 2, 3: Mock Wedding Bride 4 ; Literary 1,2 , 3, 4: Bible Reading Contest, Winner 2: Class Play 4.

WILLIS GORMLEY Cedarville, Ohio Y. M. C. A. ; Literary : Class Play 4 


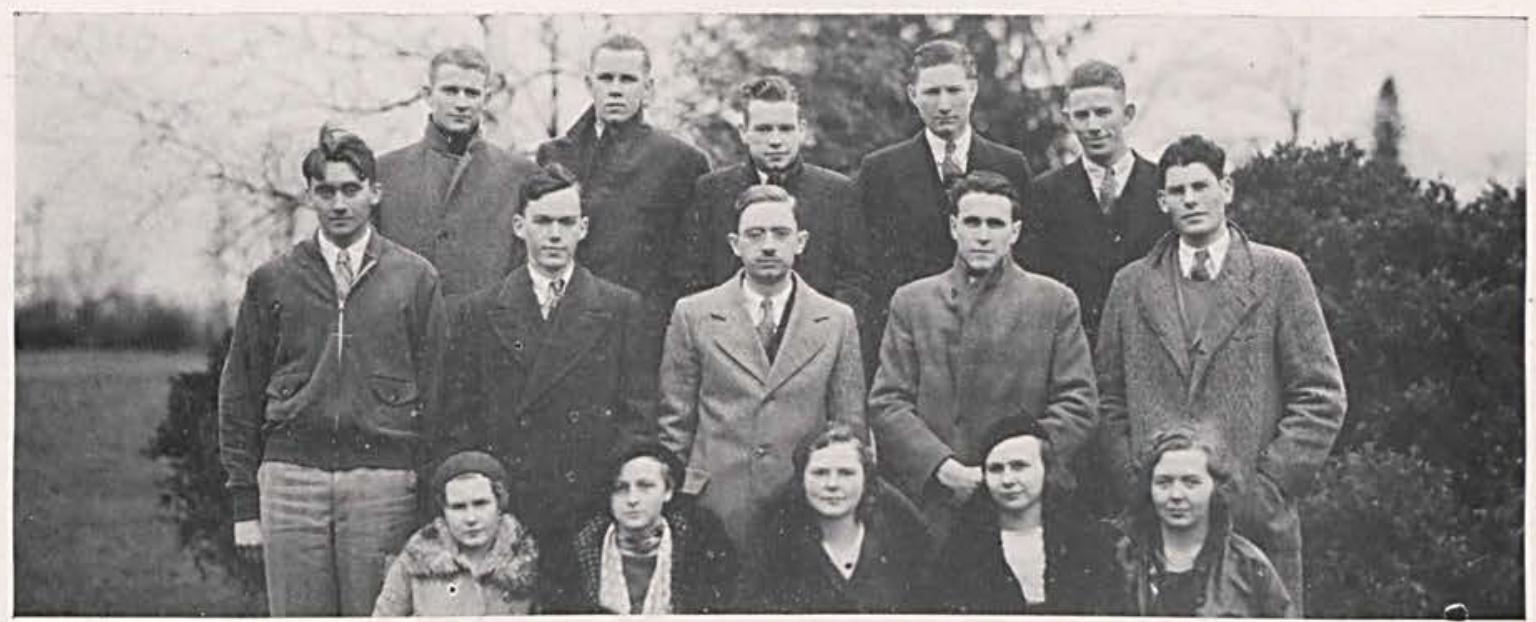

CEDRUS STAFF

First row-Cultice, Gordon, West, Stevenson, Bull : Second row-Spencer, Kilpatrick, Kuehrmann, Free, DonaldThird son:

row-H. Murray, Richards, Hutchison, Bost, Garlough. high order from the point of view of literature. The patriotism of men must needs supply an inspiration which the words themselves lack.

Poetry has received the approval of the generations. Between the distinctly great pieces which all men competent to judge would accept without hesitation, and the distinctly inferior pieces which these same persons would as summarily reject, there lies a vast body of verse, the appeal of which depends on individual choice.

In the colleges of this land we have tried to keep literature at the top of our appreciation list. More and more we are giving our attentions to the so-called developments and movements in literature, which gives us an adequate realization of historical background and perspective. In the universities all over our nation and in foreign lands, we have stressed the requirements of a literary course before graduation. Many of the topics studied by advanced students of literature likewise connect closely with questions of economic and social development.

The rapid growth in circulation of magazines suggests that literature is becoming more and more the chief source of pleasure of the masses. To maintain this position of prominence, literature must contrive to adapt itself to new conditions, and reveal itself in new forms. Through this metamorphosis will evolve an ever higher, more meaningful

FLORENCE MCLAUGHLIN Salem, Illinois Sterling College, Kansas, 1, 2, 3: Mixed Chorus, Glee Clab, Quartett, Mock Wedding Minister, Class Play, 4.

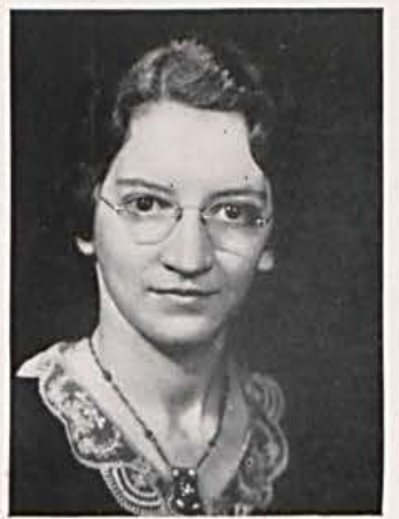

style of literary expression.

-Arthur Donaldson.

\section{Miss Angevine}

In the fall of 1929, all new and former students of Cedarville College had their attentions fixed on the opening of the new year. Special attention was usually attracted to the new additions to the faculty row. Among this body in '29 was Miss Dorothy Angevine, the new head of the English and Latin Departments.

She was the little member of the "big three" who lived at Mrs. Oglesbee's, for the personal chapronage of the Misses Eloise McLaughlin and Sarah Margaret Chance. Miss Angevine amused 
First row : Robert Ross, Paul MeLaughlin, Lois Cultice, Homer Murray.

Second row: Margaret Berk, Glenna Basore, Walter Kilpatrick, Nina Stevenson.

Third row: Raymond Hargrave, Lloyal Ross, Doris Hartman, Ralph Moorman.

Fourth row: Robert Bratton, John Mills, Regena Smith, Edward Tedrick, John Murray.

herself daily with Miss Parry's attempts to keep the females of the institution in the straight and narrow path. Little did she realize that by the time another September had rolled around she would have been advanced to the coveted position of Dean of Women at Cedarville College.

She has continued as most efficient Dean of Women for the past four years, although that is not the only new job she has taken onin fact, she has something new every year. she now teaches French, Spanish, English, and Latin, and seemingly thrives on variety for she renders her services efficiently and cheerful-

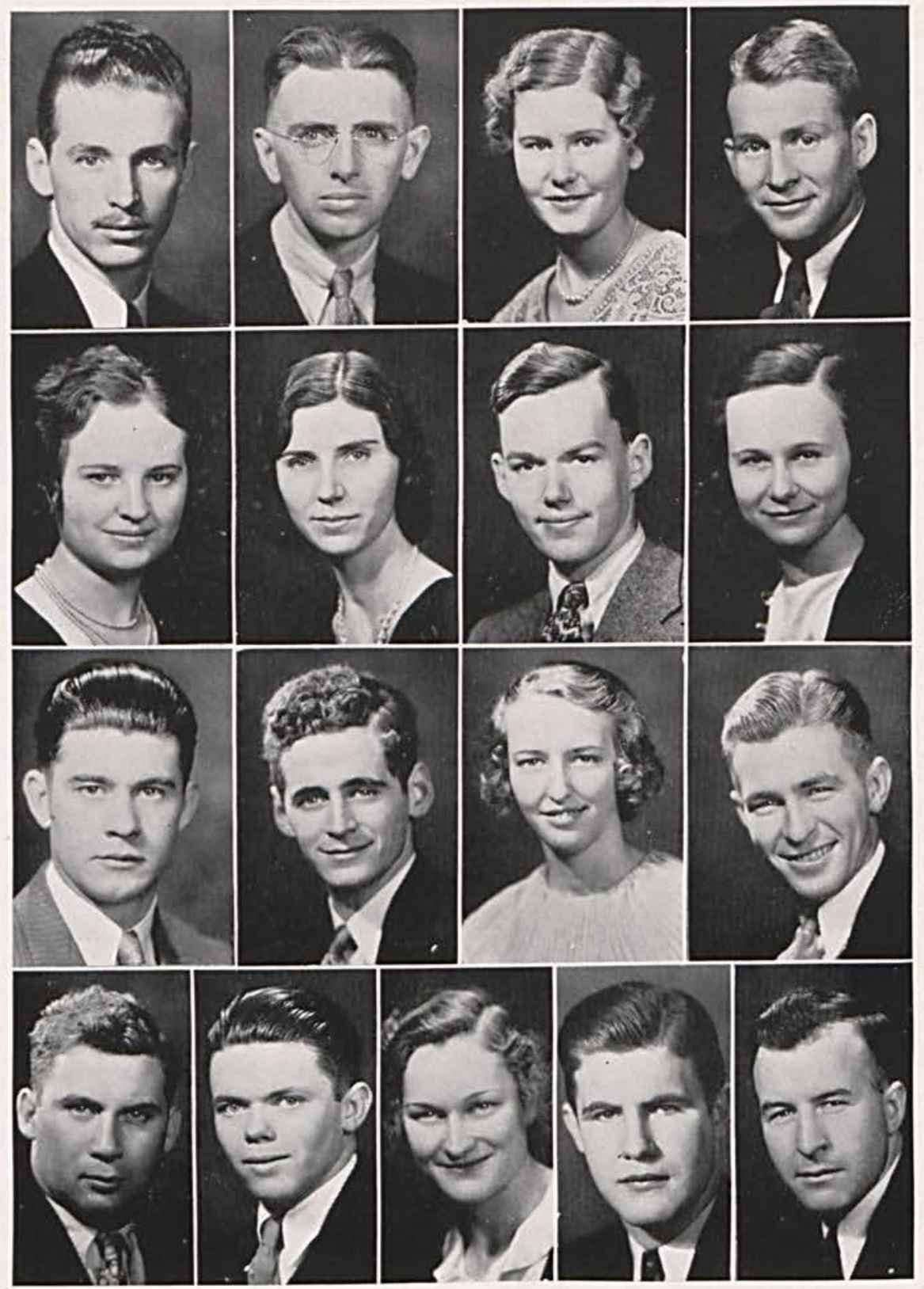
ly. We know of no one who is more willing to help the person who really wants help. Anyone who wins her friendship feels proud of the fact.

\section{Mrs. Work}

Mrs. Margaret J. Work, our diligent and efficient Director of Music, has had excellent training and experience for the position. After graduating from high school with first honors in a class of ninety-three pupils at Washington, Pa., she attended Mommouth College, where, in her junior year, she received a music diploma, and later graduated with two degrees-Bachelor of Arts and Bachelor of Music. There she was elected to "Sigma Omicron Mu," a national honorary sorority. 


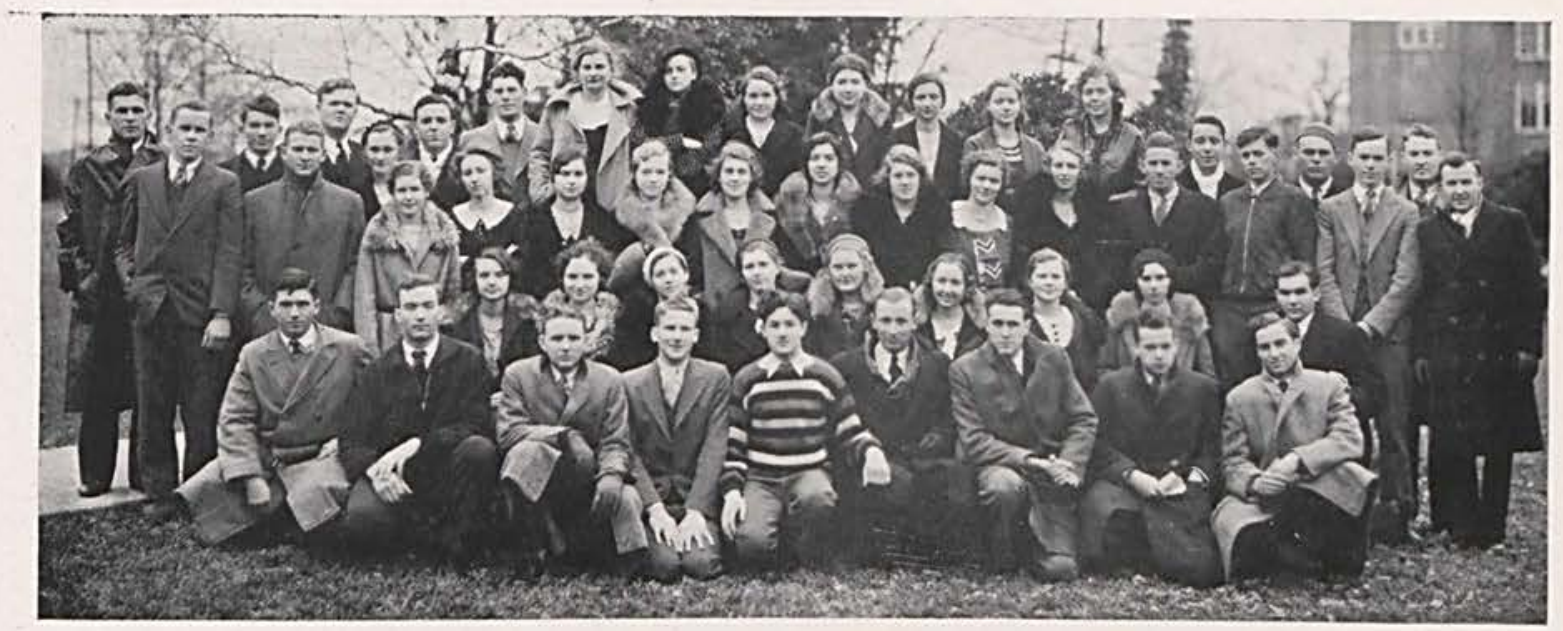

LITERARY SOCIETY

First Row: J. Finney, Ferguson, Linton, W. Reid, Cap pola, Brigner, Free, Hutchison, Kitchen: Second Row: Pyles, Berk, Bradley, Patterson, Atchison, Probasco, West, Basore, R. Murray; Third row: Richards, H. Murray, Cultice, Harbaugh, Labig, Hostetler, Chenoweth, Robe, Watson, Turnbull, Hartman, Garlough, Chirstian, Kilpatrick, J. Murray ; Fourth row: Moorman, Nelson, Trubee, MeNamee, Donaldson, Crawford, Gor don, Auld, O. Brill, C. Brill, M. MeLaughlin, Bull, Harriman, MeHenry, MeCallister.

Immediately following her graduation, she taught at Arcanum, Ohio, for three years, until her marriage to Albert S. Work. They resided in Frenchburg, Kentucky, where she taught for three years.

After the death of her husband, she accepted her position here. In the summer of 1932, she attended the Lamont Conservatory of Music, at Denver, Colorado, where she is working on her Master's Degree in Music. of Music.

Mrs. Work teaches French and rhetoric in addition to her directing of the Department

\section{Miss Basore}

Miss Basore, instructor in Oratory, came to Cedarville from Ohio Northern, where she took special work in the public speech department. She conducts her Oratory class in a most interesting way, and it has proved very popular.

Besides instructing in the Department of speech and pursuing her regular student. work, Miss Basore directs the various college plays.

\section{Mixed Chorus}

This newly-organized club-the Mixed Chorus, a well balanced four-part grouping of thirty-six voices-has done excellent work.

At the beginning of the year, the following officers were chosen: President,

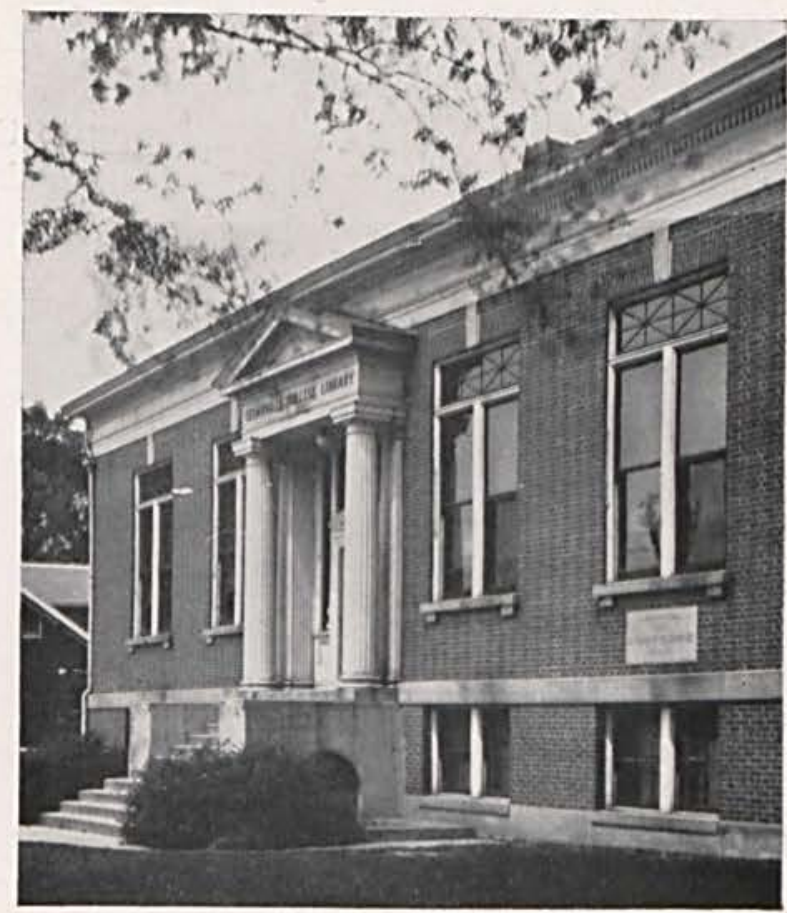

CARNEGIE LIBRARY 
Preston Garlough; vice president, Eleanor Bull; and secretary, Ruth West.

A large share of the honor for the club's achievements is given to the worthy director, Mrs. Work. Her splendid leadership, together with equally splendid cooperation of the members, soon started the chorus on the road to success.

At the Home-Coming Banquet in February, the chorus presented two groups of secular numbers; April 15, the group broadcasted an Easter cantata over W:AIU in Columbus,, and presented the same contata, entitled "The Lord of Life," Easter evening in the local Methodist Church at the Union Service.

Miss Dorotha Corry has been the accompanist for the year.

\section{The Girls' Glee Club}

The Girls' Glee Club, composed of twenty-two members and its capable accompanist, Miss Dorotha Corry, has been doing splendid work this year under the supervision of its new director, Mrs. Work.

The officers of the club are president, Jane West; vicepresident, Doris Hartman; secretary, Carma Hostetler; and librarian, Florence McLaughlin.

The club has made numerous public appearances. It sang at the Boys' Bible Reading Contest, the Day of Prayer for Colleges, Wilberforce University, the second United Presbyterian Church in Xenia, the Parent-Teachers Association at Ross, the United Presbyterian Church in Jamestown, and the Glee Club Concert.

If the public has enjoyed listening to these programs as much as the club enjoyed giving them, the year's work has truly been a success.

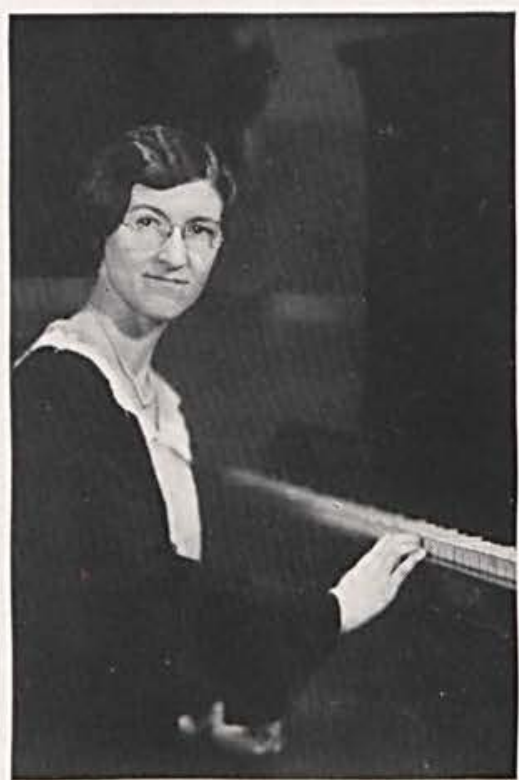

MARGARET J. WORK

Professor of Music, French and English; A. B., Monmouth College: B. M., Monmouth College; M. M., Monmouth College Conservatory of Music ; Lamont Conservatory
of Music, Denver, Colorado.

MIXED CHORUS

First row-V. Garlough, Brigner, Richards, Hutchison, Rife; Second row-Patterson, Atchison, Crawford, M. Gordon, Probasco, Bennett; Third row-Chamberlain, Harriman, Ferryman, Corry, Mount, Robe, Watson, Turnbull, Wham, Hartman, Free, P. Garlough, Christian; Fourth row-Mrs. MeLaughlin, M. Laughlin, Bull.

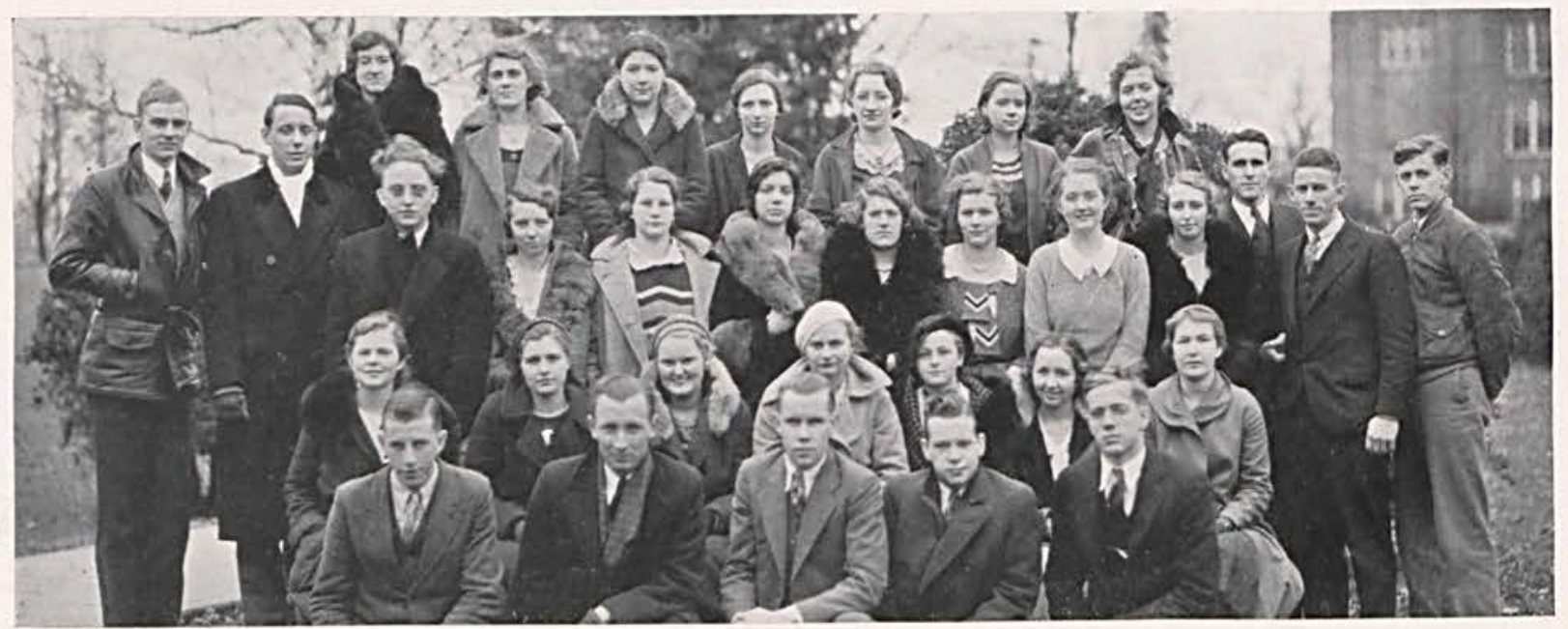



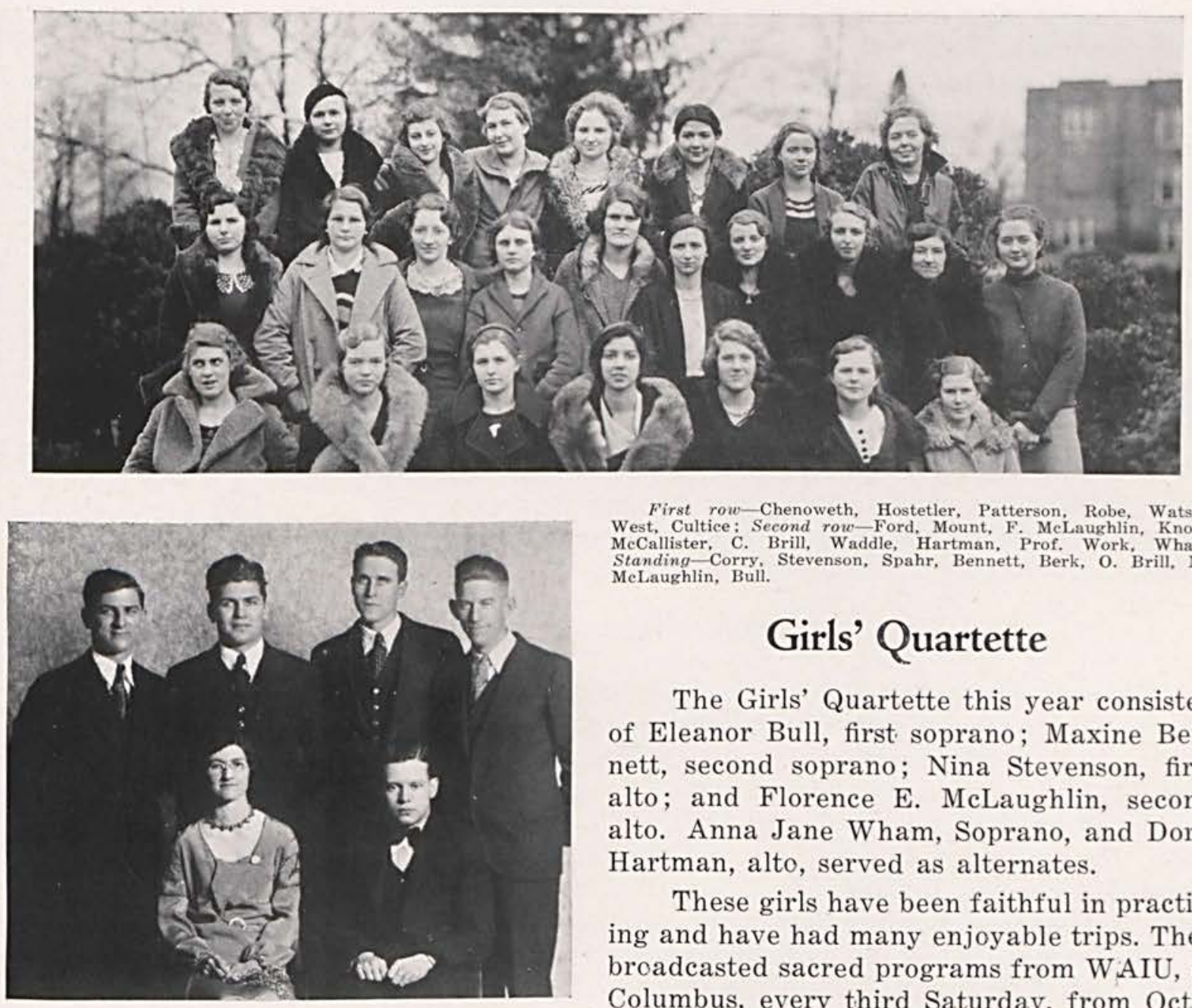

MALE QUARTETTE

Seated-Prof. Work, Clyde Hutchison: Standing-George Gordon, Edward Irons, Joseph Free, Preston Garlough.

heavy snows, and dense fog on those dark driving.

The girls sang in Xenia at the O.S. and S. O. Home, the Kiwanis Club, and some of the Xenia Churches. They sang in Clifton, West Jefferson, Ross, and for various church, school and club programs in Cedarville.

The quartette enjoyed singing together and accredit much of their success to their tireless and patient training by Mrs. Work.

\section{Male Quartette}

The personnel of the quartette this year was the same as last year. Their experience in singing together contributed to the harmonious blending of their voices and to their subsequent popularity.

Their interest in music was rivalled by their sh $3 r$ in other extra-curricular activities. Nevertheless, they were all faithful in attending rehearsals, and the records show a busy

Page Twenty-one 
season, which included appearances at various campus programs, at local church services, before clubs in Xenia and Dayton, and a broadcasting program.

Two of the members chose the Christmas vacation to have hospital experiences, but the beginning of the second semester found everyone ready for work again. Those studying in the library on Tuesday and Thursday evenings have learned to concentrate through the harmony of "The Blind Plowman" or "Prayer Perfect," and they know it is time for the library to be closed when they hear the boys signing off (informally) with "Moon, Moon, Pretty Silvery Mocn."

The members of the quartette, directed by Mrs. Work, are George Gordon, first tenor; Edward Irons, second tenor; Joseph Free, baritone; Preston Garlough, bass; Clyde Hutchison, alternate an accompanist.

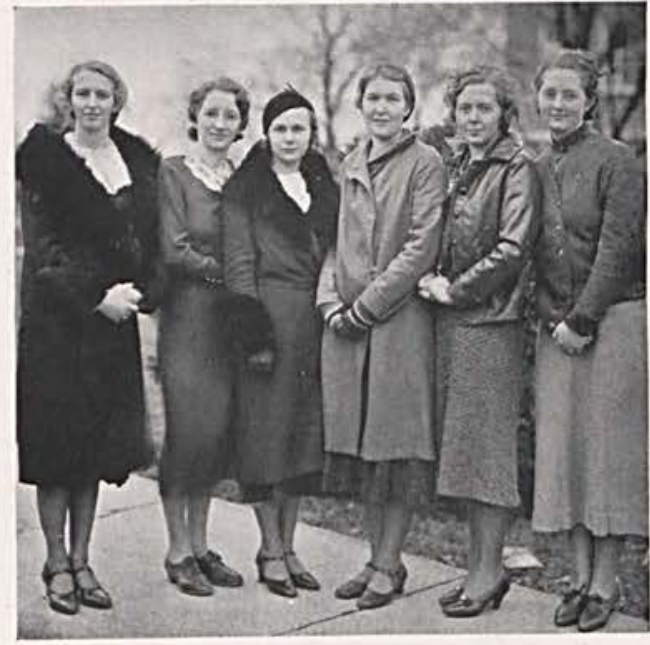

GIRLS' QUARTETTE .

Hartman, F. MeLaughlin, Stevenson, Bennett, Bull, Wham.

\section{Inter-Collegiate Debates}

History repeats itself this year in intercollegiate debating at Cedarville College. The standards set last year have been more than equalled. The number of non-decision debates is less, the decision debates greater. Our team, upholding the affirmative, has engaged in five contests on the question, "Resolved that all banking functions should be regulated by the Federal Government, with deposits guaranteed," and has won four of them. Four of these debates occurred at the Manchester College Debate Tourney held at North Manchester, Indiana. C. C. registered wins over teams representing Wheaton College (Illinois), Huntington College (Indiana), and Manchester College, but lost to Illinois Normal College by a slight margin. The fifth debate of the season and the only home contest was with Wilmington College. Prof. P. B. Brees of Wittenberg College was the judge and gave C. C. the decision by a few points.

The sixth and final meet of the year will be at Rio Grande College, Thursday, May 25. C. C. Won there last year, and the boys are determined to repeat the victory.

Data regarding future prospects include the following: two members of the team will be lost by graduation, Joseph M. Free and Clyde A. Hutchison, Jr. Their places will be hard to fill. Parenthically, to Joe Free goes more credit than to any one else for the resumption of intercollegiate debating, and both of the boys will be missed because both love to debte and are willing to make real preparation, the latter a virtue not always outstanding. The two remaining members are Walter S. Kilpatrick and Franklin Trubee, both Juniors. These boys love forensic contests and have the spirit that says, "The team first."

From these facts, the statement is warranted that the prospects for a strong squad next year are good. Further, the response to the call recently issued for recruits, indicates that C. C. will have several teams next season.

\section{Philosophic Literary Society}

The Philosophic Literary Society of the College has achieved prominence this year through increased membership, and well-planned meetings. 


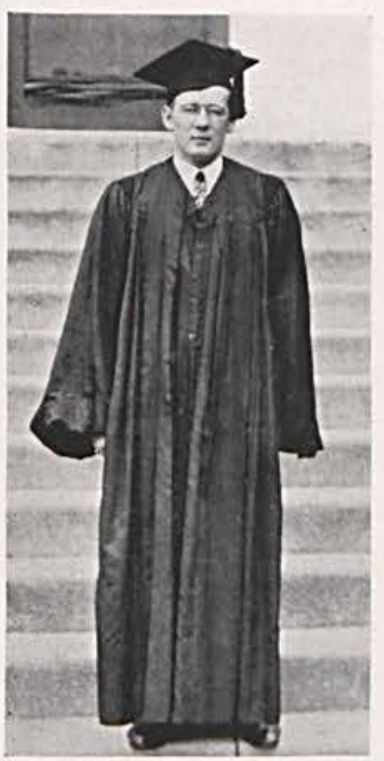

DR. EdWARD P. EIGENSCHENCK

Forty-three members were enrolled and the meetings were unusually well attended. Not only the enrolled members, but many guests enjoyed the instructive programs, including a mock trial, readings, music, debates, and playlets.

Among the guest entertainers during the year were Ruth Marshall, pianist, and Raymond Chenoweth, accordionist, each of whom furnished an evening's entertainment. Also members of Prof. Steele's class in argumentation debated the question, "Resolved, that the Federal Government should grant old age pensions."

The society affords the students the opportunity of developing their literary, elocutional, and musical talents.

Officers are elected each semester. For the first term, Joseph Free was elected president; John Murray, vice-president; Beatrice Pyles, secretary; Carl Furgeson, treasurer; Walter Kilpatrick, chaplain; and Art Donaldson, sergeant-at-arms.

Homer Murray was chosen president for the second half-year, with Jane West, vice-president; Lois Cultice, secretary; Art Donaldson, treasurer; Walter Linton, chaplain; and Franklin Trubee, sergeant-at-arms. 


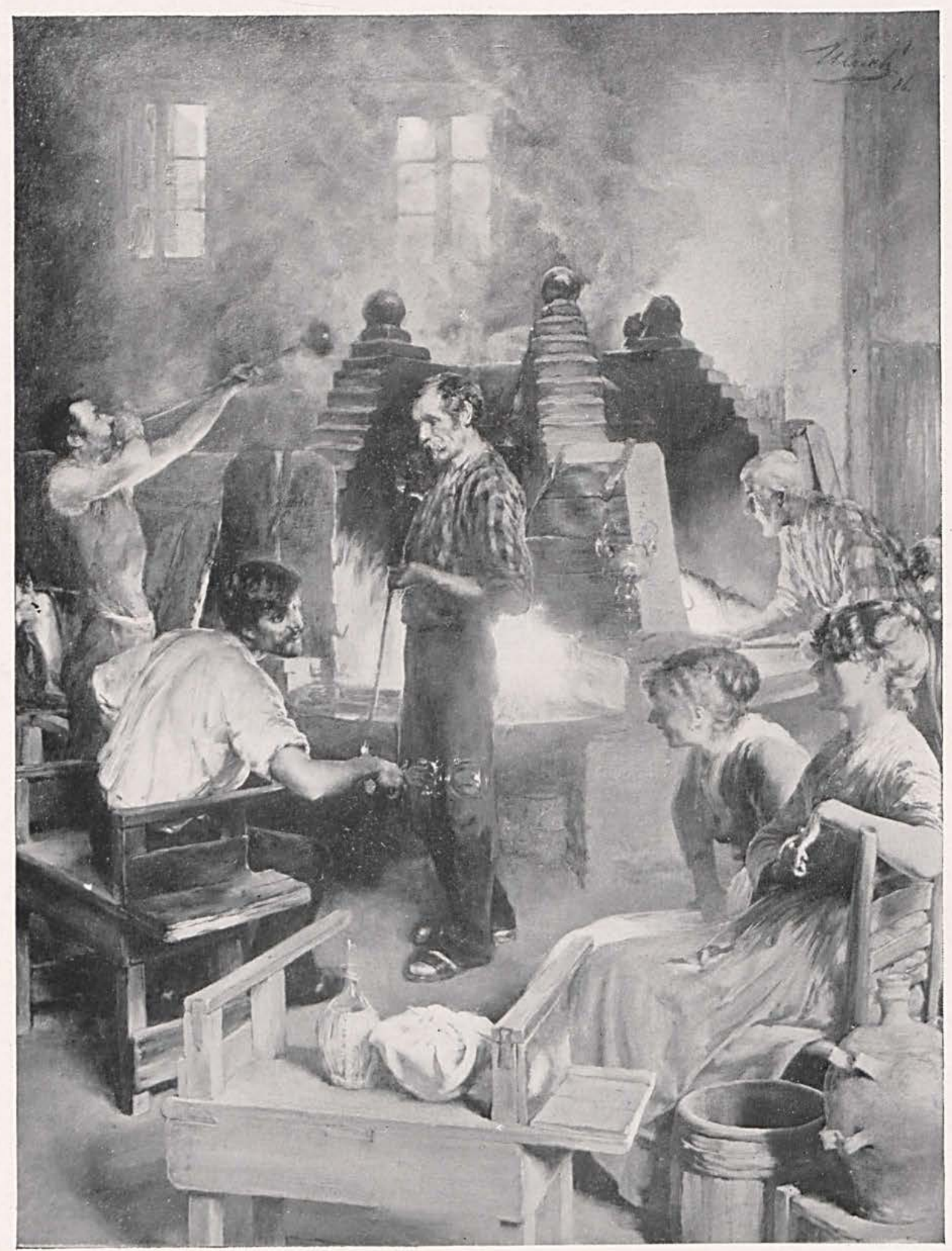




\section{CHAPTER THREE}

\section{Science}

\section{GLASS-BLOWERS OF MURANO}

The American painter, Charles Fredrick Ulrich, who delights in painting people working at their profession, has in this picture given us a glimpse of Glass-blowers in the Italian city, Murano, plying their trade which has been an art since many centuries before the dawn of Christianity.

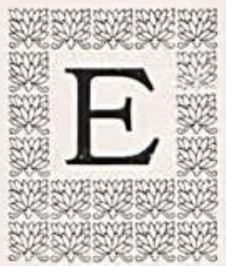

VERY branch of knowledge had at some time a beginning. So science at some time in ages past had a beginning-probably a very meager one, and one which was not added to very rapidly or with any great degree of certainty. This branch of knowledge has met with many misfortunes and with much bitter opposition but it has prospered and grown because of the fact that it has a solid foundation of truth, and because it has rendered a service to the world which fully justifies its existence.

Probably, if we should go back to the very beginning of science, we woud find it nearly contemporary with the first appearance of man. Even in his simple primitive life he observed scientific facts, though he could not recognize them as such. He saw the daily rising of the sun in the east and its setting in the west. He saw the flowing and the ebbing of the tide each lunar day, the passing of the seasons and their recurrence each year.

Each Spring he saw the melting of the snows with the coming of warm weather. Then came the budding of the trees and the springing forth of the grass, the sprouting of seeds and the growth of many flowers and plants; in the animal kingdom there was increased life and activity.

Man learned to look forward to the coming of Spring each year, and he had faith, because of past experiences, to believe that it would come.

By this time he had discovered that the laws of nature are uniform and that their existence was permanent. It was expected that winter would again follow the warm days 


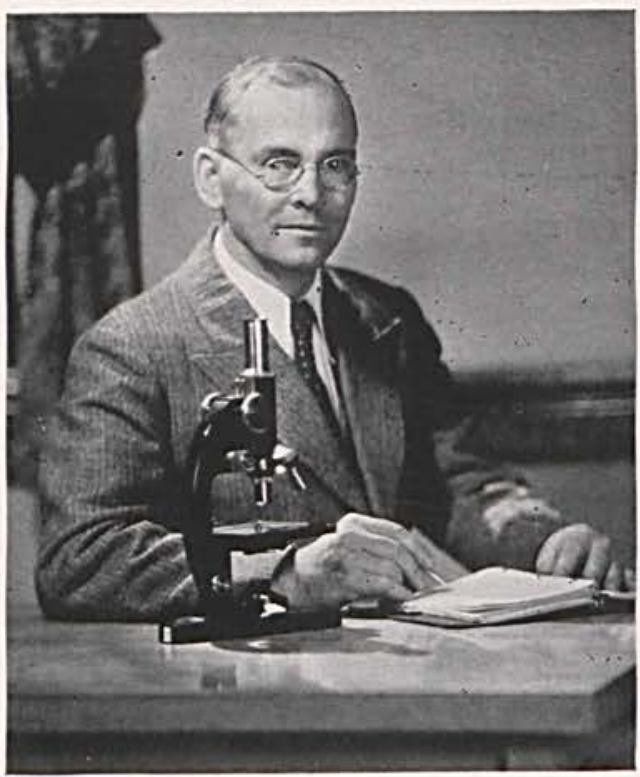

A. J. HOSTETLER

Registrar: Director of Teachers' Training; B. S., Ohio Northern University; A. M. Wittenberg College.

of summer. He knew that there would then be a scarcity of food and a need for shelter and clothing. Another step forward in his development was taken when he used his scientific knowledge to provide for the coming season.

Then in spite of all this knowledge of facts and laws came an error in man's thinking. He failed to realize that all the things which happened about him were the result of some cause, and that there was a scientific reason for it. Even though he had seen the uniformity of these laws and had even applied some of them for his own use, when he began to search for the reason and causes for things, he substituted fantasy and superstition for the true causes. $\mathrm{He}$ would rather have a number of mythical gods and live in a world ruled by their whims and fancies than to accept the well planned and orderly world in which he actually lived.

These superstititions and opinions were so popular that when someone did use sound reasoning and arrive at true conclusions he was not believed; in fact, he was in danger of being persecuted for his heresy. The early scientists were said to be practitioners of "Black Arts" when, in truth, they were the most enlightened individuals in the world. So we find that science met with such bitter opposition and had such a struggle for existence that its growth was very slow, especially in these early years. The old superstitions, however, were so popular and so firmly fixed that they persist even to this day - a day which is said to be the scientific age.

Truly this seems to be the beginning of a great scientific era. People are becoming science-minded. We have in our grasp a great fund of knowledge and an aptitude for its application. Our duty is to apply it in the right way. It can easily be seen that with improper motives and objectives this whole civilization of ours could be wiped from the

SOPHOMO RE CLASS

First row: Trubee, Ferryman, Ferguson, MeNamee; Second row: Pyles, Mount, Patterson, Watkins, Lunsford, Atchison, M. . Wrill, West, Probasco, Crawford, Walker Fourth row : Kitchen, Finney, Rife, Christian, Tindall, E. Spencer, Kenfield, Cash, Nelson, Donaldson, MeCallister.

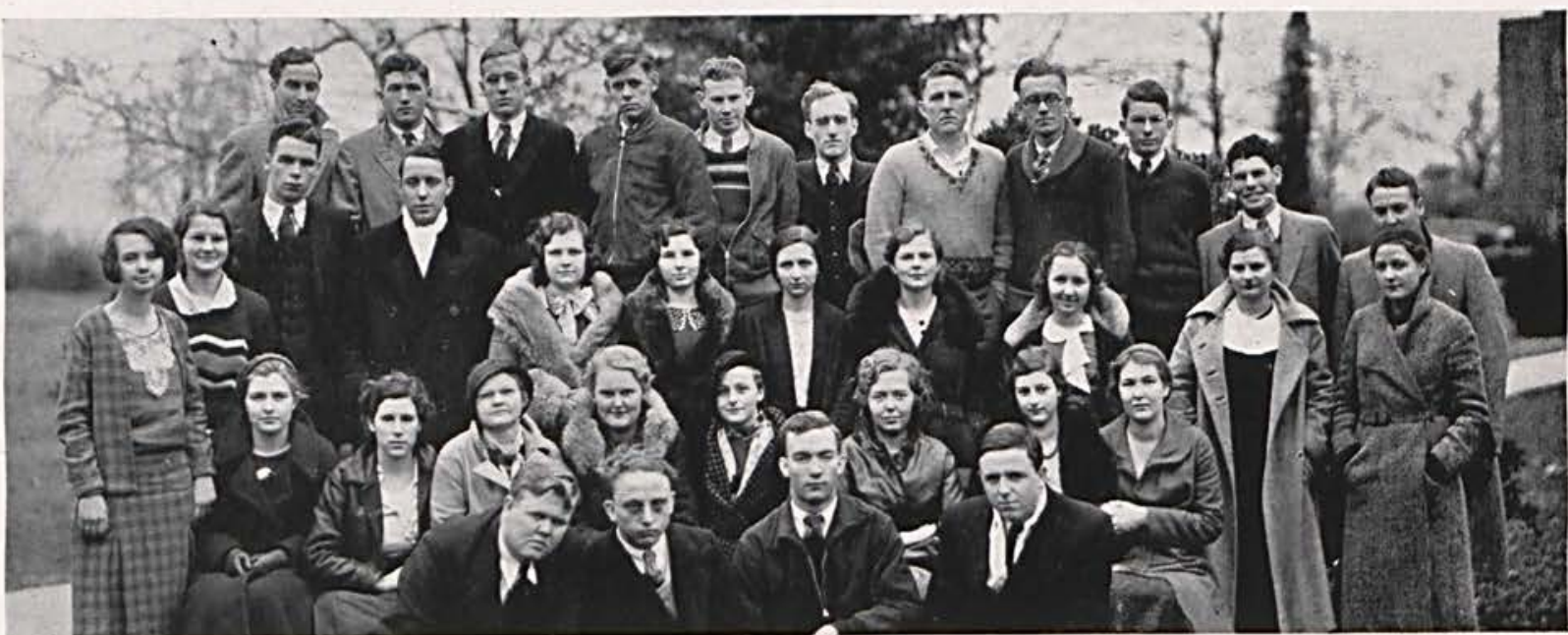




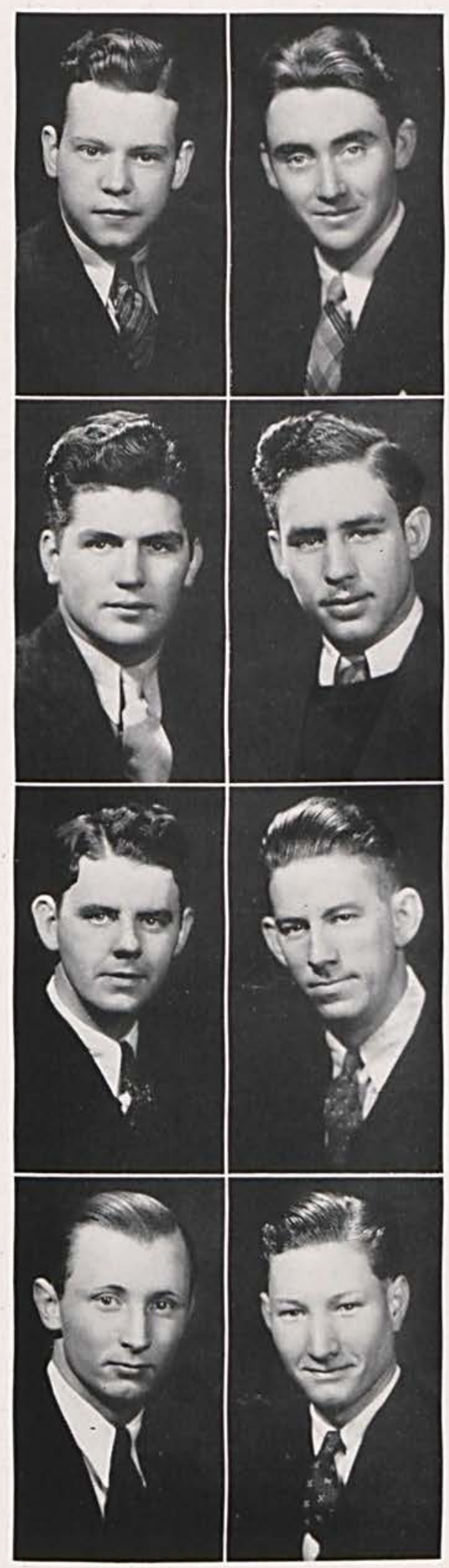

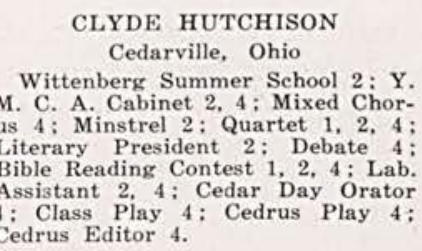

EDWARD IRONS

Post Graduate.

$$
\begin{aligned}
& \text { LEO REED } \\
& \text { Clifton, Ohio } \\
& \text { Post Graduate. }
\end{aligned}
$$

\section{CHARLES BOST}

Springfield, Ohio

Student Body Officer 4: Class of ficer $3 ;$ Y. M. C. A. Cabinet 4 Crown Club 3: Minstrel 3: Basketball $1,2,3,4$ : Baseball 3,4 ; Lab. Assistant 3 . Class Play 4: Cedrus Play 4: Cedrus Staff 3,4 .
Wellston, Ohio

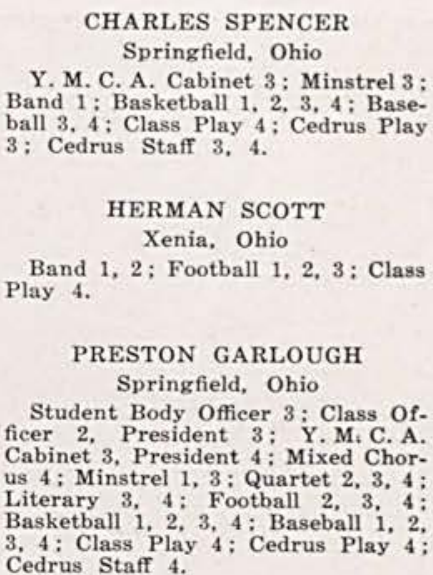

CHARLES SPENCER

Springfield, Ohio

Y. M. C. A. Cabinet 3; Minstrel 3; Band 1: Basketball 1, 2, 3, 4: Baseball 4 , Class Play 4 , Cedrus Play

PRESTON GARLOUGH Springfield, Ohio

Student Body Officer 3 ; Class Officer 2, President 3; Y. M: C. A. Cabinet 3 , President 4 : Mixed Chorus 4: Minstrel 1, 3: Quartet 2, 3, 4 Basketball 1, 2, 3, 4 : Baseball 3, 4: Class Play 4: Cedrus Play 4 : Cedrus Staff 4.

$$
\begin{aligned}
& \text { EDGAR BRIGNER } \\
& \text { Cedarville, Ohio } \\
& \text { Y. M. C. A. Cabinet } 3: \text { Mixed } \\
& \text { Chorus } 4 ; \text { Minstrel } 1,3 ; \text { Band } 1,2 \text { : } \\
& \text { Literary } 1,2,3,4 ; \text { Class Play } 4 .
\end{aligned}
$$

earth by the very thing which can make it a more worth while place in which to live.

At present, science is being usefully and profitably applied in many fields. It is serving as a basis for practically every industry and profession. It is found to be in complete harmony with all things including not only industry, business, agriculture, and the professions, but also religion. Probably one of the most important applications is in education where scientific methods of teaching are procuring results far beyond the inefficient methods of past years.

A great contribution of science is the establishment of the scientific method of thinking which bases all decisions on experimental evidence and observed facts, and gives no place to superstition, opinions, and prejudice. With scientific thinking there is a desire for truth in all matters.

The fact that this is a scientific age well under way, makes necessary the education of every individual to appreciate science and to have a general understanding of natural phenomena, as well as the highly specialized training of individuals for each branch of science.

-Charles Spencer.

In Cedarville College, science and mathematics are taught in such a way as to make for their appreciation. For those who intend to specialize in these subjects there is also the opportunity to get the detailed knowledge that is necessary for specialization.

For the future we predict that a greater interest will be shown in the science department of Cedarville 


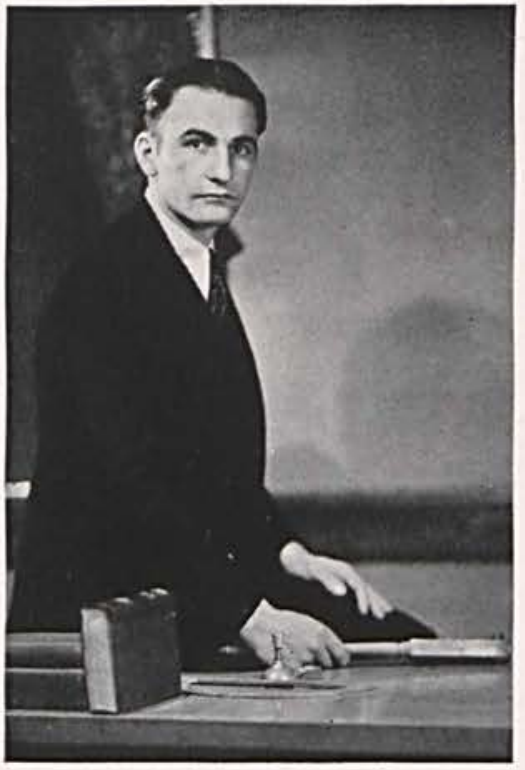

JOHN W. AULT

Director of Physical Education: Profesysies: B. S. State College.

College, for the experience and personality of the professors and their ideal of practical science will appeal to increasing numbers of students.

\section{Mr. Kuehrmann}

Mr. Kuehrmann, who is professor of our chemistry department, is liberal in his views concerning science. $\mathrm{He}$ makes the following statements about his own aims for teaching chemistry:

"The ideal before us in the teaching of college science is to adapt the instruction to the best interests of the student. The general aim may be said to include an effort to make men and women intellectually responsive in ways that are characteristically scientific. We wish to train intellects and to develop in the individual an abiding desire for the truth in all matters. Our science work is emphasized with due regard for the other aspects of student life which together make for a well balanced individual experience."

\section{Mr. Hostetler}

Again in the biology department we find subjects being taught in a practical way. Professor Hostetler says that the tendency in science today is to get away from the philosophical side, and to get at things first hand. His instructions exemplify this new methotd, for the biology lab contains many specimens of the things being studied. Many trips are made into the field, so that students not only collect specimens with which they will work, but also observe them in their natural environment. Biology comes close to one's everyday life and it holds many possibilities for enriching life and making it more thoroughly understood. Professor Hostetler thinks that although the practical work is most useful, yet some place should be given to theory.

\section{Mr. Ault}

Our professor of mathematics is J. W. Ault. In keeping with modern mathematics methods, Professor Ault teaches the things which can be used in different branches of science and that can be applied in a practical way in everyday life. He departs for the old method of memorizing facts and stresses instead a logical method of thinking. $\mathrm{He}$ believes that in mathematics the main thing to learn is to organize material, and then

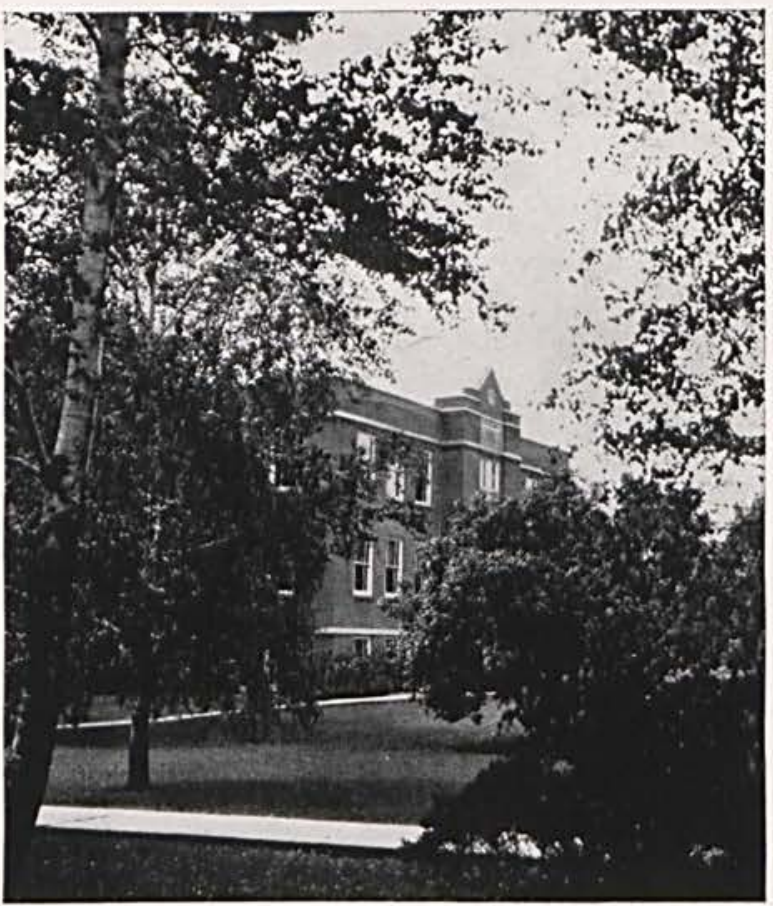

SCIENCE BUILDING 
O. W. KUEHRMANN

Professor of Science: B. S., Purdue University: Butler University: Ohio State University.

to apply it to the solution of the problem. Mathematics taught in this way can be used in many and varied situations.

Professor Ault's collegiate training was received at Bowling Green State College, where he prepared especially for the teaching of mathematical services. $\mathrm{He}$ was also very active in athletics, and as director of physical education at Cedarville, he is enabled to maintain this interest in sports.

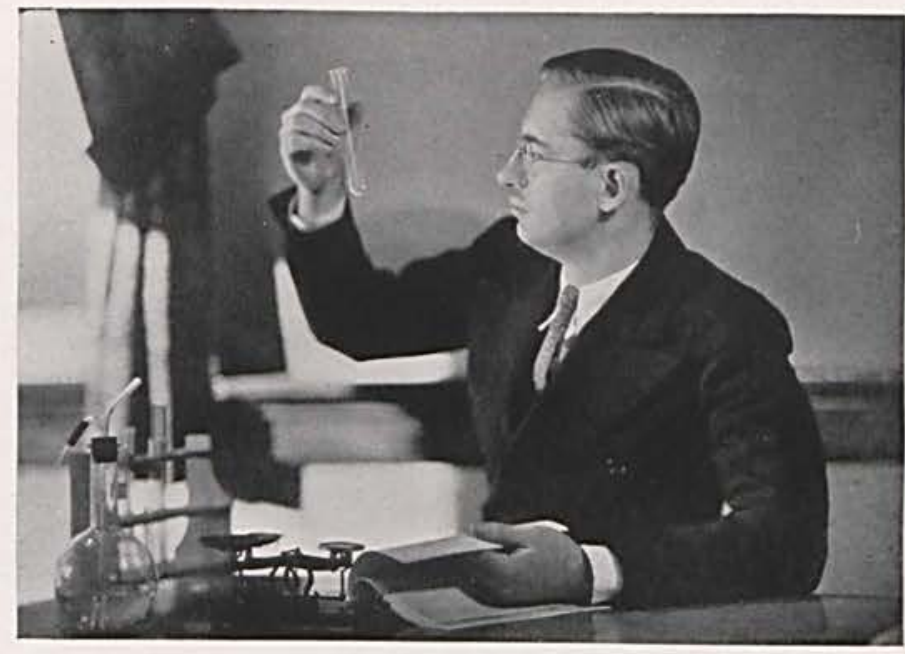




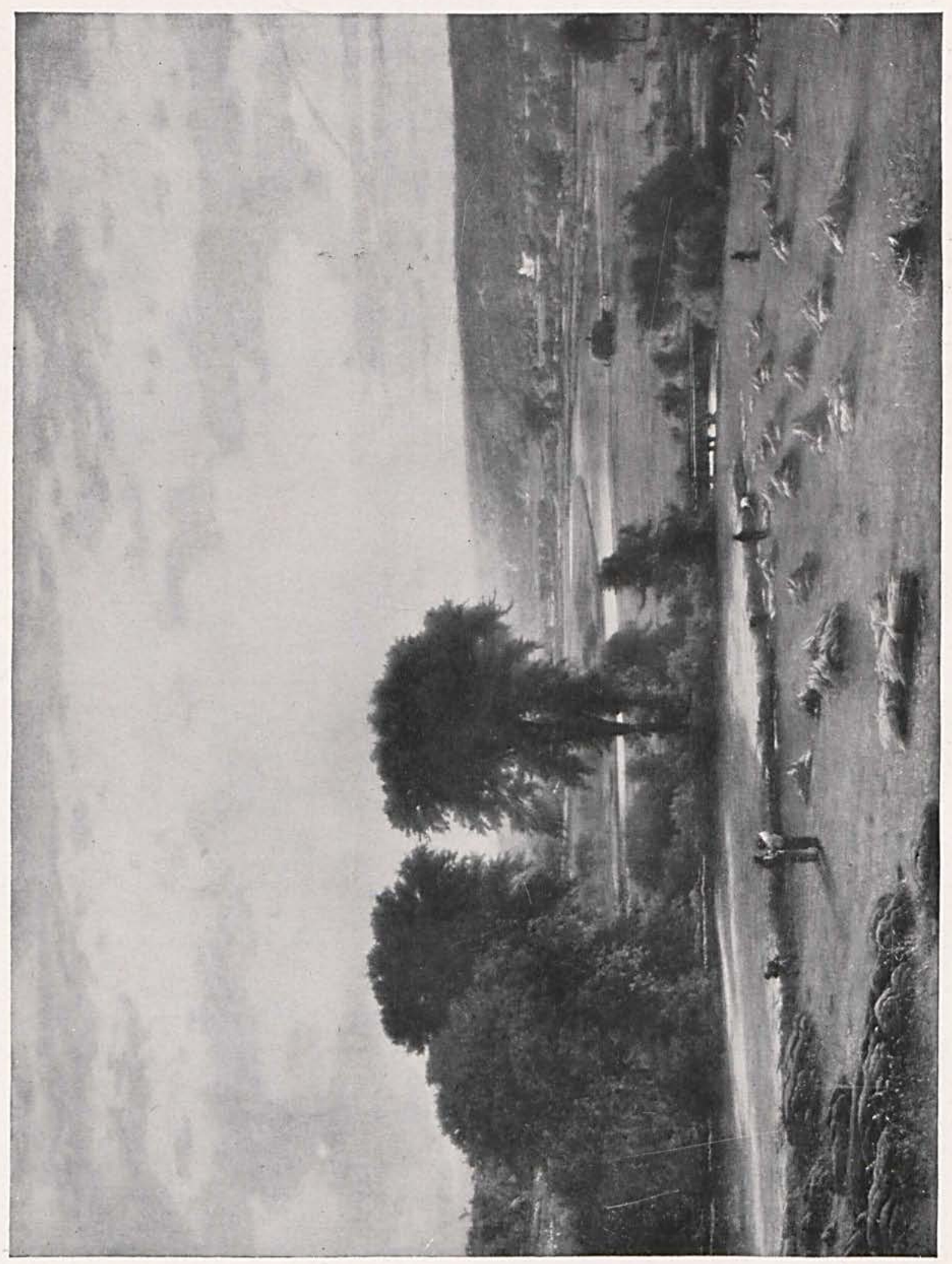




\title{
CHAPTER FOUR
}

\section{Vocations}

\author{
"PEACE AND PLENTY" \\ "Peace and Plenty," an autumnal scene by the American land- \\ scape painter, George Inness, shows the harvest, the reward gained by \\ hard toil. \\ Inness is considered the most prominent figure in early American \\ landscape, by the excellence and scope of his art and the versatility of \\ his treatment.
}

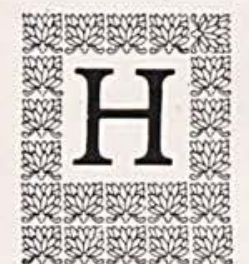

OW we search in vain for the unconventional in writing on a subject of this sort! And how uniformly unsuccessful we are in attaining it. This whole matter of vocations is so far-reaching in its implications that to deal with it in a few hundred words convinces us at the outset that we are doomed to utter failure.

Vocation in the common use of the term, means job. To the educator it may mean a chosen job, a tailored position for an individual of definite measurements, or a tailored individual for a position of definite measurements.

Yet our thinking during these past few years is so influenced by general employment conditions that we begin to wonder if "choice of vocation," "vocational guidance," "what shall I be," and similar phrases have any real meaning at all. But upon deeper reflection, we conclude that, whether the supply of workers be too great or too small, the problem of putting the right man in the right place stays with us.

We endeavor to solve this problem at college, but we must admit that our success is rather indifferent. Probably it is chance, in one form or another, not aptitude or merit, which determines what shall constitute our vocational niche in society. Our older brother becomes a school teacher. He makes a living, enjoys the association of interesting people and a few of life's luxuries; we conclude that we shall be school teachers. If deep down within our hearts we have a persistent suspicion that we would be a better doctor than teacher, and if we secretly decide that teaching shall be our stepping-stone in that direction, then we must do one of two things: bear the brunt of being a "transient" if we make our secret known; or consider ourselves hypo critical toward the teaching profession if we keep our secret. 


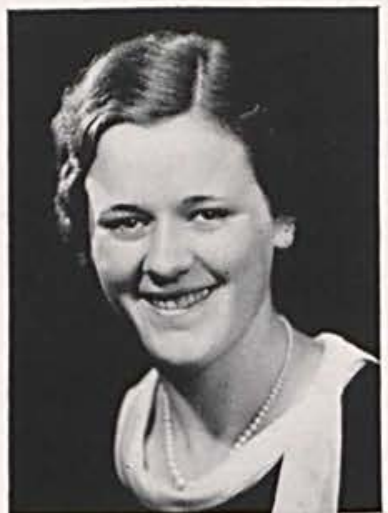

HELEN BAKER

Secretary to the president Instructor in shorthand and typing.

Of course, this case is hypothetical. If our brother be an engineer, we may follow that vocation. Our father may be an electrician and to that we may turn.

Now the result of all this is that we do not follow any objective, scientific basis of vocation choice. If this be true of college graduates, how much more true it is of others. So chance becomes our vocation-determining force, and society must run the risk of our becoming round pegs in holes of decidely different description.

The ideal is not difficult to imagine. Put every person into the job which will be mutually beneficial to him and to society; put him there as early in life as will be consistent with thorough training. But how is it to be done? Phrenology was a master stroke in this direction, except that is was too good to be true. So we have thrown Phrenology into the ash heap and no longer place any faith in it as a basis for vocational classification.

Is there nothing, then, to which we may turn as a guide for sorting out this conglomerate mass of youth which graduate from our schools and colleges? Apparently there is none yet.

But that does not mean that we must continue to let chance hold the balance of power. The beginnings are being made for a definite, scientific movement toward efficient vocational guidance. We have psychological authorities, who can quickly analyze the youth's aptitudes and desires, and who know the fields of activities offered in our complex civilization. These specialists can become sound counselors for us who hesitate almost to the point of being lost. They form the nucleus for an efficient vocational-planning system. We must plead for more such experts and for more strength to their arms.

\section{Normal Department}

Cedarville College has gained honors and high standing in many fields during her history, but in no line of endeavor is her record more notable than in the normal department. Probably no other teacher training institution in the country can point to such a high proportion of successful grade-school, high-school, and college teachers among her graduates.

This brilliant record is due to measures that assure the prospective instructor of being thoroughly qualified to assume his responsibilities, well-grounded in the basic acquirements, and highly trained in the fields of specialization which he may choose. That this high standard of preparation is recognized by authorities in the teaching profession is demonstrated by the department's remarkable success in placing its graduates. Cedarville College alumni can be found in countless townships in Ohio and surrounding states, and everywhere they are popular with pupils and parents alike.

Most of the credit for the showing made

CHURCH ON COMMENCEMENT DAY, MAY 1932

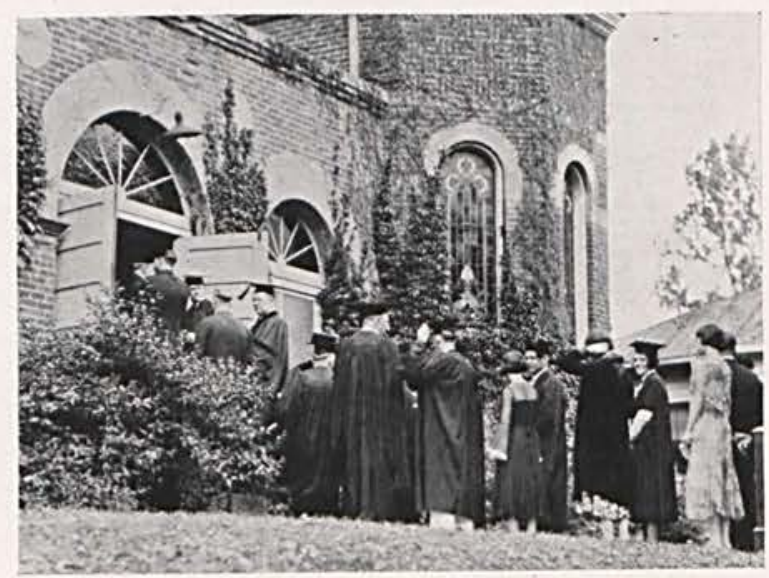


by Cedarville's normal department during the past few years is due to Prof. Hostetler, the head of the department. He possesses a keen, analytical mind that finds wide range for expression in giving individual criticisms to the student teachers. Also, he is endowed with the infinite patience necessary to help his students deal with their many problems. Every recent graduate of the College counts him a wise counselor and a true friend.

\section{Rev. Guthrie}

The college greatly appreciates the interest that Rev. Guthrie, pastor of the local Presbyterian Church, has taken in our various activities throughout the past year. Rev. Guthrie came to Cedarville last spring, having just previously completed his resident requirement work at the Edinburgh University, Scotland.

Rev. Guthrie graduated from Grove City College in 1925, and from the Western Theological Seminary in Pittsburgh in 1929, and after serving a year as assistant pastor at the First Presbyterian Church of Indianapolis, went to Edinburg to work on his Ph. D.

Since coming to Cedarville he has been closely allied with our school, serving as Professor of Ethics and Apologetics, both during the regular term and summer school. and as religious worker among the students.

\section{Dr. Ray}

Dr. Ray, we're sorry we can't claim you s a full-time professor. You come here to our institution, your Alma Mater, and teach us the important things about living healthy, disease-free lives, and eliminating disease from humanity's ills. We're sorry you can not be with us daily, but our gain would be the community's loss; so maybe 'tis best so.

\section{Miss Waddle}

After graduating from Cedarville College with highest honors last June, Miss Martha Waddle is back in school this year, taking advanced work and acting as assistant in Prof.

$$
\text { Y. W. C. A. }
$$

First row: C. Brill, Bisdorf, Labig, Cultice, O. Brill, Pyles, Watson, Spahr, West; Second row : Dean, McCallister, Walker Patterson, Lunsford, Smith, Atchison, Bradley, Watkins, Craw ford, Gordon, M. MeLaughlin, Linton, Probasco, Henry, Guthrie : Third row: Turnbull, Harbaugh, Chenoweth, Straley, Baker, Prof Angevine, F. McLaughlin, Bennett, Corry, Corbin, Hartman, Knoop, Basore, Berk, Wham; Fourth row: MeCallis ter, Mount, Robe, Prof. Work, Hostetler, Coulter, Ford, Waddle,

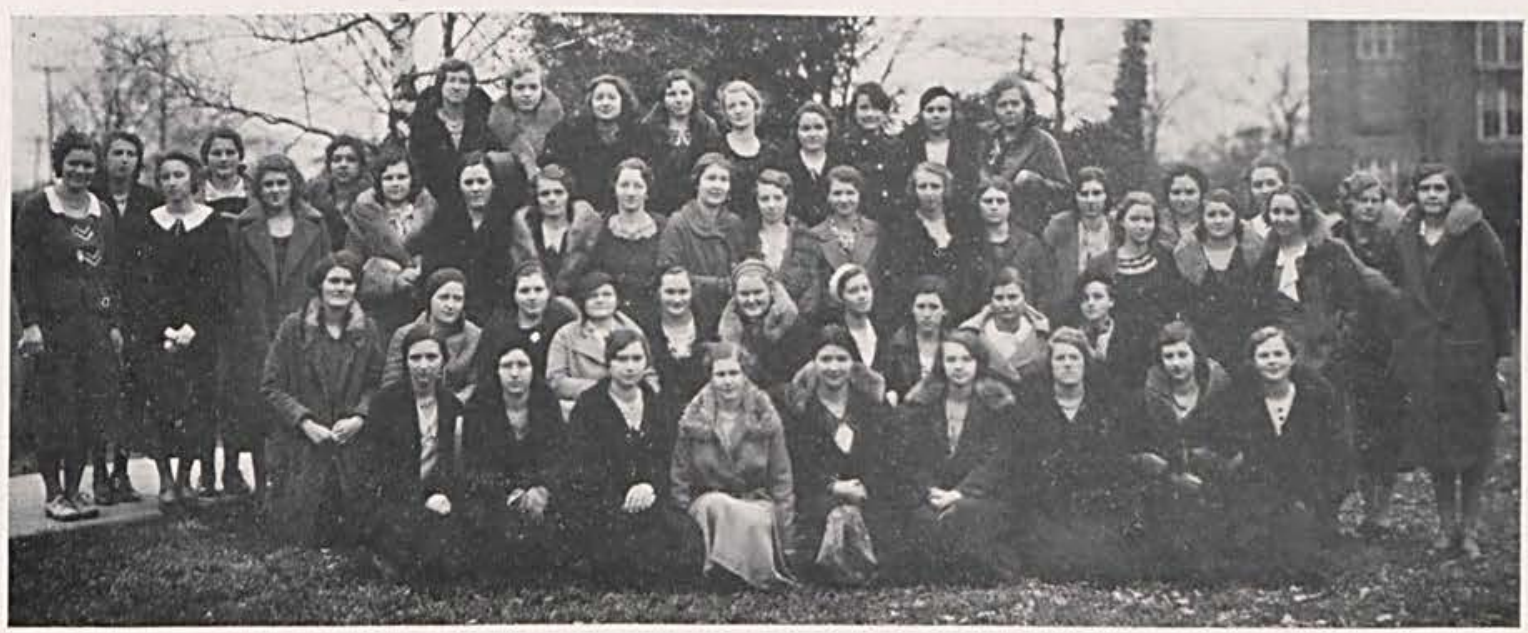


Hostetler's and Dr. McChesney's departments. Her work the first semester included the teaching of Class Room Management; during the second semester she has had no regular instructorships, but has assisted in logic and Greek whenever Dr. McChesney has been absent.

Miss Waddle's scholastic record in Cedarville College was very exceptional, and she has proved herself just as excellent an instructor as she was student.

\section{Y.M. C. A. and Y. W. C. A.}

So similar are the Y. M. and Y. W. C. A. in organization, character, and activity, that they can well be considered in one article. It is difficult, in the brief course of a few hundred words to review all of the many events and activities that have transpired in " $Y$ " circles this past school year, Most of these events are covered elsewhere in this publication, and hence these lines will deal more with the general nature an organization of the Y. M. C. A. and Y. W. C. A.

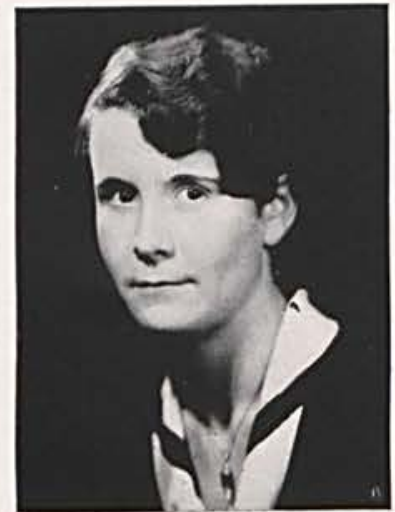

DORIS SWABY

Cedarville, Ohio

Miami University 3 ; Class Officer 2; Glee Club 1; Band 1. 2: Mock Wedding Groom 4; Basketball 1, 2, 4: Cedar Day Queen 4; Class Play 4: Cedrus Play 2: Cedrus Staff 2.

Both these organizations are, of course, affiliated, with the state-wide organization of the same name. Every year both groups send a specific financial contribution to the state offices and in return, secure the blessings of the wider contacts thus afforded.

At Cedarville all students are identified with the Y. M. if they be men or the Y. W. if they be women. All meetings are attended by the students, the regular meetings being on Wednesday morning of each week, supplanting the usual "chapel" for that day.

Primarily religious in nature, these meetings invariably include sacred singing, scripture reading and prayer. Announcements made, a program usually follows. Great is the variety of such programs, for they vary in length from a few to a full thirty-five or forty

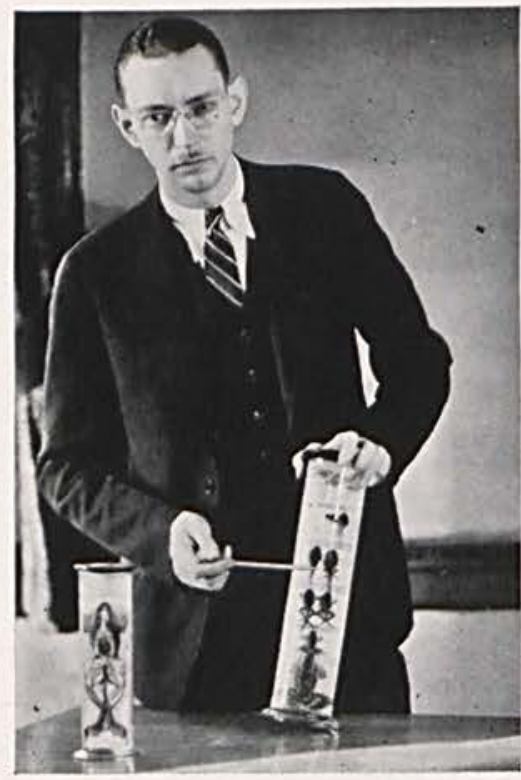

Dr. HAROLD E. RAY

Professor of Anatomy and Hygiene minutes. Similarly, their nature is never twice the same. Frequently outside speakers are arranged for and usually this means a joint "session," both men and women meeting as a combined audience. The local pastors of Cedarville Churches generally bring us messages of thought and inspiraction. Likewise, the past year's programs included Rev. Simester of Trinity Methodist Church in Xenia, Mrs. White, editor of $t$ he Women's Missionary Journal, Mrs. Ruth Hess, a member of Cincinnati's visiting teachers' staff, the Wiiberforce Male Quartette, Rev. French of Clifton, besides members of our own faculty and others yet to serve beyond the time of this writing. Our own talent is utilized, especially upon programs celebrating various holidays.

The control of each of these groups is vested in a cabinet. This year the Y. W. cabinet included Viola Harbaugh, president; Doris Hartman, vice-pres. and program chairman; Glenna Basore, secretary and treasurer; Jane West, hostess; Eleanor Bull, social chairman; Mary Catherine Probasco, membership chairman; Lois Cultice, financial chairman; Nina Stevenson, social service chairman; Mary Eleanor Ford, world affairs chairman; Carolyn Brill, pub- 


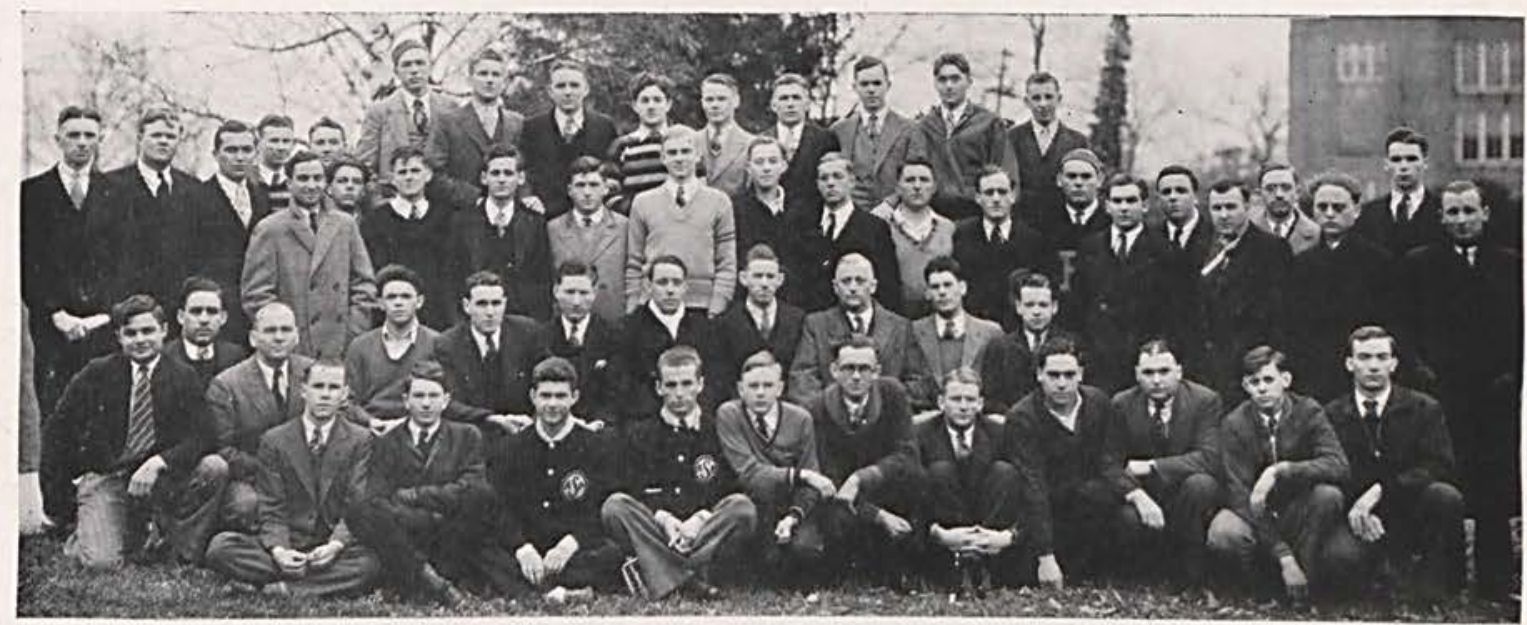

Y. M. C. A.

First row : Richards, Nelson, Hargrave, R. Ross, Buehler, Cash, H. Murray, Miller, James, Christian, Ferguson : Second row: Fox, Scott, Prof. Hostetler, Mills, Free, Bost, Harriman, P. Garlough, Prof. Steele, Donaldson, Hutchison; third row: MeLaughlin, Trubee, Ensign, Tindall, Kitchen, McCallis ter, McKnight, Meyers, L. Ross, Finney, Chamberlain, Glass, Rife, Kenfield, E. Spencer, McHenry, R. Murray, McNamee, J. Murray, Prof. Kuehrmann, Ferryman, Taylor, Brigner: Fourth
row: Thomas, Reid, Linton, Cappola, Thompson, Moorman, Kilpatrick, C. Spencer, V. Garlough.

licity chairman; and Miss Angevine, faculty adisvor. Officers recently elected for the coming year are Jane West, president; Doris Hartman, vice president; and Carolyn Brill, secretary-treasurer.

The Y. M. C. A. cabinet included Preston Garlough, president; Clyde Hutchison, vice president; Joseph Free, program chairman; Charles Bost, assistant program chairman; Robert Harriman, secretary; Arthur Donaldson, treasurer; John Mills, social chairman; and Prof. Kuhermann and Steele, faculty advisors. The new cabinet consists of Walter Kilpatrick, president; Homer Murray, vice president; Arthur Donaldson, program chairman; Carl Ferguson, assistant program chairman; Wm. Reid, secretary-treasurer; Stewart Kitchen, social chairman; A Cappola, publicity chairman; and Profs. Steele and Ault, faculty advisors.

\section{Committal Service of the Y. W. C. A.}

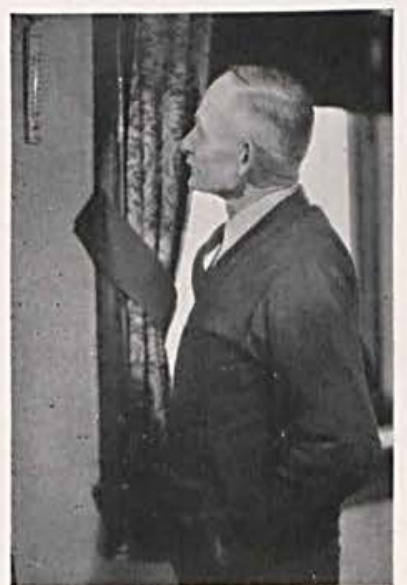

FRANK OWENS

The Y. W. C. A. held its annual committal service in the Presbyterian Church during the Thanksgiving season.

The girls, dressed in white, entered the church singing "God is Our Refuge and Our Strength." The church, dimly lighted and beautifully decorated with ferns and flowers, furnished a very impressive setting for the program.

The president, Viola Harbaugh, presided over this service, and opened it with these beautiful lines -

"Hope giveth unto us

Another year.

Adventure is

To follow the climbing Good, By thorn and beast withstood, To heights of brotherhood Through dim to clear.
God giveth unto us

Another year,

All luminous

With Him, our shining source, Divine redeeming force, Of life's bewildered course Still charioteer." 
This service is one in which the new members pledge themselves to live up to the ideals of the Y. W. C. A., and the old members renew their pledges of former years.

After every girl had lighted her candle from those about her, came the recessional by candle light, the girls singing, "Follow the Gleam."

This service was written by Frances Mc Chesney for the Y. W. C. A. of Cedarville College. It is a very impressive service and is kept sacred in memory of her.

\section{Baccalaureate and Commencement}

A year book would be incomplete, indeed, without some mention of these most important events of Senior Week. Both these affairs of 1932 were most impressive and beautiful, the first being held Sabbath evening, May 29th, and the latter at 10 A. M., the morning of June 3. Both were held in the fine old Presbyterian Church.

Filing in reverently to the strains of lovely organ music, the graduating class seated itself directly before the pulpit, their black caps and gowns presenting a very dignified and ceremonious appearance. The sermon was preached by Dr. McChesney, our beloved president, a custom which has become almost traditional at Cedarville. As usual, the sermon was filled with inspiration and worthy counsel. Another never-to-be-forgotten event had come and gone for seventeen college seniors.

Someone, possibly an advertiser of jewelry, has said that college commencement and one's wedding day were the two most important events of one's lifetime. Could we have been among those happy graduates who received their diplomas at the Commencement of 1932 , we are sure we would not have have doubted the former, at least, a more pleasing, impressive exercise could hardly be imagined.

First, the Commencement procession, formed at the library, and led by Viola Harbaugh and Preston Garlough, officers of the Junior class, marched to the choir loft of the Presbyterian Church. Dr. Eigenshenck, organist of the 2nd Presbyterian Church of Chicago, provided the unsurpassable organ music, which was a distinctive feature of this occasion.

The address was delivered by the Rev. Dr. McLennan of the Shadyside United Presbyterian Church, Pittsburgh. He brough a very fitting and forceful message with words of wisdom and inspiration for all who attended.

Next, degrees were conferred, and President McChesney presented the diplomas, accompanying each with a brief but eloquent statement to the recipient.

Anyone who was included in the large audience will never forget the impressive atmosphere which characterized that commencement scene. The sunlight of a perfect June morning through the gorgeous stained glass windows of the church seemed to harmonize with the exquisite organ music.

Truly, Commencement 1932 has thus far been unsurpassed.

\section{The Bible Reading Contests}

As has always been the case in the past, the outstanding feature of the Bible reading contests this year, was the ability and sincerity with which the entrants read and interpreted their passages. These annual events always attract huge crowds to the First Presbyterian Church, and the audiences never fail to leave with a deeper realization of the value of a Christian education in seeking out the hidden truths of the Word.

At the women's contest, held April 9, the Misses Luella Robe, Doris Hartman, and Eleanor Bull were adjudged the winners; Robert Harriman, Walter Kilpatrick, and Clyde Hutchison were chosen by the judges in the men's contest, November 20. 
Special music was provided for the contests by the Girls' Glee Club, the Girls' Quartette, and George Moody.

To Professor Steele should go most of the credit for the continued success of these annual readings, made possible through the generosity of Miss Margaret B. Rife and Dr. C. M. Ritchie.

\section{Frank Owens}

What it takes to keep the machinery in the basement humming, Frank Owens has. Above all he possess that supreme virtue which should characterize everyone who fills such a responsible position, reliability. We've seen him grimy with coal dust in his valiant effort to "make things hot for us"; we've seen him with perspiring brow as he strove to keep some acres of luxuriant grass subdued with a hand lawn mower.

Frank, if we were poets, what kind verses we'd write about you. 


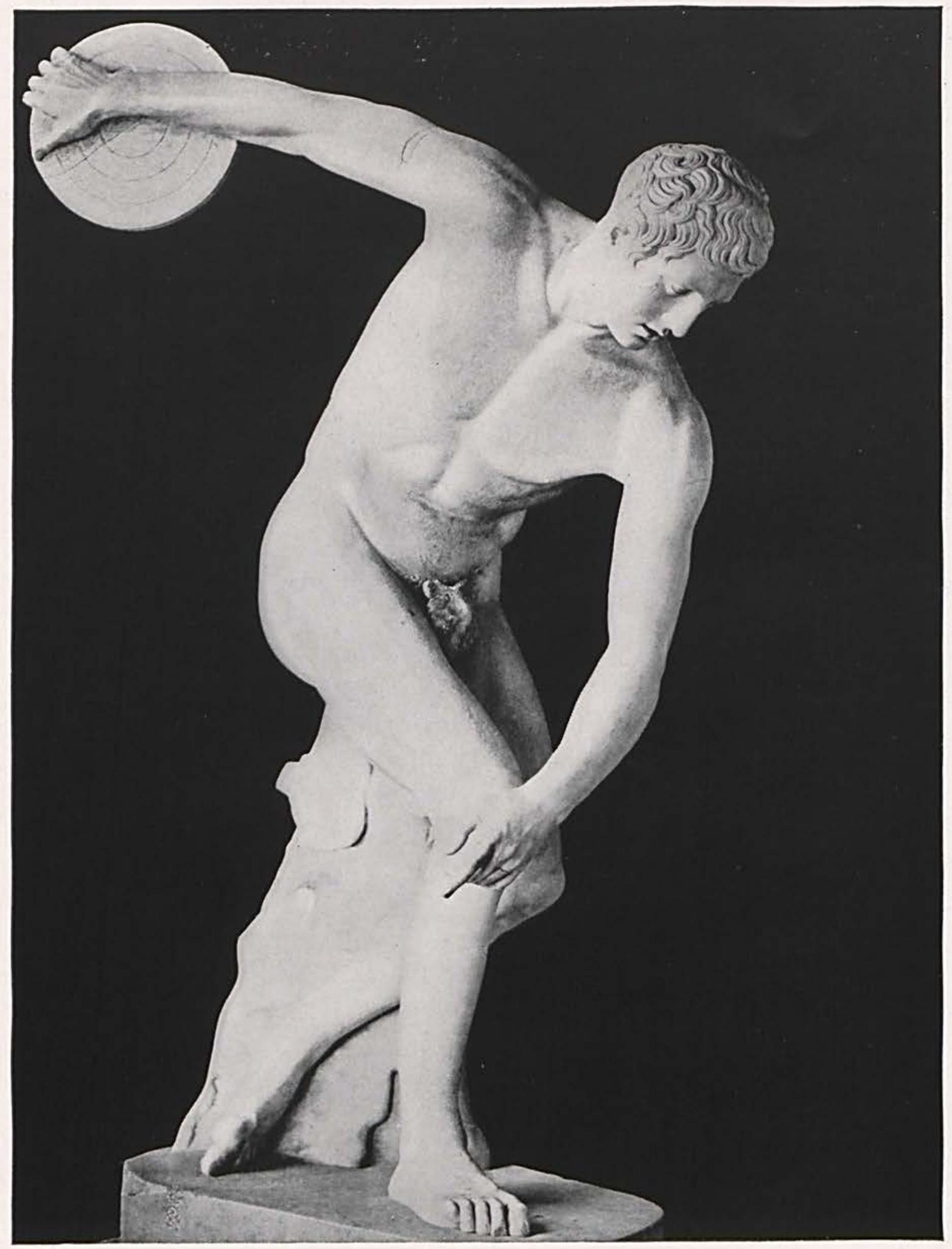




\section{CHAPTER FIVE}

\section{Character}

\section{DISCOBOLUS}

"Discobolus" is a work of the Greek sculptor, Myron, who lived in the fifth century B. C. There are several copies of the statue which are found at the Vatican, the Massimi Villa at Rome, the Capitoline Museum at Rome, and the British Museum.

"Discobolus" is wonderfully effective, and we feel as if we must see the throw made, and the dense muscles relaxed, before we can leave it. It is an example of the highest Greek art in the representation of the physical frame and difficult action."

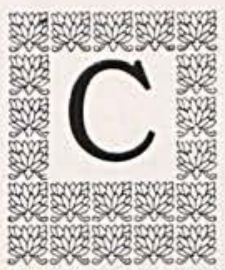

HARACTER has been defined as a perfectly educated will. It is moral excellence, power, and influence.

Every one should hold the possession of a good character as one of the highest aims of life. Young people, as they start in life, should regard character as capital, much surer to yield full returns than any other form of capital, unaffected by panics and failures, fruitful when all other investments lie dormant.

Character is not achieved over night, created at will, "caught," or "bought." It is a product of sanity and right living. It is founded and maintained by constant performance. Character of the real sort is quite like health and happiness. It should need, and receive very little direct attention, but appear like the fragrance of a flower in the process of normal and vigorous living.

Character is formed by a course of actions. Each one of us is building character every day; and every act of life should be a step nearer the goal. If day by day we are careful to build our lives with pure, noble, and upright deeds, at the end we shall be the possessors of a fair temple, honored by God and man. The myriad forces within us are incessantly developing. A great structure is going up, story by story, although we are not conscious of the process. It is character-a building that must stand; so we must be perfectly sure that there is a secure foundation that will endure the storms and turmoil of life. But as one leak will sink a ship, and one flaw break a chain, so one dishonorable, 
untruthful act or word will leave its imprint and have its influence on our character.

We are given our minds; we make our characters. The powers necessary to make character are comparable to a handful of seeds. Plant the seeds and tend them well, and they will make a good orchard. Cultivate the powers and harmonize them well, and they will make a noble character. God gives the mind; man makes the character. The mind is the garden; the character the fruit. A subtle thing is character; a constant work is its formation. A good character is a precious thing, above rubies, crowns, gold or kingdoms, and the work of making it is the noblest labor on earth.

One great factor in determinging character is what one really is. Then when one finds out what he is, he must catch a vision of what he might become and improve himself by his thoughts and actions, because thoughts make habits and habits make character.

Habits are but assembled bundles of settled ways of doing things, and we are merely the reflections of our habits. Habit can be man's best friend or his worst enemy; it can exalt him to the highest pinnacle of virtue, honor and happiness or sink him to the lowest depths of vice, shame and misery. Metastasio entertained so strong an opinion as to the power of repetition in act and thought, that he said, "All is habit in mankind, even virtue itself." We must cultivate good habits; for it follows that men of fine character are men of fine habits.

Since thoughts make habits, one's thoughts should be pure and worthwhile. One should think clearly and try to control his thoughts. Evil thoughts are dangerous enemies and should be repulsed at the threshold of one's mind. All great men are thinkers; otherwise they would not have attained greatness. They form new ideas and opinions. They do not accept the thoughts of others, but organize their own and then become famous by putting these thoughts into action.

The value of character is the standard of human progress. The individual, the community, the nation proclaims its standing, its advancement, its true wealth and glory by its reliance on character. That man or nation who lightly esteems character, is low, groveling, and barbarous. Wherever the formation of character is a secondary consideration, sensualism and crime prevail. He who tries to discard his proper character to assume what does not belong to him is usually ignorant of both the character he leaves and the character he assumes. Theodore Roosevelt's strong statement of many years ago, becomes a burning truth today, "Character is, in the long run, the decisive factor in the life of individuals and nations alike."

Character creates confidence in all men regardless of station of life. It was said of the first Emperor Alexander of Russia that his personal character was equivalent to a constitution.

Franklin attributed his success in public life not to his talents or powers of speaking, for these were but moderate, but to his known integrity of character.

Every true and noble character is sincere. He is free from hypocrisy and pretense. There is no folly in the world because outwardly he pretends to be a good character,

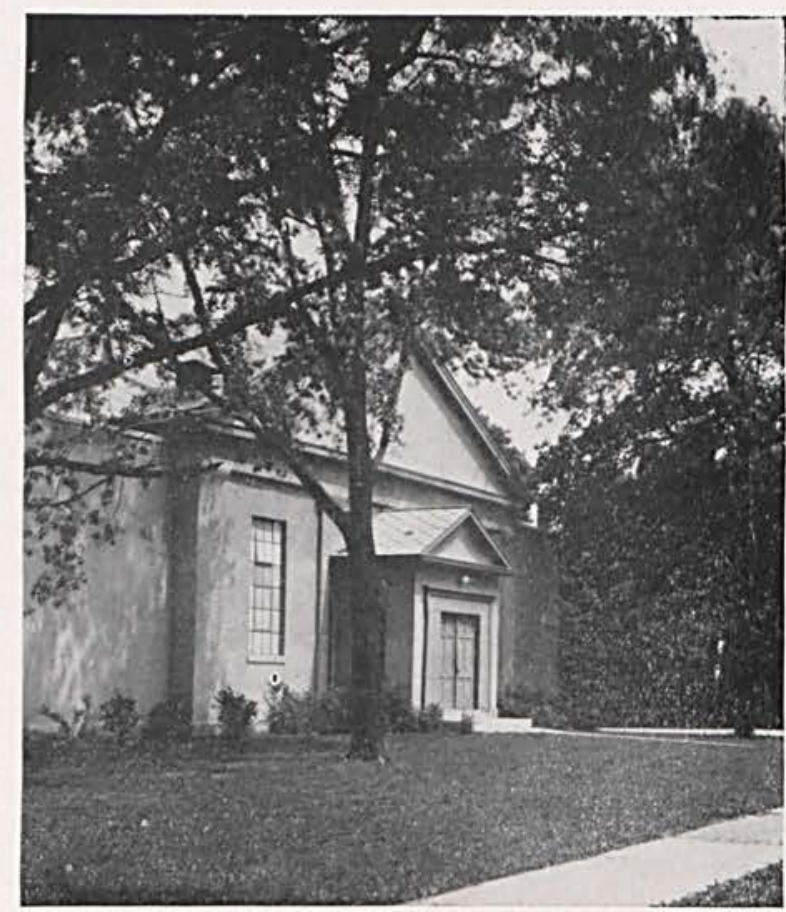

ALFORD MEMORIAL GYMNASIUM 


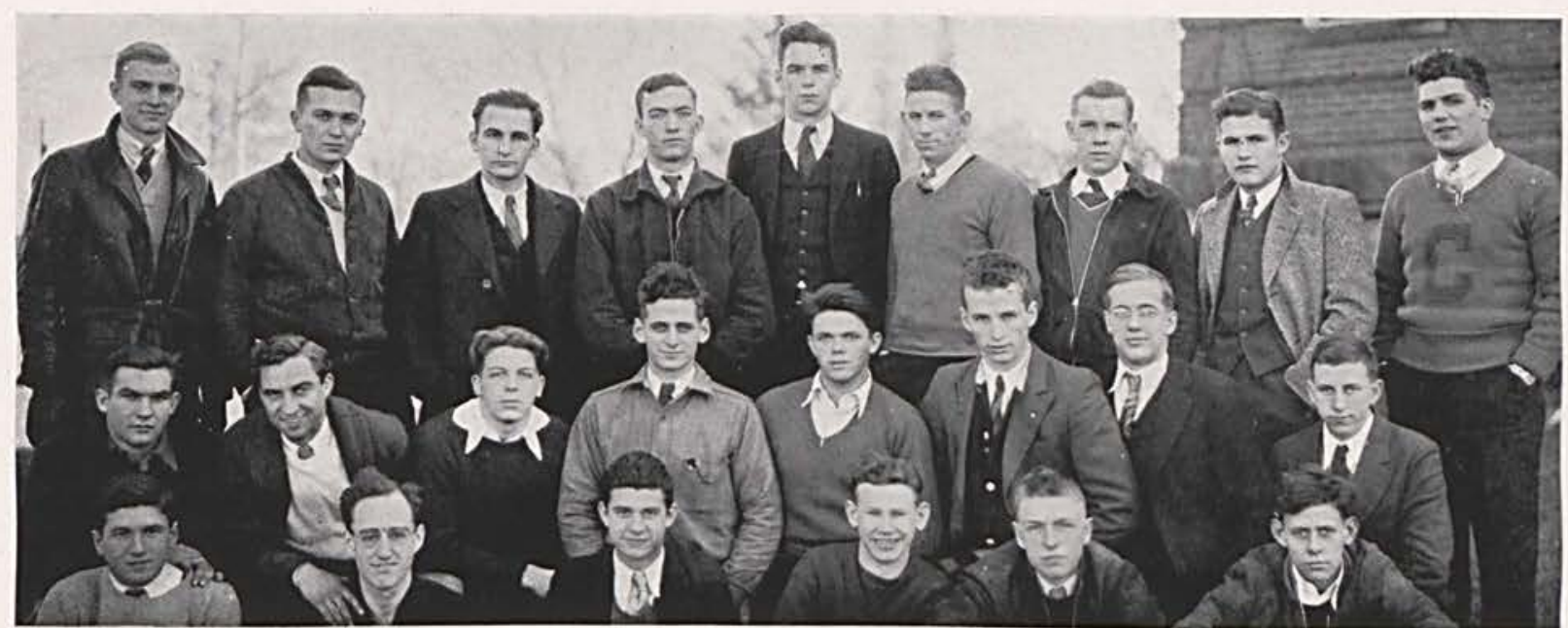

FOOTBALL TEAM

First row: Finney, E. Spencer, mgr., Hargrave, Tindall, Thomas, Christian: Second row: R. Murray, Kitchen, MeKnight, L. Ross, Mills, R. Ross, Rife, V. Garlough: Third row: Chamberlain, mgr., Ensign, Coach Ault, Ferguson, Taylor, P. Garlough, Richards, Tedrick, Irons, assistant coach.

but inwardly he is the opposite-a character that is vile and sinful. A paste diamond, large and brilliant, may gain the admiration of the unwary spectator, but it cannot respect itself.

A professional athlete who has posed as an amateur may be carried on the shoulders of a college crowd in triumph, but he knows that he is not sincere, and he does not respect himself. Ruskin tells us that in oue corner of a Venetian church he found the statue of a great leader, with the side toward the audience elaborately finished, while the side toward the corner was left rough. On the public side, the forehead was carefully wrinkled, the cap beautifully chased, the ermine robe scrupulously imitated; on the dark side the marble was unwrought. "Now," says Ruskin, "comes the very gist and point of the whole matter. This lying monument is at least veracious, if, in nothing else, in its testimony to the charcter of the sculptor. He was banished from Venice for forgery in 1487." How many such living models are there in the world to-day? We see how the insincerity of the sculptor's character was represented in his work. Be sincere. Do your tasks neatly and completely-for you, too, may show your character through faultless work.

Ambition is also an important factor in determining character. Through ambition we overcome obstacles and scale great heights. No goal is too indistinct for the ambitious person. As a young lad, Paderewski longed to be a great musician. His teacher told him his thumbs were stubby and his fingers short, that he had better learn to play a horn. But the boy had visions of some day playing the piano before nobility in grand concert halls; and he would not be side-tracked. He dreamed and he practiced. At his first public recital he forgot, became badly confused and was compelled to make up parts of the music. At sixty, a man of noteworthy character, he was the greatest living pianist, and the first President of Poland. Through his visions and ambitious practicing he overcame obstacles and reached his goal.

The trait of kindness should be found in every one who hopes to attain a good character. A word of kindness is a seed which, when dropped by chance, produces a flower. Kindness makes sunshine wherever it goes; it finds its way into hidden recesses of the heart and brings forth golden treasures. Write your name by kindness, love, and mercy on the hearts of the people with whom you come in contact year after year, and you will never be forgotten. Kindness is stored away in the heart like rose-leaves in a chest, 


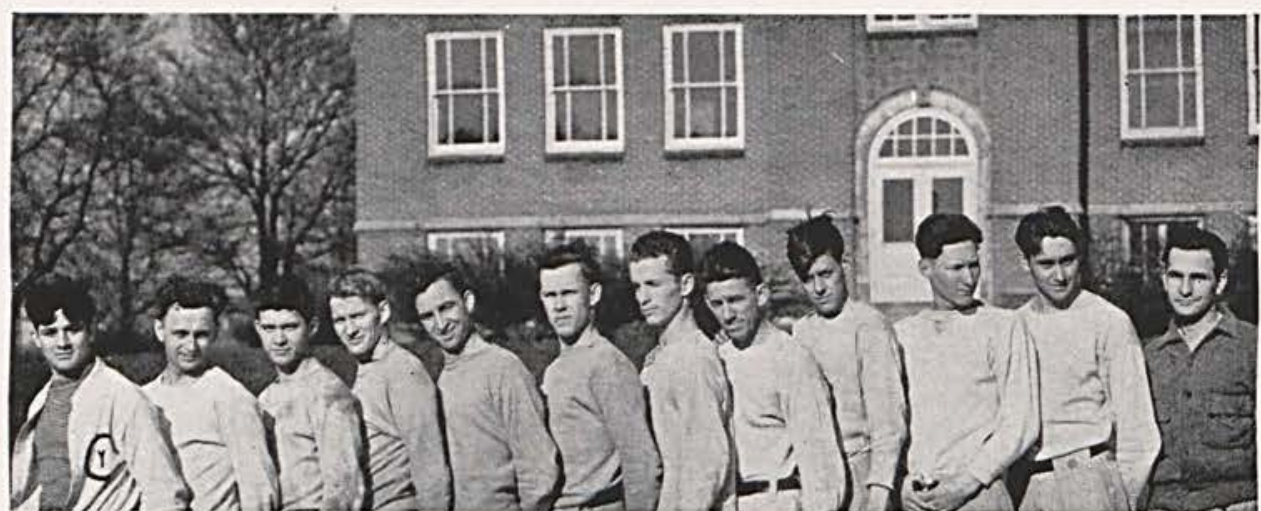

BASKETBALL TEAM

Cappola, Paxton, Hargrave, H. Murray, Kitchen, Richards, R. Ross, P. Garlough, Christian, Bost, C. Spencer, Coach Ault. to sweeten all surrounding objects.

Kindness is $\mathrm{measured}$ in terms of $\mathrm{th} \mathrm{e}$ spirit $\mathrm{w} \mathrm{h}$ i $\mathrm{c} \mathrm{h}$ prompts the act, rather than by the importance of the act itself.

Have respect for yourself as well as for the f e e lings and

opinions of others; have respect for law, because law is the recorded attempts to preserve peace, tranquility, and order; have respect for God, who has omnipotent power.

Never be cast down by misfortunes. If a spider breaks his web he will mend it over and over again. When the sun goes down, look up at the stars; if earth is dark, keep your eyes on heaven. With the presence and promise of God we can endure anything; we should press onward, and never falter or fear.

It was that sturdy, western pioneer, Horace Greeley, who at the end of a very checkered career, said, "Fame is a vapor, popularity an accident, riches take wings, those who cheer to-day will condemn to-morrow, only one thing endures-character."

\section{-Lois Cultice.}

\section{A Word From Coach}

At some time or other every subject and every department of a school or college is called upon to justify its existence as a part of that college or school. This is especialiy true of the so-called special objects.

In the past, the objective of a college was the teaching of a certain amount of knowledge, or facts. Educators of the present have broadened this objective to include a large amount of social training; that is, training in honesty, aggressiveness, fair play, emotional control, the advantageous use of leisure time, and the other social characteristics of this kind.

It is in this field that athletics and physical education play so large a part. In no other subject does the teacher find so many opportunities for social development of the student. The success of physical education and athletics in the school has been so great that they are considered a necessary part of every well balanced educational program.

\section{FOOTBALL, '32}

At the opening of the current football season, thirty men answered the call of the new coach, J. W. Ault. Of this number only a few were experienced in college football. The number was later limited to two teams.

The inexperience of the players and the extremely difficult schedule prevented the season from being a very successful one. The team was probably the lightest in weight that has ever been put on the field by any college. Beyond doubt, this was the contributing factor in the defeats of the team. Over half of the opposing teams were entirely out of our 


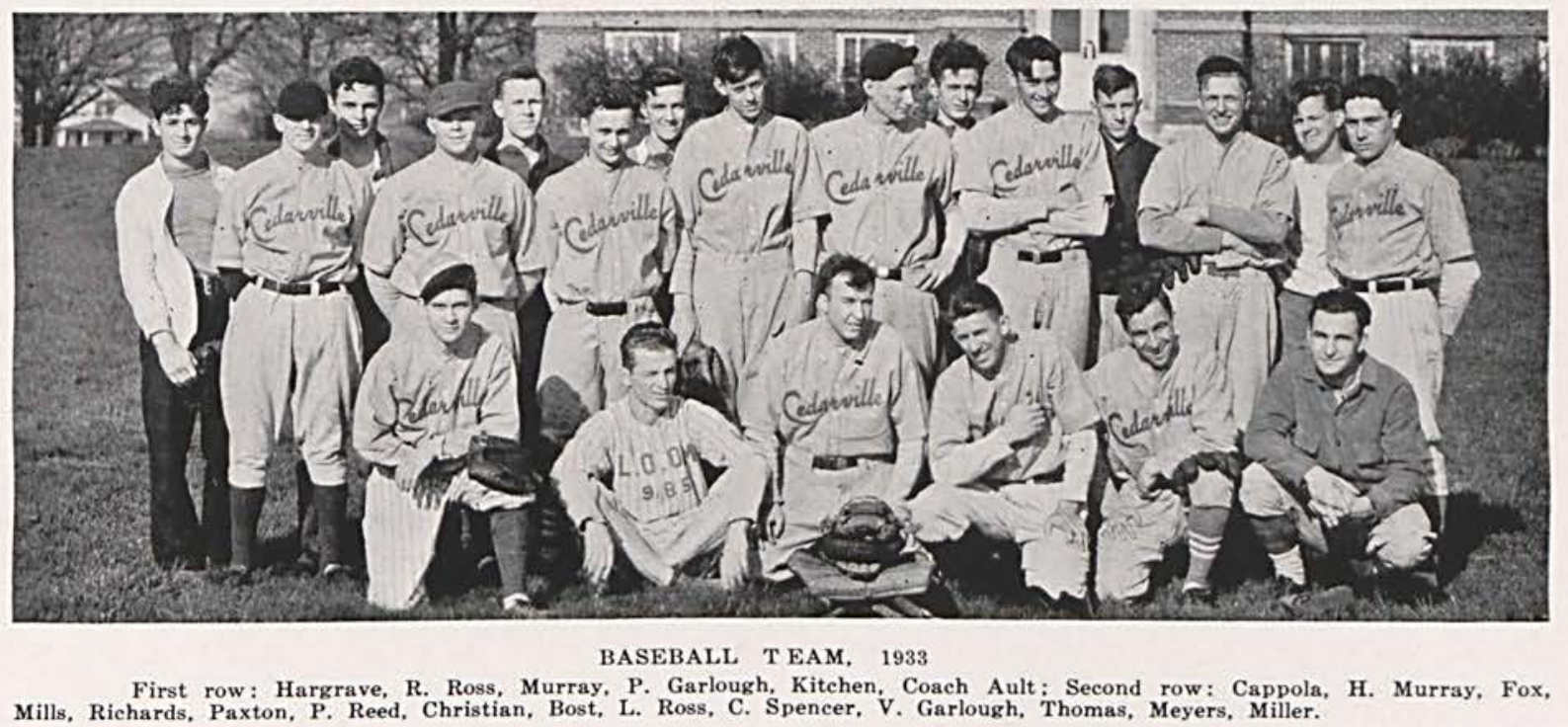

class, some of them on par with such teams as Holycross and Dartmouth. Cedarville made a very creditable showing against the teams of its own caliber.

Next season's prospects appear to be much better. The team loses only two men through graduation, and the schedule is more in accordance with the size of the college. So let's all boost the team and look forward to a more successful season in ' 33 .

\section{Basketball}

The Basketball Season of 1932-33 marked the advent of Cedarville College's Basketeers into the league competition of the Northwest Ohio Conference. That the entrance into this league will have a marked effect on basketball at Cedarville in the future is undoubted, for it is league competition and the desire to be at the top of the list that makes every player give his utmost for his school, his team, and his coach.

Cedarville finished fourth in the Conference standing for the season 1932-33 with a record of two wins and six losses. Although the team's percentage is not so impressive, it in no way gives an adequate indication of the efforts of the coach and team. Both labored unceasingly to bring basketball laurels to the college.

Much credit is due to Coach Ault for his efforts. As the new coach, he started the season, knowing little of the ability of the players, but little by little he selected his teams so that by the end of the season Cedarville was giving all opponents a fight.

The hopes for future teams are particularly bright as the year 1932 saw the coming of a considerable number of freshmen of exceptional ability. The sophomores and juniors also presented their show of material. The seniors gave four members to the squad and they will be lost from the teams through graduation. However, we can readily see that their places will be capably filled by some of the newer talent.

Prospects for the 1933-34 basketball season are unusually bright. To Coach Ault and his boys we wish success and may they crown the Northwest Ohio Conference basketball record with Cedarville.

\section{Girls' Basketball}

In the beginning R. R. S. created a B. B. team. It was without form and void for most of the season and gloom (R. V.) was over the spirits of those who watched us. 


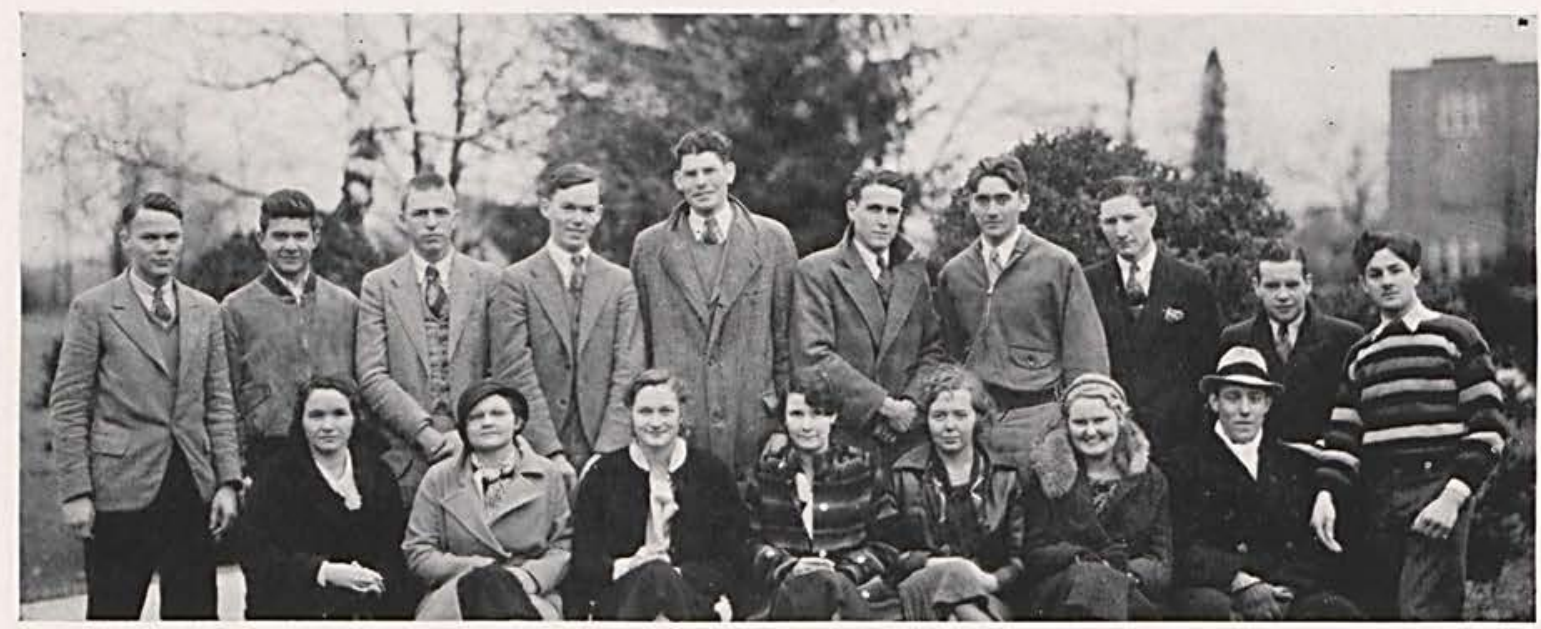

TENNIS CLUB

First row: Auld, Lunsford, Smith, Swaby, Bull, Atchison, Harriman; Standing: Thompson, Hargrave, Thomas, Kilpatrick, Donaldson, Free, Spencer, Bost, Hutchison, Cappola.

And the coach said, Let there be light," and there was light for we had four forwards-Auld, Linton, Spahr, and Watson. And the coach saw the forwards that they were good and divided the forwards from the guards who were Mount, Crawford, Swaby, Lunsford, and Watson (by virtue of ability to play equally well the positions of forward, guard, and in times of necessity-center).

And the evening of the first game we played Cedarville Independents-winning by a few points.

And the evening of the second game we played the same independents. By virtue of an additional player-one from Springfield All County Team-we lost to the melody of $12-9$.

About the evening or was it the morning? of the third or was it the fourth game? we attempted to play Bellbrook.

After that game a great light was set in the firmament-Curley Ross-to rule the team (and give instruction); he made the stars also.

Then one day we had a game-upper class vs. Sophs and Frosh. The upper class line-up was Smith, center; Cultice, Stevenson, Auld, Swaby-Tedrick and Tindall.

The Sophs and Freshmen included Crawford, Mount, Spahr, McAllister, Knoop. The rules were five man defense.

Two casualties occurred during the season. Madge went home at semesters and Linton, because of an injury gotten in H. S. a thletics, could play no longer. We missed them both.

There were several girls who helped us practice every night. Some recognition is due to them. There was Elaine Knoop, forward; Julia McCallister, center; Anita Corbin, forward; Marjorie Gordon, forward; Nina Stevenson, guard; Mary Lou McLaughlin, guard; Margaret Berk, guard; Maxine Bennett, center; Mary Catherine Probasco, guard; Janis Atchison, guard.

\section{Baseball, 1932}

Cedarville College had a very successful baseball season last spring. After making a rather poor showing at the beginning of the season, the team found itself, and the schools that were met later on in the season found a team well coached both in the 
GIRLS' BASKETBALL TEAM

First row-Crawford, Swaby, Spahr, Second rowLinton, Atchison, Lunsford, Smith, coach.

offensive and defensive departments of the game.

During the season we played two double header contests, with Hanover and Rio Grande, and we broke even in both cases. Our old rivals from Wilberforce were played twice, and we broke even with them. We lost to Hanover College by a score of 1 to 0 , which indicates the defensive strength of the tem. By winning from Wilberforce 14 to 13 the offensive strength of the team is well indicated.

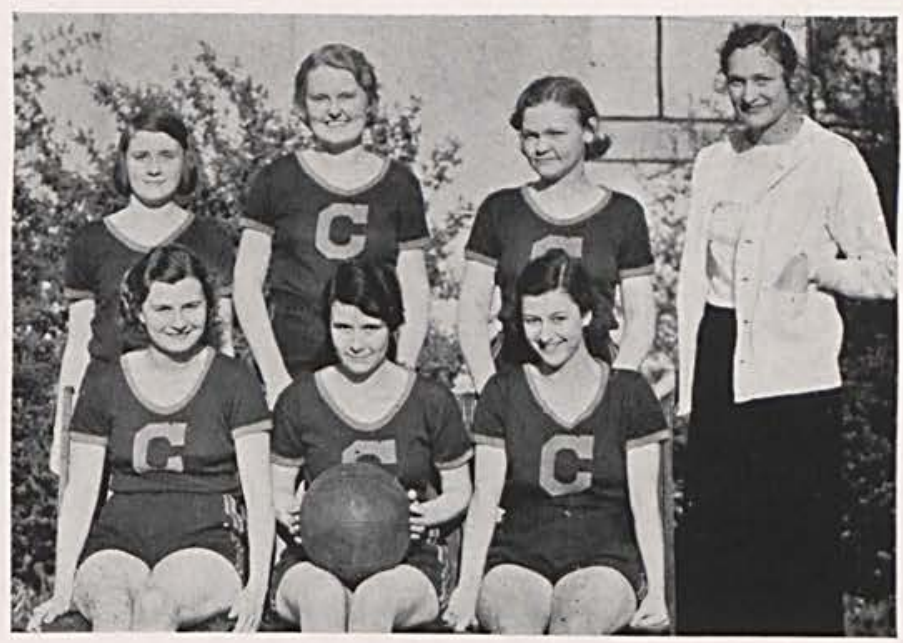

The burden of the pitching rested on the shoulders of Preston Garlough. Peter pitched some great ball and we are glad that he is back this year to carry on.

We lost Dutch Rife and Hap Rutan through graduation. Their places will be hard to fill, but with old men back and a number of men prospects in school this year, Cedarville should enjoy a successful season in 1933, under the able coaching of Mr. Ault.

The baseball squad wishes "Pops" Borst success in his new job.

\section{Tennis Club}

Tennis is annually entrenching itself more firmly as a favorite sport at Cedarville College, as is evidenced by the crowds that gather around the courts on every fall or spring day.

Last fall, intra-mural tournaments were held, open to all students, with over thirty contestants entered in one or more of the five classes. Although bad weather prevented the contests from being carried to a satisfactory conclusion, much interest was maintained all fall; and good-sized galleries cheered on the favorites and the dark horses in their matches.

Bob Wilson is coaching the varsity team this spring. Officers of the College Tennis Club are Kilpatrick, president; Wilson and Wilda Auld, managers.

So far the following schedule has been worked out:

May 3-Wittenberg at Springfield.

May $12-$ Bluffton at Bluffton.

May 17 -Wilmington at Wilmington.

May 13 - Findlay at Findlay.

May 16-Wittenberg at Cedarville.

May 22-Wilmington at Wilmington.

May 27-Bluffton at Cedarville.

Dates for matches with Antioch, and the return match with Findlay, are yet to be settled. The team also may be sent to an invitational tournament at Bluffton, May 19-20, in which Wittenberg, Dayton, Toledo U., Defiance, Bowling Green, and other schools will be participants.

\section{Cheer-Leaders}

No greater incentive to hard playing exists than a lively, enthusiastic student cheering section. Much credit for the scrappy showing Cedarville's teams made in their home 


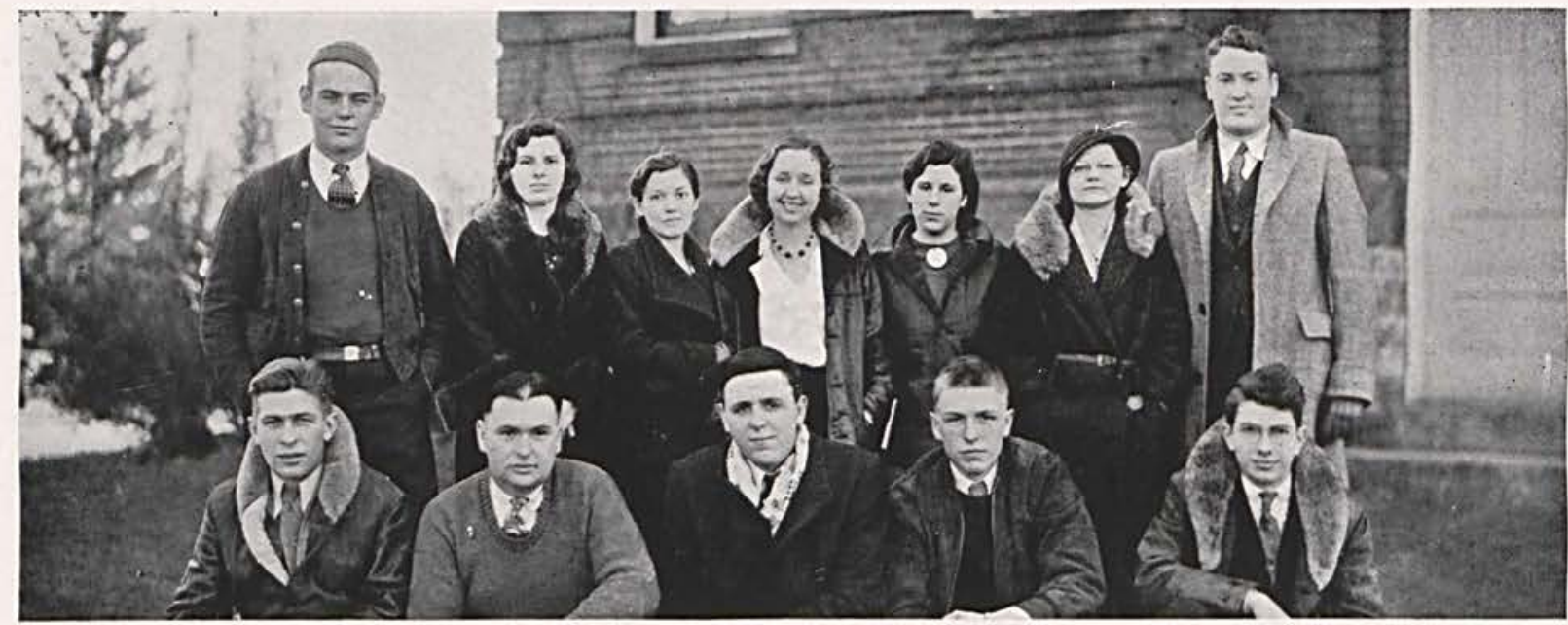

"X" CLUB

First row: Moorman, James, MeNamee, Thomas, Nelson; Second row: MeHenry, Ford, Bradley, Probasco, Watkins, Lunsford, MeCallister.

contests is due to the cheer-leaders, Mary "P at" Crawford and Edward "Ted" Tedrick, who were responsible for the "organized enthusiasm." The student body, led by these peppy young people, showeri more real school spirit than has graced Cedarville College for many years.

\section{Homecoming Banquet}

One of the most successful Home-coming Banquets in the history of the college was held in the Alford Memorial Gymnasium, on the evening of February 9, 1933. Eighteen classes were represented, and a host of alumni, students, and other friends of the college were in attendance.

After the dinner served by the Ladies' A dvisory Board, President McChesney gave the welcome address. The college Mixed Ch orus and the Girls' Quartette entertained with several groups of song.

After the brief program was finished, the floor was cleared for action, and the annual Homecoming basketball game was played with Urbana University furnishing the opposition. The game was fast and furious, and a last-minute rally gave Cedarville a wellearned victory, bringing the Homecoming to an entirely successful close.

\section{Y. M. and Y. W. Get-Together}

The Get-Together held in the gym, September 15, started off with a bang. Everyone, upon entering the door, was given paper and pencil. Each was to see how many autographs he could obtain in a limited time. This get-acquainted stunt soon made the new students feel at home. The old gym rang with laughter as relay races, stunts, and various games followed.

Girls were given the names of songs which they were to sing until the boy with the same song found her, thus uniting the partners for refreshments.

A delicious lunch of fruit punch, apples, doughnuts, and candy was served. 


\section{Welcome Tea}

In accordance with an old school custom, the members of the Y. W. C. A. gave a tea in honor of the new girls, in the basement of the Library, September 12.

The following program of music and rea dings was enjoyed: a duet, Martha Waddle and Florence McLaughlin, accompanied by Eleanor Bull; a violin solo, Eleanor Bull; readings, Glenna Basore.

Miss Angevine, faculty advisor, and Lois Cultice served the guests wafers and tea.

The girls formed new friendships and ea gcrly looked forward to a year full of pleasant events and cherished fellowship in the Y. W.

\section{Y. W. C. A. Christmas Party}

An annual party, where the girls learned who had been sending them those cakes, pies, candy, letters, and other tokens of friendships, so mysteriously signed "Your Secret Pal," was held at the home of Eleanor Bull, December 20.

A beautiful Christmas tree, all trimmed with twinkling lights welcomed the girls. Packages of all sizes lay beneath the tree's protecting branches.

Games of various kinds in keeping with the season were played. The girls joined in singing old familiar carols.

Gifts were unwrapped and many a girl was surprised when she learned the name of her "Secret Pal."

A delicious lunch of fruit jello, little crescent cakes, and hot cocoa was served. Favors, small candles to throw out little flames of Christmas light, were given the girls.

\section{Guess Who and Who-Else}

The annual mock wedding of the Y. W. was held at the Alford Gym at 8:00 P. M. on April 21.

At one side of the Gym, the bridal arch was placed, decorated with green and white streamers and banked with ferns. At each side of the arch was strip of lattice-work adorned with trailing green vines and yellow butterflies.

With Dorothy Lunsford at the piano, an excellent musical program was given.

"I Love You Truly" was played on the violin by Eleanor Bull, and Lois Cultice sang "At Dawning" and "O Promise Me". Then to the strains of Lohengrin's Bridal Chorus, the groom, Mr. Guess-Who (Doris Swaby) and his best man (Nina Stevenson) together with the preacher (Florence McLaughlin) and the ushers assembled at the altar.

The bride's-maids-Mary Crawford, Beatrice Pyles, Jane West, and Doris Hartman-came to the altar, carrying bouquets of snapdragons, and dressed in pastel shades. Next came the flower-girl-little Mary Lou McLaughlin-scattering petals in the path of the bride. She was followed by the maid-of-hon or, Glenna Basore, wearing a rose lace gown and carrying pink and lavendar sweet peas.

The bride-And-who-Else-entered on the arm of her father-Luella Robe-followed by the little ring-bearer-Master Lois Bradley-carrying the ring in a daffodil.

The bride was beautiful in green organ die, with a long veil of the same shade. She carried a gorgeous bouquet of pink sweet peas.

Following the cermony, a reception was given for those present. The bridal party was seated at a beautifully decorated table and served bride's cake and ice cream. The

Page Forty-seven 
Junior girls ate of the traditional cake, and, as a result, Lois Cultice found the ring in her slice of cake, making her the bride of ' 34 . With a toast to Lois, the evening closed .

\section{The Mother-Daughter Banquet}

One of the happiest days of the year, in the life of a Y. W, C. A. girl in Cedarville College, is the day on which she proudly brings her mother to a banquet, prepared with loving hands.

The banquet in May, 1932, was no exception. I'm sure it was the very nicest one we have ever had. Almost every mother and da ughter were there. They were seated, youth and age, around four beautifully serviced tables.

Following is the menu of the dinner served by the members of the Y. M. C. A. Fruit Cocktail

Peas and Carrots

Creamed Chicken on Biscuit

Ice Cream

$$
\text { Cole Slaw }
$$

Escalloped Potatoes

\section{Coffee}

Cake

After being so delightfully refreshed, a splendid program was given as follows:

Music Eleanor Bull and Bernice Elias

Welcome Rachel Douthett

Response Mrs. J. S. West

Duet. Doris Hartman

Reading Glenna Basore

Solo Mary Ruth Wham

Address Mrs. R. M. Borst

Wilda Auld was Toastmistress

The memory of that evening's program, especially Mrs. Borst's beautiful message, will remain in our hearts always.

\section{Freshman Week}

"But, Mother, I know I have only been a way at school a few weeks, and that I had promised not to come home until Thanksgiving. You don't understand what a perfectly dreadful week I have just gone though. I will promise, though, not to get homesick when I go back, if you will just let me stay this one week-end." This was what a freshman girl who attended Cedarville College related to her parents when she returned home after Freshman Week.

"A week ago today, I noticed a crowd a round the bulletin board. I couldn't imagine what was the attraction. After I had nudged my way through the crowd. I read, 'NOTICE FRESHMEN!' in print so large you would think we were far-sighted. 'These rules must be strictly obeyed; strict penalty if broken'. Under this was a long list of horrible things for us to do.

"Do you remember when I wrote home and asked you to send me Tippie's collar and chain? We had to wear these articles all day. Every time an upper-classman came around, he would lead us like little pups. If they saw any fun in that, I certainly can't see where it was. This wasn't the worst, though. At least, it was not so bad as going without cosmetics of any kind and wearing the same print dress, all week. What a sight we must 

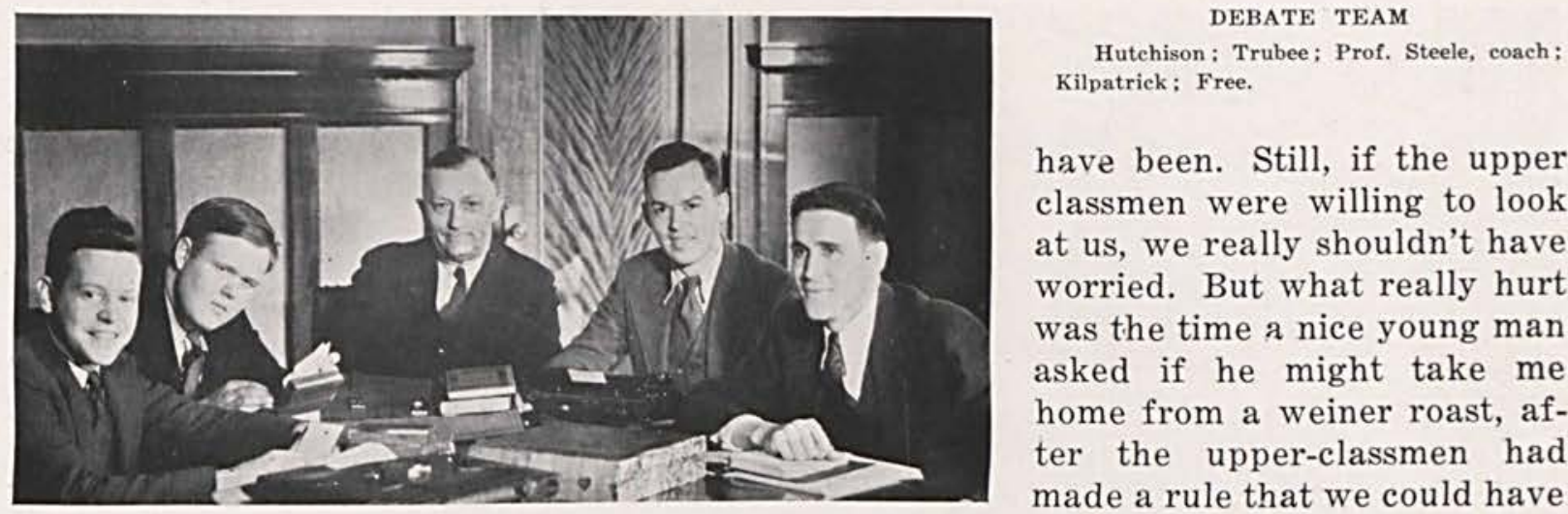

have been. Still, if the upper classmen were willing to look at us, we really shouldn't have worried. But what really hurt was the time a nice young man asked if he might take me home from a weiner roast, after the upper-classmen had made a rule that we could have no dates!

"Yesterday, we girls had to braid our hair, and carry our books to class in a wastepaper basket, with an alarm clock tied around our necks. If anyone could have acted with poise that day, she would have been different from any of us. It was very embarrassing to have your alarm clock break up serious class discussion by starting to ring right in the recitation period; but that often happened, because some upper class fellow usually managed to set the alarm while we weren't looking.

"When Friday came, every freshman breathed a sigh of relief to think that the torture could last only a few hours more. But we soon learned that these last few hours were to be the worst of all. When it was nearly noon, and we believe everything to be finished, someone remarked that the steps of Old Main were covered with dirt. Then we had to bring buckets of water, and scrub and sweep, and we believe everything to be finished,

Finally everyone made a rush to the cars, to go to the tug-of-war, out at Willow Bend. I would like to tell you baout that but I have run out of words."

A somewhat similar story was told to the friends of a freshman boy who was also attending Cedarville College. His story ran thus: "Why you'd think we were less than human and had no right to inhabit the same world as the upper classmen. They look down on us as though we were ants crawling under their feet.

"Just the other morning when I went to College Hall I found several upper classmen sitting on the steps. Several of them made wise (?) remarks, but one in particular spoke in a high rasping voice 'Hello girls, do you think it will rain?' How do they expect us to act dignified when they are forever riding us?

"We are required to be very respectful toward all upper classmen besides obeying all the harsh rules they have made for us. They made us wear our clothes backwards and walk backwards on the campus-rather unhandy and awkward when we were in a hurry. Some of the Freshmen didn't obey all the rules; now that this long drawn-out week is over, I am thankful I did, because those that were considered to be the poor sports and others too who just happened to fall into the hands of certain upper classmen were given a dainty hair clipping which will probably mar the looks of their heads for whole semester.

"Yesterday, Friday, we had to push a sled, loaded with gangs of upperclassmen, all over the football field, while some big fellows back of us helped us along (with heavy paddles in their hands) if they felt we weren't moving fast enough to suit them. Then we were told to go to Willow Bend, a mile or two out of town, where we again received the worst end of the deal. This was the famous Tug-o-War which, I am sad to say, we lost.

"This is college life, though, and if we learn to take it on the chin now, we'll be better able to face life with the same good spirit." 


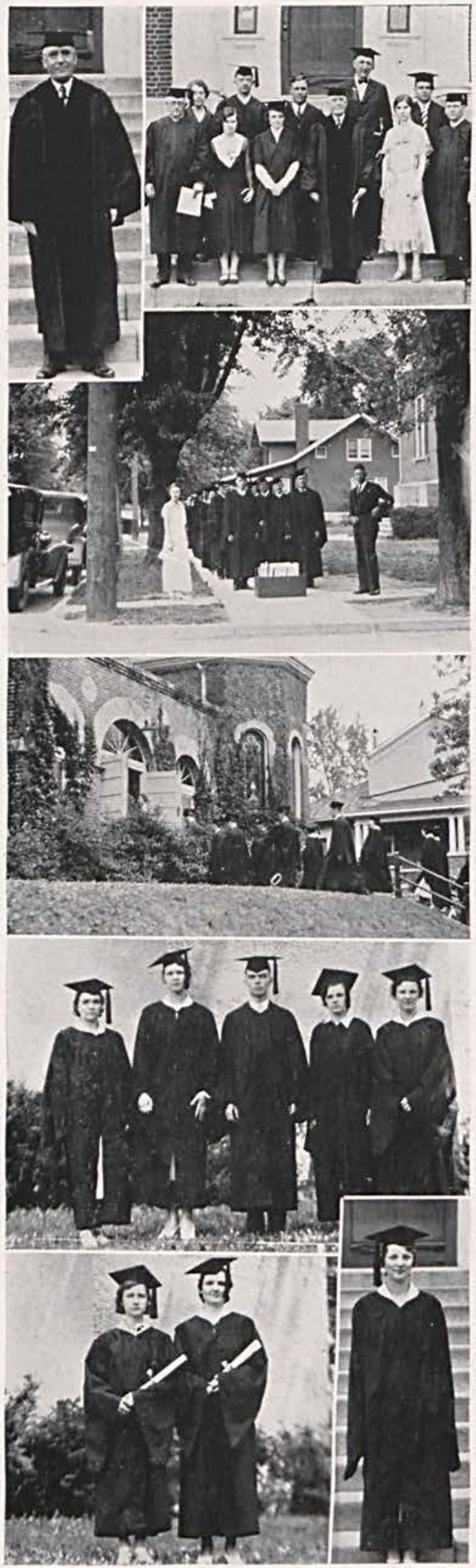

\section{Hallowe'en}

Amid the conglomeration of autumn leaves, clanking chains, fodder, and ghosts, we entered the Alford Gym by a roundabout way on that most fearful of nights, hallowe'en.

People from all walks of life, from bums to royal ladies, put in their appearance.

While it was still rather dimly lighted, we had a relay race in which each one hd to hold in his hand the various organs and "innards" of a departed ghost, including such things $\mathrm{s}$ eyes (oysters) and a stomach (putty).

Then lights came on, and the grand parade started, with the awarding of prizes for the best costumes. After the cermony, the guests unmasked, and spent the rest of the evening playing traditional hallowe'en games.

The evening closed with the ever welcome hallowe'en eats: apples, cider, doughnuts, and candy corn.

\section{Cedrus Play}

On November 22, 1932, "Green Stockings," written by A. E. W. Mason, was presented by the Cedrus Staff as their annual dramatic production.

"Green Stockings is a very clever comedy based on the old country custom that an elder sister wear green stockings at the wedding of a younger sister if that younger sister has captured a husband first. Celia Farady (Jane West) had already worn the green stockings to two weddings and it seemed that she was going to have to wear them the third time as her youngest sister (Lois Cultice) was very much enamoured with the young office seeker, Robert Tarver (Clyde Hutchison). But Celia suddenly decided that she had been pitied and patronized and looked upon as old and ugly and dowdy and dull long enough, and suddenly announced to the family that she had a sweetheart of her own, a Colonel John Smith-pet name, Wobbles. The attitude of her family changed at once and when, after eight months, the announcement of Smith's death appeared in The Times they were greatly shocked and grieved over Celia's apparent loss. When a real John Smith (Joseph Free), having actually received her first love letter which she though she had burned, but which really had been mailed, appeared on the scene, matters became 
decidedly complicated. But during a very brief acquaintance of a few hours they discovered that fate had intended them for each other, and all ended happily.

Jane West, in the leading role, interpreted a difficult part to the complete satisfaction and admiration of the audience. Playing opposite Jane was Joe Free as Col. Smith, and with Joe's military bearing and manly dignity, and Jane's striking personality, they made a very attractive couple indeed.

Marjory Gordon, Eleanor Bull, and Lois Cultice as the utterly selfish and sophisticated sisters of Celia, played their parts in a very capable manner. Aunt Ida, Celia's faithful ally and confidante, was played by Nina Stevenson. This was a difficult part and Nina handled it very successfully.

You wouldn't think that one with the in telligence with which Clyde Hutchison seems to be endowed could play so well the part of and empty headed young English swell. Robert Tarver, Clyde got a laugh with every line.

Wm. Faraday, the father, always depending upon Celia to anticipate his every want was played by Homer Murry. Others in the cast were Walter Kilpatrick as the testy retired admiral, Art Donaldson and Charles Bost as Raleigh nd Steele, old friends of the family, who suddenly decided that Celia was not so "bad looking"; and Preston Garlough, as the efficient butler, Martin.

"Green Stockings" was directed by Glenna Basore.

The Wilberforce Male Quartette, a song and dance act by Rachel Douthett and Pat Crawford and Duffy's Orchestra, furnished entertainment between acts.

\section{Junior Play}

The Junior Class under the direction of Glenna Basore presented "Pineville Meets the Prince," a three act comedy by Watkins E. Wright, in the Cedarville Opera House on March 7. Due to the bank holiday the audience was small but nevertheless very appreciative.

The story of the play is that of the young prince of Dalvaria who was brought by his mother to her old home town in Pineville, Virginia where she expected to find for him a rich wife among the daughters of her formerfriends. Prince D'Auby's father had died leaving the estate in Dalvaria in a run-down condition, so Claire's scheme was to find a wife for Peter who would have enough money to repair the Dalvarian castles. On arriving in Pineville and meeting lovely girls and men of his own age who worked and talked of fruit. growing, real estate and newspapers, Peter felt ashamed of having come in search of a rich wife. Peter, therefore, determined to prove himself more a member of "Rotary" than of "Royalty." How he does this, how his mother tries to marry him off, how he wins the girl of his choice, and how his mother turns to the sweetheart of her girlhood, all combine to make a play in which comedy, romance, andrama are blended.

Our popular cheer leader, Edward Tedrick, proved himself to be very capable of handling the leading role, as the prince. Doris Hartman is at home on the stage in any part, and was especially so in that of Claire D'Auby, the scheming mother.

Robert Ross was very affable as the family lawyer and old sweetheart of Claire. Lois Cultice was clever in the part of Anne Jones, the efficient stenographer, who was able to make herself very unattractive or attractive equally as well as the occasion demanded.

Margaret Berk as Mrs. Jeffries, and Ruth West as Mrs. Prentice, very skillfully played the parts of the mothers who were very desirous of having the prince elope with their respective daughters, Lucy and Peggy, played by Jane West and Wilda Auld. Nina Stevenson brought many a laugh through her interpretation of Cassie, the colored maid. Jef- 


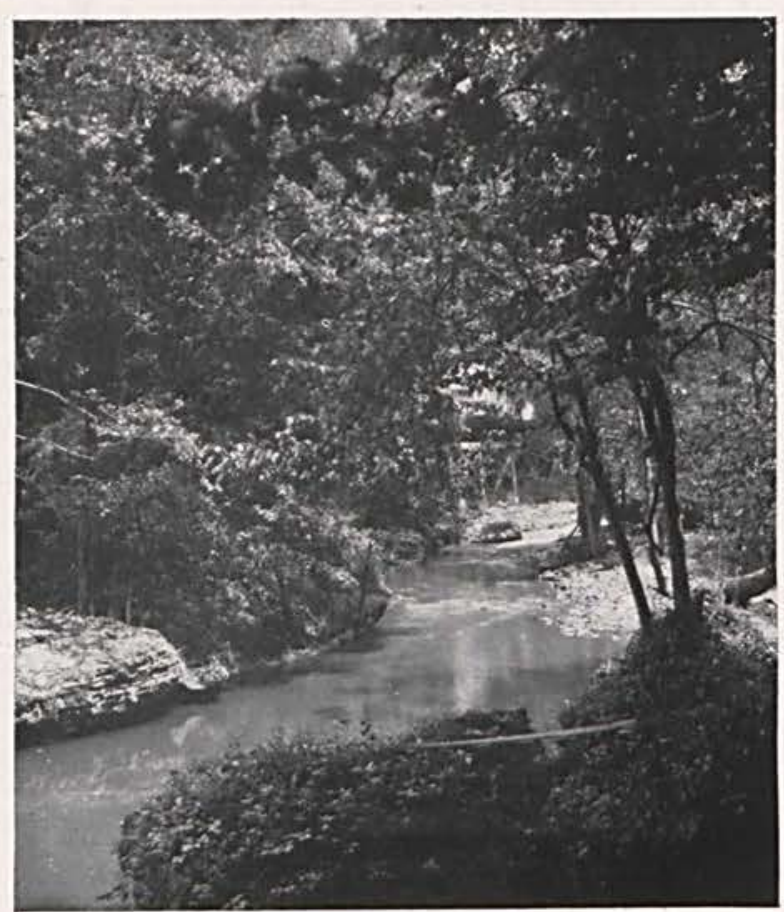

Robert Bennett, trying to tell "the truth, the twenty-four hours, would have made the play assisted by his two friends, Dick Donnely (Ed were constantly arranging situations in whichit hero to tell the truth. Howeve, he won his bet.

Much of the success of the play was ow ed to Miss Basore, the director. We must also remember the good music furnished by Duffy's orchestra of South Charleston.

The cast of the play was as follows:

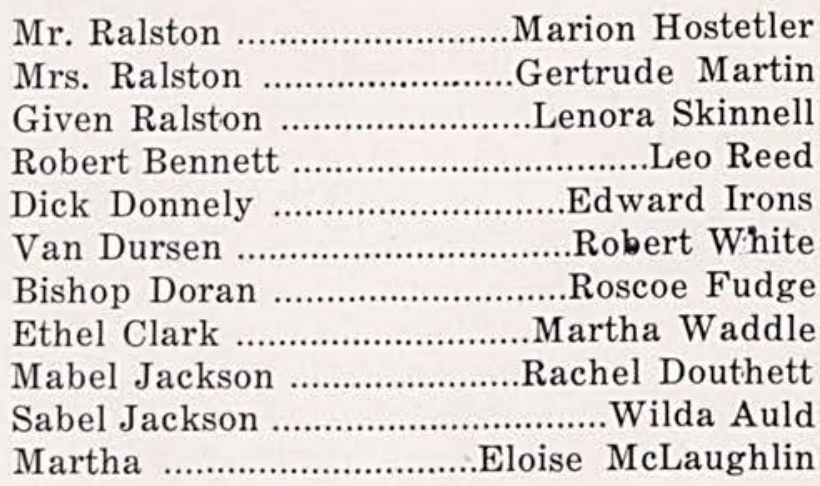

\section{Cedar Day-1932}

It was early in the morning of June 1, 1932. The stage and throne were beautifully bedecked with flowers. Cars came rolling over the college campus, and Cedar Day activities were about to begin. Suddenly, the sun ceased to shine, and in a little while rain was pouring over the beautiful decorations and the stage. Rarely, if ever, have we had our 
Cedar Day program hindered by rain. However, the unprecedented had happened. What were we to do?

Finally, the crowd and performers were transferred to the gym, and the program began. It was a well-planned program. First, Rachel Douthett, our charming queen, entered with her attendants, and the whole procession of performers followed. After she had been crowned by last year's queen, Sarah Rumbaugh, and was seated on her throne, the Maypole dance was performed for her. In spite of the wet streamers and the wobbly pole, upheld by some sturdy athletes, the dance was executed very creditably.

The theme song of the program, "As Time Goes By," was sung by Eleanor Bull. In portraying this theme, several ages were represented by dance and song.

First, group of costumed dancers portrayed the Greek Age by a graceful moon dance. The part of Luna was taken by Marjorie Gordon, solo dancer.

Then the Elizabethan Age was represented by Jane West, the lady, and Doris Hartman, the man, in "A Rainy Day Flirtation."

The Early American Age was depicted by a group of Indians who danced and sang "The Land of the Sky-Blue Water."

The Modern Age was represented by the gym class as they performed various exercises and stunts including most cleverly built pyramids.

A Future Age was represented by tiny Margaret Borst in a solo dance.

At the conclusion of the performance the queen and her attendants descended from the stage and followed the performers from the scene.

The orator of the day was Marion Hostetler. Marion delivered a most inspiring oration on the subject of "Paints."

The program was well attended, the gym being crowded by a capacity audience.

\section{COLLEGE CLUB}

One of the most prominent places at the noon hour any day is the College Boarding Club. This is located in the basement of the Library, opposite the literary hall. Here the non-resident students may board as a group, and enjoy the friendships which make for truly pleasant student associations.

The club is fortunate in having such an able manager as Mrs. Morton. She chooses excellent cooks and prepares good food.

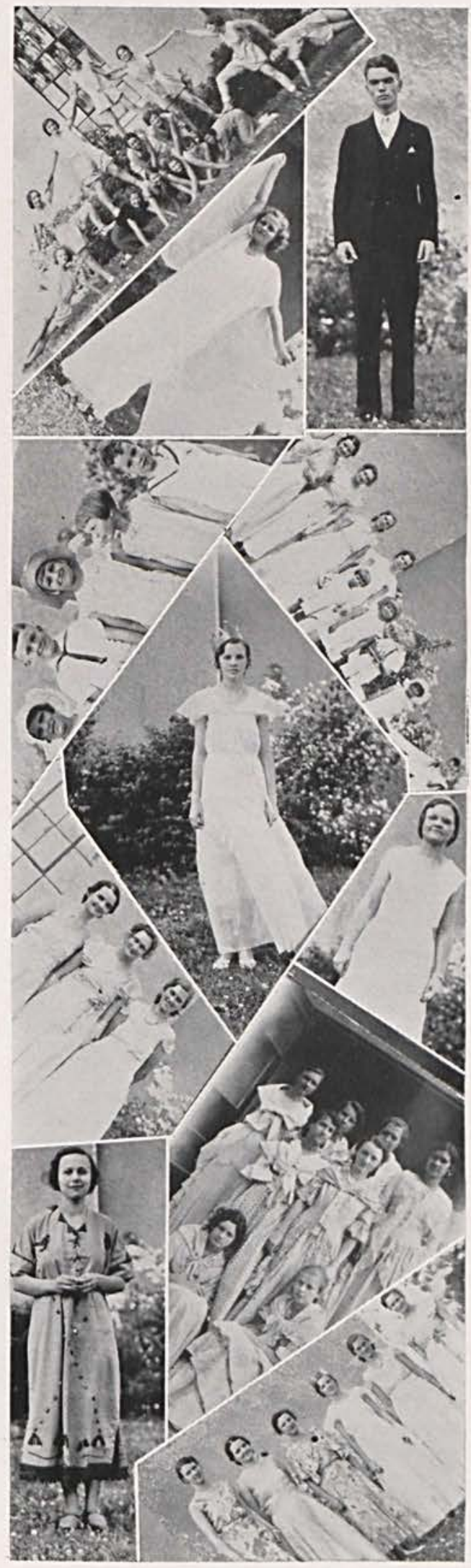




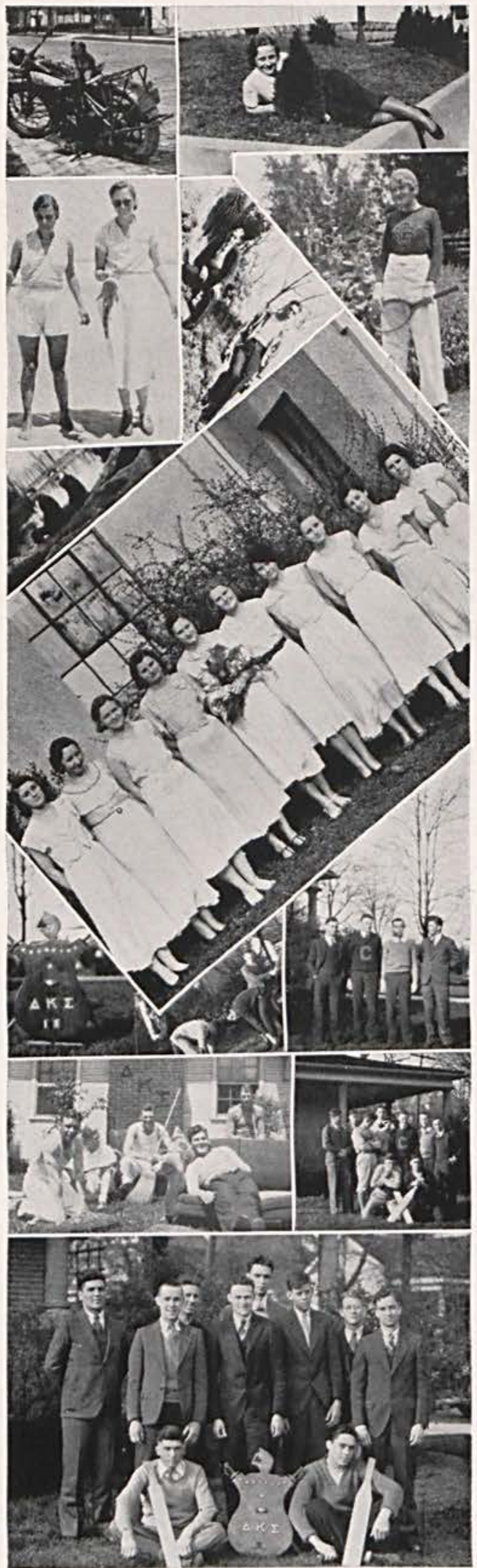

The club is run on a non-profit basis and provides the students with a real meal for a nominal sum.

At the club many tall stories originate and end. If you haven't learned the trick of tieing chairs together, or kidding our steward, Preston Garlough, about his "Sir," you haven't qualified for your membership at the club.

\section{The X Club}

The X Club was organized in 1931-32. Its members are residents of Xenia. The purpose of the club is to create interest among the Xenians in Cedarville College.

This year the following officers have served:

President Charles McNamee

Vice President................W. B. McCallister

Secretary .......................Dorothy Lunsford

Treasurer ............Mary Catherine Probasco

The club was composed of twelve members this year. Several feeds and parties were held, together with occasional luncheons at the Cedar Inn.

We hope that the " $\mathrm{X}$ " Club will continue in the years to come, and strive to create an interest for Cedarville College among thle students of Xenia High school.

\section{The Touch of the Master's Hand}

'Twas battered and scarred, and the auctioneer Thought it scarcely worth his while To waste much time on the old violin, But held it up with a smile-

"What am I bidden, good folks?" he cried, "Who'll start the bidding for me?

A dollar, a dollar, now two, only two?

Two dollars and who'll make it three?

Going for three"-but no,

From the room far back a gray-haired man

Came forward and picked up the bow.

Then wiping the dust from the old violin And tightening up all the strings, He played a melody pure and sweetSweet as an angel sings.

The music ceased and the auctioneer With a voice that was quite and low Said "What am I bid for the old violin?" And he held it up with the bow. “A thousand dollars and who'll make it two? Two thousand and who'll make it three? Three thousand once, three thousand twice, 
And going-and gone," said he.

The people cheered and some of them cried, "We do not quite understand

What changed its worth." Swift came the reply,

"The touch of the master's hand."

And many a man with a life out of tune

And battered and torn with sin

Is auctioneered cheap to a thoughtless crowd, Much like the old violin.

A mess of pottage, a glass of wine,

A game, and he travels on.

$\mathrm{He}$ is going once, he is going twice,

$\mathrm{He}$ is going-and almost gone-

But the Master comes, and the foolish crowd Never can quite understand,

The worth of a soul and the change that was brought

By the touch of the Master's hand.

- Myra Brooks Welch.

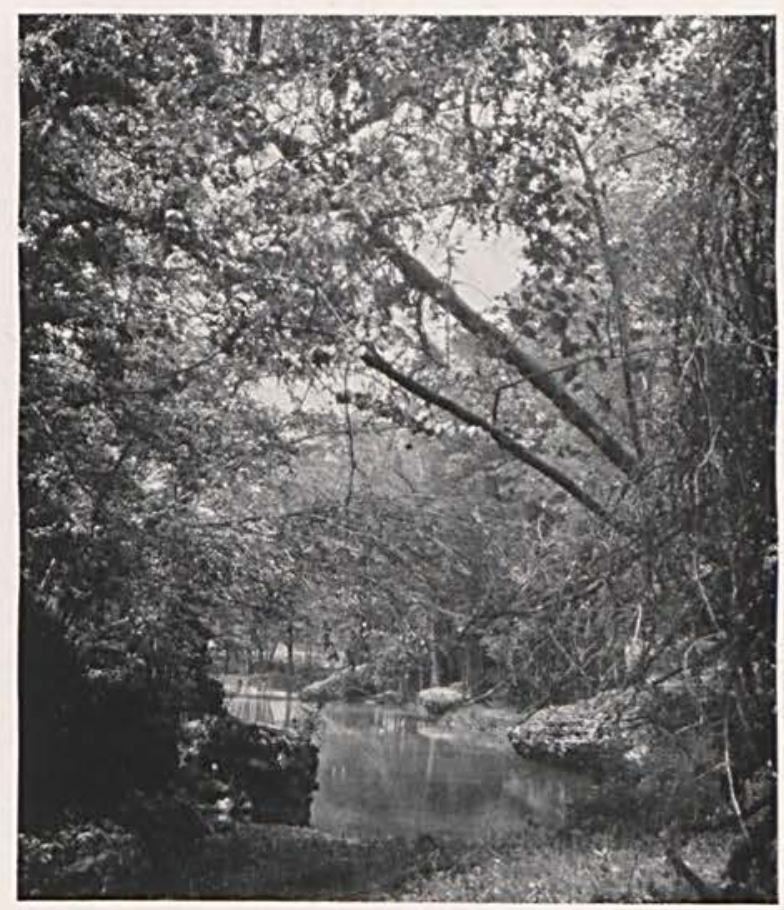

\section{The Fountain of Good Character}

Not one of us begins with a character. Each man must build his own house of personal character. It does not exist until he has brought efforts to bear in the organization and coordination of materials provided. What we have are impulses, instincts, tendencies, and sentiments. Until these are organized and regulated, we have no character.

The strong character is that which is able to subdue these tendencies, impulses, sentiments, under the domination of some motive; the good character is that of the man whose dominating motive is a good one. The weak character is that which is deficient in the organzing, coordinating power. Character may be strong without being good. A man might marshal all his powers under the dominating motive of money-making, and he might be very strong, and very successful in the worldly sense, and it is quite possible that his success would remain with him to the end of his days. He might even die a millionaire. Nobody would call him a weakling; he certainly would have had strong character. Or perhaps his dominating motive was power; he had the ruling passion. He made all his raw material of character, so to speak, subserve that purpose. Wonderful success may have attended the effort. Here, again, there was strong character. It may not have been good, it may have been tyrannical and despotic, but there is no doubt about its strength. Here are two types building character without God, that, without reference to the highest, without giving any religious consideration a controlling place. Can it be said, then, that these men build character in vain?. They achieved pretty well what they set out to achieve; the man meant to make money and he made it; he meant to have power and he got it; the building has not been in vain from that point of view at all. It has only been in vain in view of the higher possibilities in each case. By a worldly standard each of these two men has been eminently successful. But measured by the higher possibility of human nature, these men are failures-the rich man is poverty-stricken, the powerful man is a weakling. Measured by a spiritual standard the despot is a slave, the tyrant is 


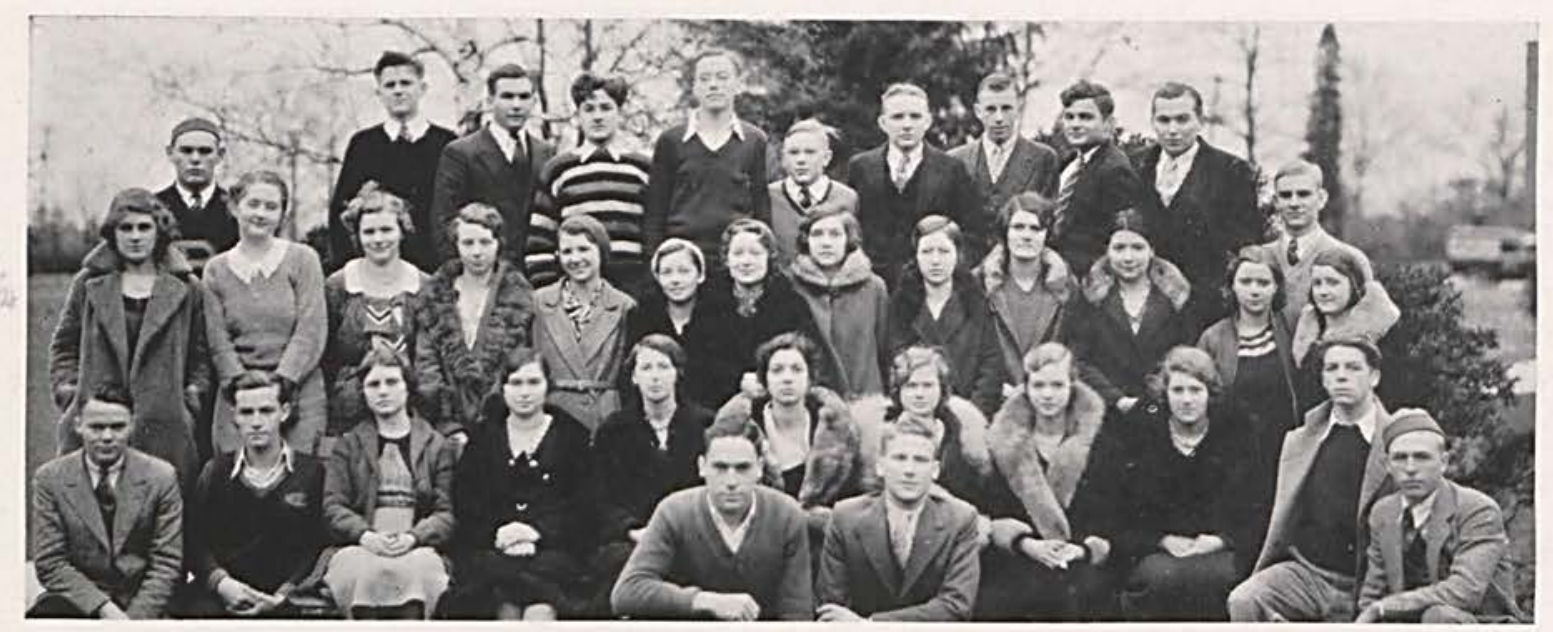

\section{FRESHMA N CLASS}

First row: Miller, W. Reid; Second row: Thompson, P. Reed, Knoop, Labig, MeCallister, Robe, Henry, Hostetler, Watson, MeKnight. Thomas: Third row: Chenoweth, Wham, Turnbull, Corry, Corbin, Bradley, Coulter, Guthrie, Bisdorf, Dean, O. Brill, M. MeLaughlin, M. Linton: Fourth row: MeHenry, Meyers, R. Murray, Cappola, Glass, Buehler, W. Linton, V. Garlough, Fox, Ensign, Chamberlain.

under the wheels of his own chariot, and the man who has set his heart upon riches is denied the kingdom of heaven.

Character cannot be built successfully without God. By this we do not mean that he must accept some theological formula which we or somebody will draw up, or which some Church may prescribe. We mean only that he cannot build a true and noble character except by reference to universal ends, and with the help of a power which is more than his own. To build the house of character around anything which is merely personal, or individual, or indeed anything less than universal is to fail to build the best. "Except the Lord build the house, they labor in vain that build it."

Psychologists point out to us that an act of will in favor of a higher impulse somehow secures an influx of energy that enables it to triumph. There is general agreement that in itself the ideal impulse is weaker than the coarser desires of our nature. And yet we know that if we turn an effort of will upon that ideal impulse, and at the focus of consciousness, what it urges, we may attain a great victory over the coarser desires. Certainly that is how character grows up. But from where does the influx of energy with which to enforce the ideal impuse come? Many psychologists say that self-respect is a great saving force, but it will not account for good character. A man who has acquired admirable moral sentiments may yet become an habitual drunkard. He may still desire the realization of all that is good and moral, and may have a lofty ideal of conduct, but if he has become known to all the world as a sot, and has become aware of the fact, no longer can he find in his self-regarding sentiment a support for his better, more ideal motive. The Salvation Army can point to thousands of cases where men were habitual drunkards and habit-

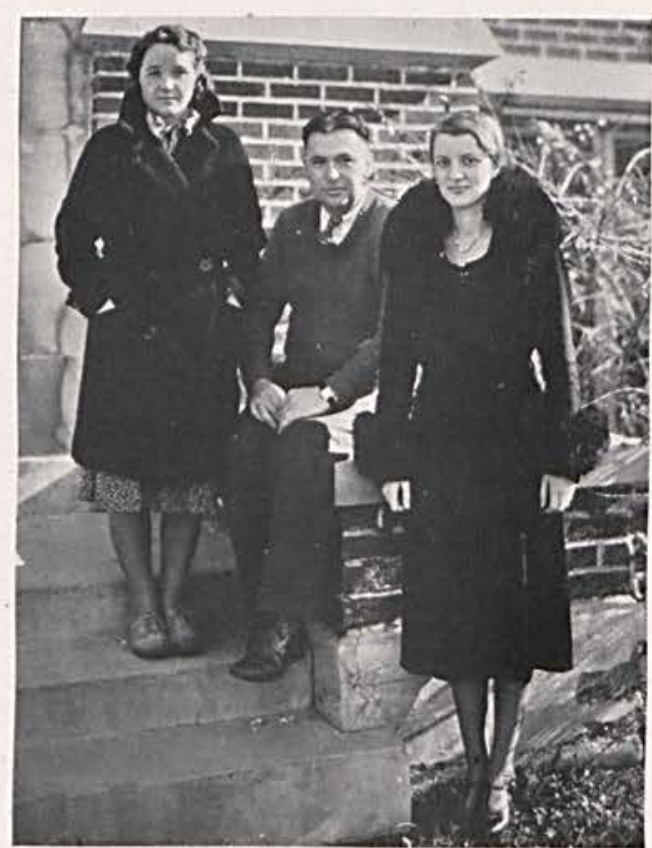

SPECIAL STUDENTS Auld, James, Waddle 
ual thieves, and habitually bad in other respects, and all their neighbors knew it, and they knew that their neighbors knew it, and yet those men have been reclaimed. The ideal impulse somehow arose in their hearts, and somehow it was reinforced sufficiently to break the tyranny of all the old habits.

Good character must look for its source to Life, that timeless eternal Life, which we call God. When we have read the most useful psychology and philosophy of character building-which of course is a very wise thing to do-we come back, with a feeling of great satisfaction, to the simple but profound religious position that the good which springs up within us is the movement of the Divine Spirit, the uprising of the life of God. And if we seize upon that, and give ourselves to it, power will come, and more power, enough to conquer, and enough even to be more than conquerers.

When a man sets himself to acquire character by an act of will, when his dominating motive transcends any mere individual interest or advantage, when the acquirement of spiritual quality is supreme in his mind, his life fills up from the eternal sources as a well fills up from the springs.

It is true to say that in one sense the well is only so many feet deep, but in another sense it is as deep as the world; however much you draw water from it, it constantly refills, because, in the last analysis, it is in communication with all the moisture of the world. The well may be in your back garden, but the Atlantic Ocean, the Pacific Ocean, and every ocean there is, helps to keep it full. The sun draws water from the ocean, and the clouds bring it back to earth, to feed the springs that fill the well. The soul of a man is something like that. It is in communication with infinite resources of spiritual power; it is upon these resources that it draws in the making of character. To have learned from experience is the finest guaranty of moral victory. When good character is built, man himself is the builder; but through him another Builder, without Whom there can never be true success, is operating.

-Rev. R. W. Ustick,

Pastor of First United Presbyterian Church of Springfield, Ohio. Alumnus of Cedarville College.

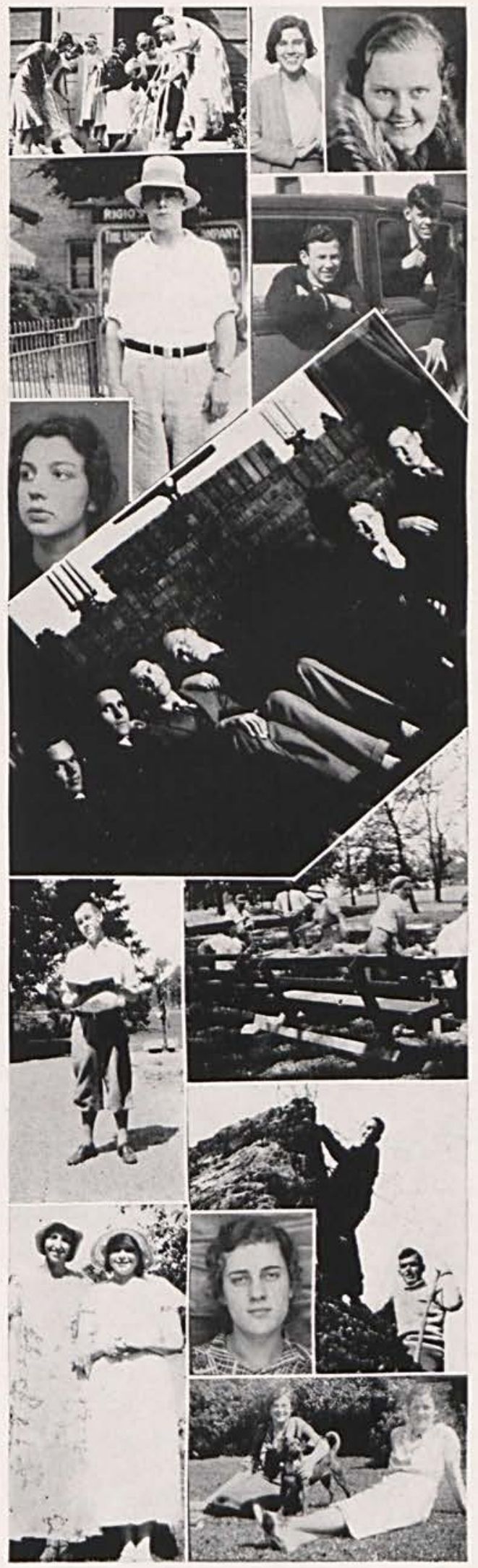




\section{Special Students}

A number of special students and post graduate students have been attending the college this year. Several who graduated from the school last year are completing another full year's course, while several others are doing part time work.

Special students whose photographs do not appear in this book are Edna Hanna,, Esther Mae Hartman, Robert Wilson, Rev. C. A. Hutchison, and Ruth West.

\section{Advertisers}

We wish to extend our sincerest thanks to those who have placed advertising in this book. Through their cooperation and financial aid we have been able to publish a better book than would have otherwise been possible. 


\section{CROUSE'S}

Seventy-five years ago, the country store, with its counters full of every type of merchandise, could carry only a limited supply of groceries. Today, the middleman's business has kept pace with the division of labor as practiced in every other industry, and the country groceryman must compete with his city neighbor in the variety and quality of the produce he handles.

Crouse's Grocery Store extends its sincerest greetings to an everprospering Cedarville College.

\section{CEDAR INN}

"The way to a man's heart is through his stomach. "A restaurant in a college town has special opportunity to build up a reputation for quality meals, for students away from home are the most particular of connoisseurs. An excellent variety of well-prepared foods, attractively served in a homelike atmosphere, makes a most pleasing impression on the customer.

The new management of the Cedar Inn, catering especially to the Cedarville College students, congratulates that institution upon the completion of a most successful school year.

\section{CEDARVILLE HERALD}

On April 12, 1709, Richard Steele wrote the first letter of the famous "Tatler" series, turning into literature the happenings of the day. As a prefatory comment, he quoted this couplet:

"Whate'er men do, or say, or think, or dream, Our motley paper seizes for its theme."

Though the pofession of journalism has advanced far since that day, the newspaper of today must still keep that motto in view as it seeks out the news of the times, and aids the community in the formation of local policies.

For many years, Cedarville community has been served in this way by the Cedarville Herald.

\section{MASTERS'}

The type of service that can be rendered only by neighbors is the kind you find in the country store of today. The storekeeper is willing to go out of his way to see that his customer is well cared for, and he realizes that any added expense he incurs in this way is amply repaid in added trade and in the spirit of neighborliness that results in this community. So he lines his shelves with every ty pe of high quality food, and prepares to prove himself a friend as well as a business man.

Master's Grocery Store wishes Cedarville College success. 


\section{CEDARVILLE COLLEGE}

Dedicated to the promotion of the word and will of Gbd, Cedarville College stands today, as it stood for thirtynine years, for the presentation of a sound Christian liberal education to its students. Economy and sacrifice make it an inexpensive school; the tenets of its faith make it a safe pace for the youth to spend the formative years of his early maturity; the quality of its faculty and the type of young people attending Cedarville College enable the student to form contacts and friendships that remain his most valuable memories throughout life. 


\section{STANDARD ICE CREAM}

In the heat of summer, no other food can possibly taste as good as a dish of cool ice cream; and if added to this pleasure is the knowledge that the refreshing dish was prepared under the most sanitary of conditions, in an up-todate factory, under rigid inspection regulations, the results are even more satisfying.

For many years, Standard Ice Cream has been the standard in central Ohio, for its quality and for the sanitary conditions under which it is made alike. Its reputation in Cedarville College is well deserved, and has been maintained through many successive college "generations" of students.

It is available only at Richards's Drug Store, by the bridge. 


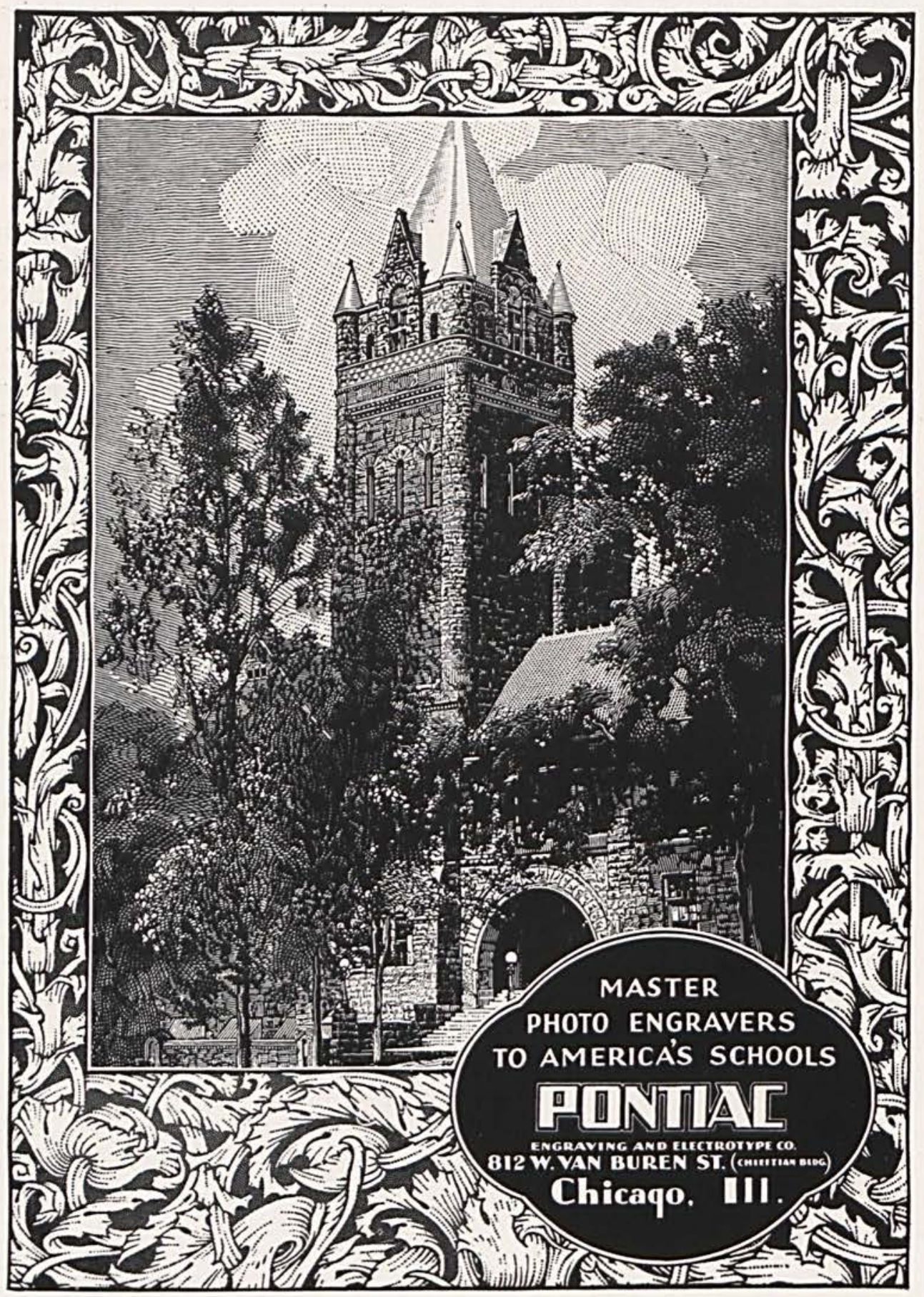




\section{RECO'S}

"All work and no play makes Jack a dull boy." Young people in college life find many interests to hold them, and they must secure their recreation largely in intra-mural and inter-collegiate sports. Basketball, baseball, tennis, football-all offer fine training in team-work and good sportsmanship. For the fullest enjoyment of these sports, fine equipment is essential. We are proud to offer our store as the informal headquarters for Cedarville students while in Springfield. Reco's Spirting goods, 16 West High Street.

\section{McNAMEES}

As we throw lumps of coal into our modern stoves, we seldom pause to realize the miracle that has taken place to produce this fuel. Millions of years ago, where vast fields of coal are located today, a dense foliage covered the land. The accumulations of years of this growth, buried under later vegetation, became carbonized by this pressure and the heat of the sun. If the land was marshy and low,bituminous coal was produced; in mountainius regions, we find anthracite.

McNamee's Coal and Supply Company, Xenia, congratulates Cedarville College and the Cedrus Staff on the completion of this book. 
Autographs 

s. 

